


\section{DISTRIBUTION OF ANTHROPOGENIC FILL MATERIAL WITHIN THE Y-12 PLANT AREA, OAK RIDGE, TENNESSEE}

G. E. Sutton Jr. S. M. Field

\section{EEC 19198 \\ OSTI}

October 1995

DISTRBUTON of the Dowh

Prepared for the

Environmental Management Department

Health, Safety, Environment, and Accountability Organization

Oak Ridge Y-12 Plant

Oak Ridge, Tennessee 38731

\title{
MASTER
}

managed by

LOCKEED MARTIN ENERGY SYSTEMS, INC. for the

U.S. DEPARTMENT OF ENERGY

under contract

DE-A C05-840R21400 


\section{DISCLAIMER}

This report was prepared as an account of work sponsored by an agency of the United States Government. Neither the United States Government nor any agency Thereof, nor any of their employees, makes any warranty, express or implied, or assumes any legal liability or responsibility for the accuracy, completeness, or usefulness of any information, apparatus, product, or process disclosed, or represents that its use would not infringe privately owned rights. Reference herein to any specific commercial product, process, or service by trade name, trademark, manufacturer, or otherwise does not necessarily constitute or imply its endorsement, recommendation, or favoring by the United States Government or any agency thereof. The views and opinions of authors expressed herein do not necessarily state or reflect those of the United States Government or any agency thereof. 


\section{DISCLAIMER}

Portions of this document may be illegible in electronic image products. Images are produced from the best available original document. 


\title{
DISTRIBUTION OF ANTHROPOGENIC FILL MATERIAL WITHIN THE Y-12 PLANT AREA, OAK RIDGE, TENNESSEE
}

\author{
Prepared by: \\ G. E. Sutton Jr. (1) (2) \\ S. M. Field (2)
for the
Environmental Management Department
Health, Safety, Environment, and Accountability Organization Oak Ridge Y-12 Plant
Oak Ridge, Tennessee 37831 \\ managed by \\ LOCKHEED MARTIN ENERGY SYSTEMS, INC. \\ for the \\ U.S. DEPARTMENT OF ENERGY \\ under contract DE-AC05-84OR21400
}

(1) Department of Earth Sciences, Tennessee Technological University, Cookeville, Tennessee

(2) Oak Ridge Institute for Science and Education, Oak Ridge, Tennessee 
George E. Sutton Jr., Tennessee Technological University, is a participant in the U.S. Department of Energy Professional Internship Program administered by the Oak Ridge Institute for Science and Education (ORISE). The investigation described herein and the resulting report were sponsored by both the Environmental Sciences Division at Oak Ridge National Laboratory (ORNL) under the direction of Dr. RaNaye B. Dreier, and the Groundwater Protection Program (GWPP) at the Y-12 Plant under the direction of Kevin Jago.

\section{Acknowledgments}

The authors are grateful to the following individuals for their many helpful comments, suggestions, and assistance during this study: Kevin Jago, Y-12 Plant GWPP; Dr. RaNaye B. Dreier, Environmental Sciences Division, ORNL; staff of the Y-12 Plant GWPP, in particular Steve Jones, for assistance with engineering documents and reports; and $\mathrm{K}-25$ Site engineering staff. 
CONTENTS

Section $\quad$ Page

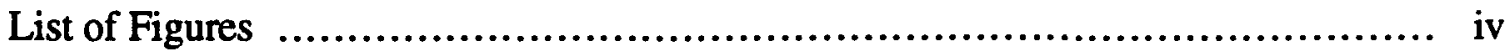

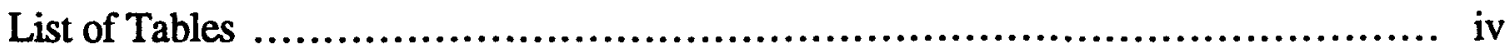

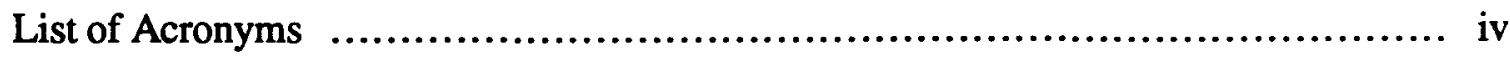

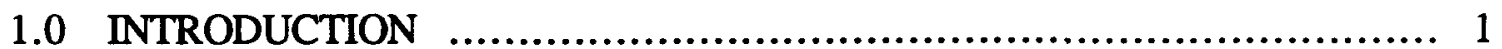

2.0 METHODOLOGY ..................................................... 2

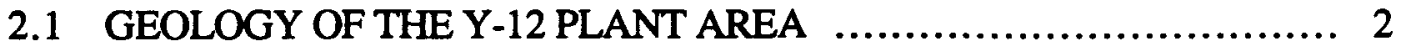

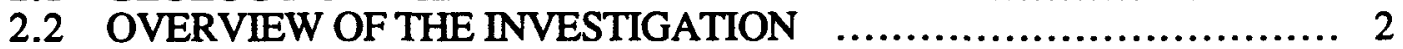

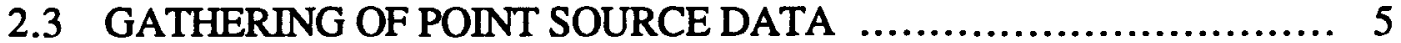

2.4 POPULATION AND EXPLANATION OF DATA TABLE FIELDS $\ldots . . . .5$

2.5 METHOD OF CONTOURING OF POINT SOURCE DATA ............. 9

2.6 UTILIZATION OF DEFINED CUT AND FILL ZONE MAPS .......... 9

2.7 UTILIZATION OF TOPOGRAPHIC MAPS ........................... 9

2.8 UTILIZATION OF AERIAL PHOTOGRAPHS ….......................... 9

3.0 RESULTS, OBSERVATIONS, AND INTERPRETATIONS $\ldots \ldots \ldots \ldots \ldots \ldots$

3.1 MAJOR FILL ZONES WITHIN THE Y-12 PLANT AREA $\ldots \ldots \ldots \ldots \ldots . .10$

3.2 INTERPRETATION OF FILL ZONES $\ldots \ldots \ldots \ldots \ldots \ldots \ldots \ldots \ldots \ldots \ldots$

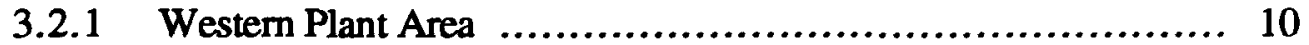

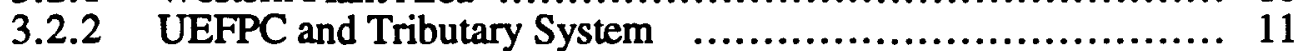

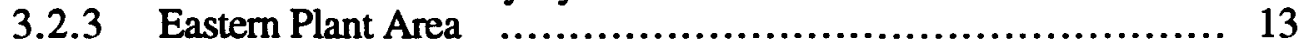

$\begin{array}{llll}3.3 & \text { POTENTIAL IMPACTS ON CONTAMINANT DISTRIBUTION } \ldots . . . & 13\end{array}$

4.0 SUMMARY AND RECOMMENDATIONS F............................ 17

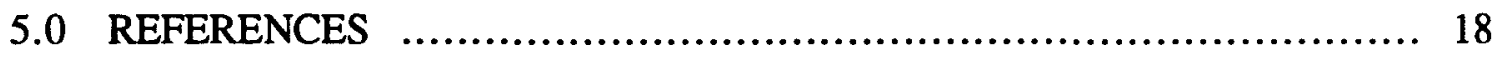

APPENDIX - Tabulation of Monitoring Well and Soil Boring Point Source Data

PLATE 1 - Fill Thickness Map of the Y-12 Plant Area 


\section{LIST OF FIGURES}

Eigure

Page

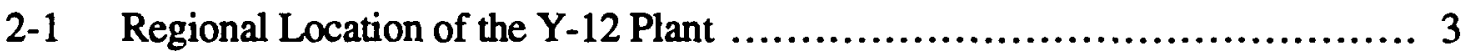

2-2 Topography and Bedrock Geology of the Y-12 Plant Area ................... 4

2-3 Y-12 Plant Anthropogenic Fill Study Area Boundary $\ldots \ldots \ldots \ldots \ldots \ldots \ldots \ldots$

3-1 Nitrate in Groundwater in the Upper East Fork Poplar Creek

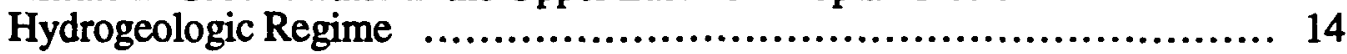

3-2 VOCs in Groundwater in the Upper East Fork Poplar Creek Hydrogeologic Regime

\section{LIST OF TABLES}

Table

2-1 Contractor Identification Prefixes for Soil Boring Point Source Data 7

\section{LIST OF ACRONYMS}

GIS - Geographic Information System $\mathrm{mg} / \mathrm{L}$ - milligrams per liter UEFPC - Upper East Fork Poplar Creek $\mathrm{ug} / \mathrm{L}$ - micrograms per liter VOCs - volatile organic compounds 


\subsection{INTRODUCTION}

Widespread groundwater contamination in the vicinity of the Oak Ridge Y-12 Plant has been documented through a variety of monitoring efforts since the late 1970s. Various contaminants, most notably volatile organic compounds (VOCs), have migrated through the subsurface and formed extensive contaminant plumes within the Knox Aquifer/ Maynardville Limestone, the primary exit pathway for groundwater transport within the Bear Creek Valley.

In 1991, an integrated, comprehensive effort (Upper East Fork Poplar Creek [UEFPC] Phase I monitoring network) was initiated in order to (1) identify contaminant source areas within the industrialized portions of the plant and (2) define contamination migration pathways existing between the source areas and the Knox Aquifer/Maynardville Limestone (Geraghty and Miller, Inc. 1990). Data obtained during previous studies have indicated that extensive zones of fill and buried utility trenches may serve as preferred migration pathways. In addition, portions of UEFPC were rerouted, with several of its tributaries being filled during the initial construction of the plant. These filled surface drainage features are also believed to serve as preferred migration pathways. The identification of preferred contaminant migration pathways within the Y-12 Plant area is essential and required to refine the current Bear Creek Valley groundwater conceptual model and to assist in the selection of technically feasible and cost effective remedial strategies.

This report presents the results of an initial investigation of the occurrence of manmade (anthropogenic) fill and its effect upon groundwater movement within the plant area. These interpretations are subject to revision and improvement as further investigation of the effects of the fill upon contaminant migration progresses. 


\subsection{METHODOLOGY}

\subsection{GEOLOGY OF THE Y-12 PLANT AREA}

The Y-12 Plant is located in Bear Creek Valley within the Valley and Ridge Province in eastern Tennessee (Fig. 2-1). Several northwest-trending, southeast-dipping thrust sheets characterize the structure of the region (Hatcher et al. 1992; Fig. 2-2), from which a series of parallel valleys and ridges have formed. Bear Creek Valley is flanked by Pine Ridge to the north and Chestnut Ridge to the south (Hatcher et al. 1992). These ridges serve as the primary sources of recharge for the Upper East Fork Poplar Creek Hydrogeologic Regime (East Fork Regime), within which the industrialized portion of the Y-12 Plant is almost entirely confined (HSW 1994).

Pine Ridge is formed primarily of shale and siltstone strata of the Cambrian age Rome Formation (Fig. 2-2). The strata forming Chestnut Ridge are primarily the dolostones of the Knox Group and are of upper Cambrian to lower Ordovician age. Bear Creek Valley is underlain by limestone and shale formations of the Conasauga Group of middle to upper Cambrian age and overlain by varying thicknesses of unconsolidated material, exceeding $30 \mathrm{ft}$ in some places (Hatcher et al. 1992). Three major joint sets have been identified in the Bear Creek Valley: one set generally trends parallel to bedding planes, a second set that is steeply dipping and trending parallel to geologic strike, and a third set that is also steeply dipping but trends perpendicular to strike (HSW 1994). The Knox Group and Maynardville Limestone of the Conasauga Group comprise the Knox Aquifer; these two units function as a single hydrologic unit (Solomon et al. 1992). The remainder of the Conasauga Group and Rome Formation, in part, form the Oak Ridge Reservation Aquitards (Solomon et al. 1992).

The bedrock in the vicinity of the Y-12 Plant is overlain by varying thicknesses of unconsolidated deposits. The typical soils range from clayey silts to silty clays (IT 1986). Alluvium, colluvium, residuum, and anthropogenic fill are all present, with a typical combined thickness throughout the East Fork Regime of less than $40 \mathrm{ft}$ (Solomon et al. 1992). The anthropogenic fill is of varying composition, with material ranging from reworked silty clay to building construction debris (Appendix). Previous studies of the fill in the Y-12 Plant area showed that during two periods of construction, fill material was deposited in two different layers with void space being found throughout (Solomon et al. 1992). The void space is caused by the variety of sizes and types of fill materials; as a result, the fill is highly anisotropic in regard to hydraulic properties. Detailed review of boring logs (this study) confirm the heterogeneity of fill types.

\subsection{OVERVIEW OF THE INVESTIGATION}

An investigation to determine the extent of anthropogenic zones of fill material and the content of the fill was initiated by the Oak Ridge Y-12 Plant Groundwater Protection Program in May 1995. The identification of fill zones is important as they may serve as preferred migration pathways for groundwater and contaminants from source areas to the Knox Aquifer. The Maynardville Limestone is of particular importance due to the presence of prevalent solution features that allow this unit to function as the primary conduit for groundwater in the Bear Creek Valley (HSW 1994). Also, a number of potential contaminant source areas within the Y-12 Plant area overlie the Maynardville Limestone, making it a prime concern of groundwater investigations. 




Figure 2-1. Regional Location of the Y-12 Plant 


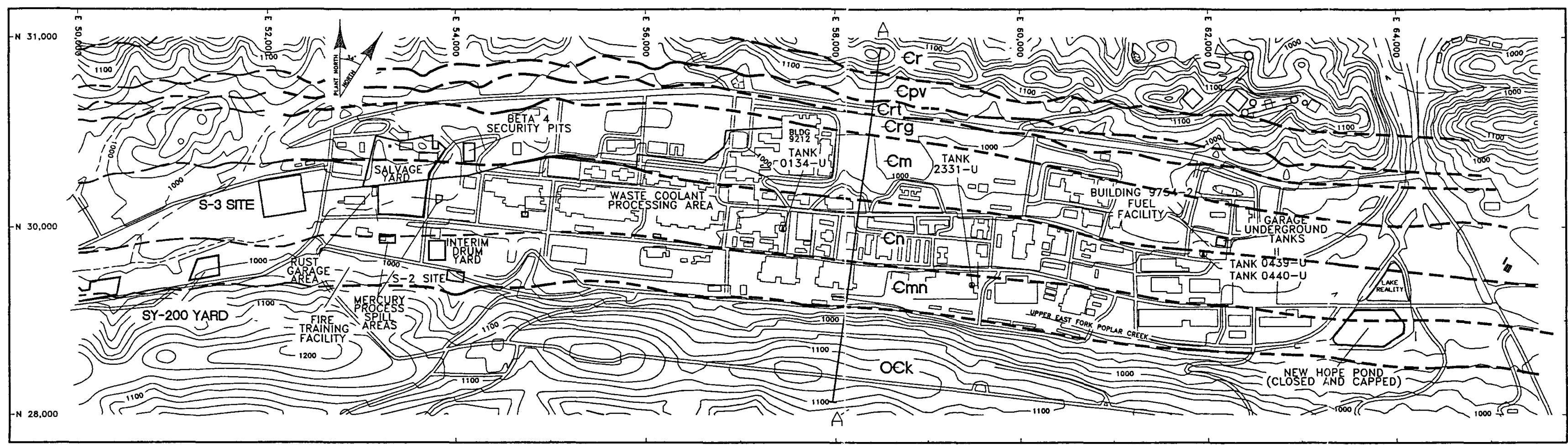

0

2000

SCALE $(f t)$

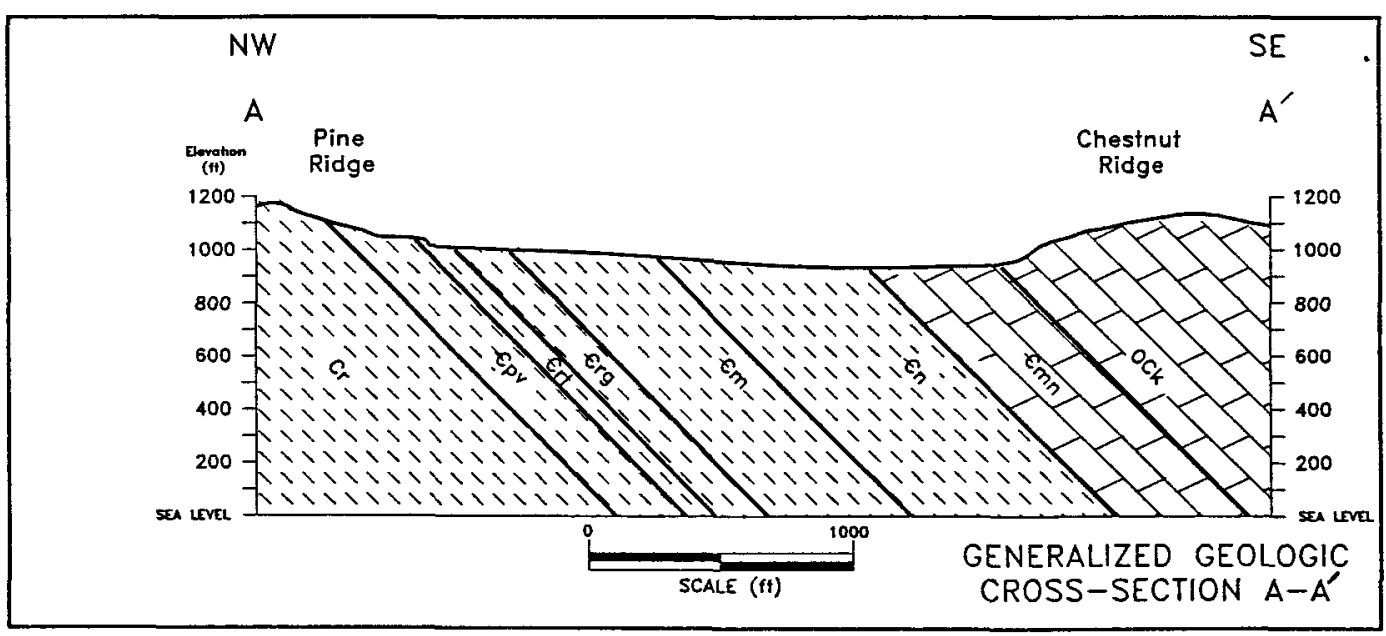

\begin{tabular}{|c|c|c|c|c|c|c|}
\hline \multicolumn{3}{|c|}{\begin{tabular}{|l|l|} 
SYSTEM GROUP \\
\end{tabular}} & $\begin{array}{l}\text { HYORO } \\
\text { UNIT }\end{array}$ & FORMATION & $\begin{array}{c}\text { MAP } \\
\text { SYMBOL }\end{array}$ & THICKNESS \\
\hline \multirow{7}{*}{ 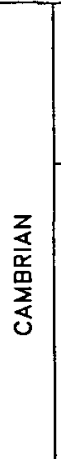 } & \multirow{2}{*}{ 竞 } & \multirow[t]{2}{*}{$\begin{array}{l}\text { 岸 } \\
\underline{z} \\
\end{array}$} & \multirow{2}{*}{ 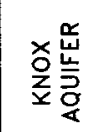 } & COPPER RIDGE DOLOMITE & ofk & $\begin{array}{c}\text { NOT } \\
\text { OETERMINED }\end{array}$ \\
\hline & & & & MAYNARDVILLE LIMESTONE & Emn & $418-450$ \\
\hline & & \multirow{5}{*}{ 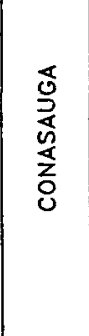 } & \multirow{6}{*}{ 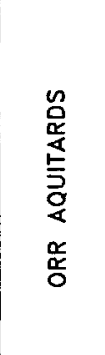 } & NOLICHUCKY SHALE & in & $422-550$ \\
\hline & 岌 & & & MARYVILLE LIMESTONE & $\epsilon m$ & $346-445$ \\
\hline & & & & ROGERSVILLE SHALE & Erg & $90-120$ \\
\hline & & & & RUTLEDGE LIMESTONE & fit & $90-120$ \\
\hline & & & & PUMPKIN VALLEY SHALE & $\epsilon_{\mathrm{pv}}$ & $260-320$ \\
\hline & 竞 & & & ROME FORMATION & tr & \begin{tabular}{|c} 
NOT \\
DETRRMINED
\end{tabular} \\
\hline
\end{tabular}

WIJ ORR AQUITARDS

KNOX AQUIFER

Figure 2-2. Topography and Bedrock Geology of the Y-12 Plant Area 
A working area corresponding to approximate Y-12 Plant grid easting coordinates from 50,000 to $65,000 \mathrm{ft}$ and northing coordinates from 28,500 to $31,500 \mathrm{ft}$ was selected, incorporating all of the plant within the East Fork Regime (Fig. 2-3). Point source data within the working area, in the form of monitoring well logs and soil boring logs, were gathered. Those data reflecting the presence of fill were placed in separate data bases for wells and soil borings, from which condensed data tables were generated. These data tables were imported into MapInfo geographic information systems (GIS) software and were entered as separate GIS layers to facilitate specific query. Maps showing cut and fill zones within the Y-12 Plant area, generated by K-25 Site engineering personnel using topographic data, were digitized using AutoCad and were entered as a GIS layer. Additional layers consisting of building layouts, roads, and utility line locations were obtained and entered into the GIS data base. The layers were combined to produce a working map of the Y-12 Plant area showing the distribution of the defined cut and fill zones and the point source data. Hand-contouring of the fill thickness values resulted in an interpreted fill thickness (isopach) map. Because of the limited distribution of the data points, the accuracy of contours was checked against pre- and post-plant construction topographic maps, aerial photographs, and the cut and fill maps. This process allowed any topographic or physiographic controls that would assist in the accuracy of the interpretation of the contouring to be seen. The final interpreted fill thickness isopach map was compared with maps of contaminant plumes and other sources of information in attempts to see any influences of the fill upon groundwater and contaminant migration in the shallow subsurface. Observations and interpretations were then made in regard to all the data.

\subsection{GATHERING OF POINT SOURCE DATA}

Initially, the Updated Subsurface Data Base For Bear Creek Valley, Chestnut Ridge, and Parts of Bethel Valley on the U.S. Department of Energy, Oak Ridge Reservation, Revision 2 (Jones et al. 1994) was consulted for the purpose of selecting monitoring well locations within the study area from which lithologic log data could be extracted. Only those wells having lithologic descriptions of definite or presumed fill material were considered. From these data, a working data base was compiled in tabular spreadsheet format using Microsoft Excel software (Appendix Tables A1 and A2). Similarly, soil boring logs from geotechnical reports on file at both the Y-12 Plant and the K-25 Site were reviewed. Condensed data taken from these logs were placed in separate spreadsheets (Appendix Tables A3 and A4) to allow individual queries to be made of the two main data types.

\subsection{POPULATION AND EXPLANATION OF DATA TABLE FIELDS}

The following point source data fields, taken from the well installation and soil boring logs, are populated in the Appendix tables: loci:ion identification (LOCATION_ID), northing (NORTHING), easting (EASTING), gro: ad elevation (GNDELEV), depth to the top of weathered rock (TOWR), depth to the top of fresh rock (TOFR), fill thickness (FILLTHK), bottom of fill layer (BOTLYR), description of the fill (DESLYR), thickness of the unconsolidated interval (UNCONSOL), functional area within the Y-12 Plant (FUNCTLAREA), the geologic unit(s) penetrated by the well (GEOFORMPEN), a relative data confidence ranking (FILLCONFID), the reference cited (REFERENCE), and pertinent comments (COMMENTS).

The names of most of the data table fields are self-explanatory; however, the point source data within the field LOCATION_ID are named using a convention to permit the unique identification of each data point and require additional explanation. In the case of 


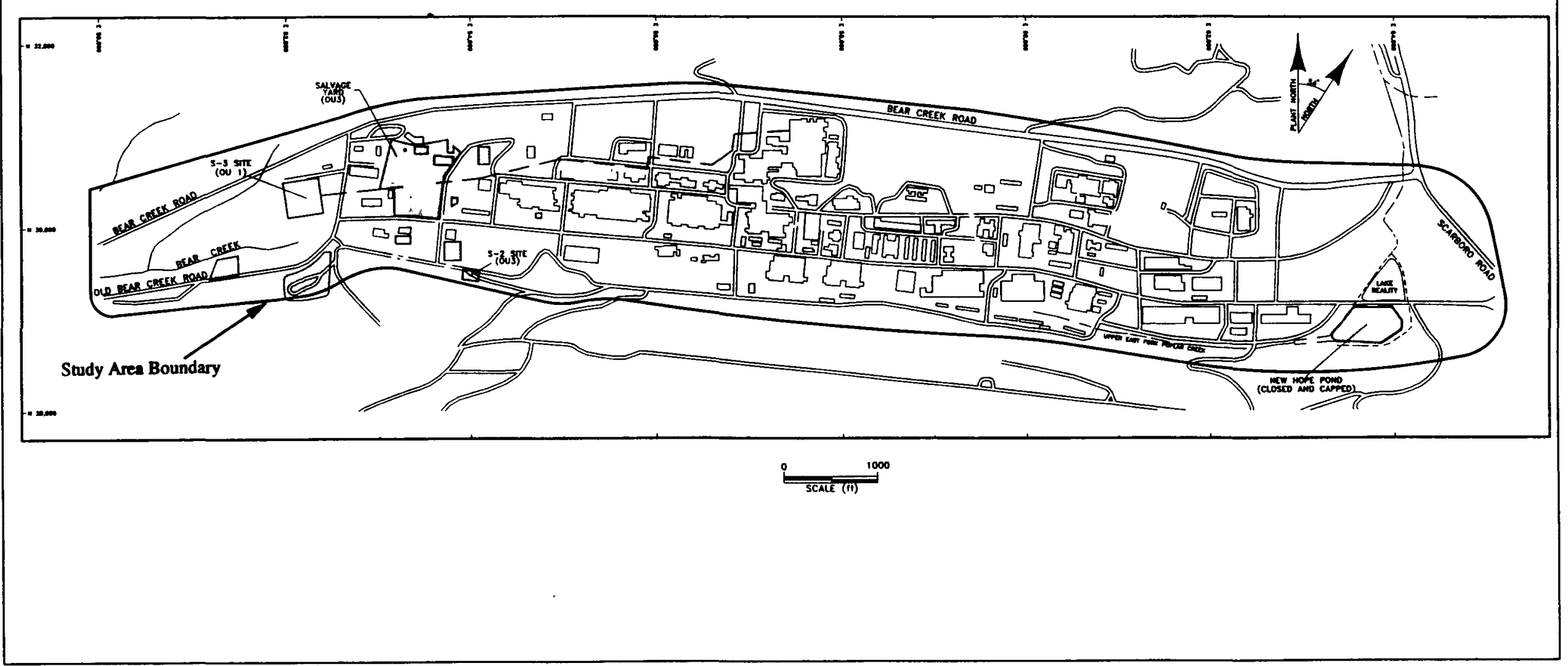

Figure 2-3. Y-12 Plant Anthropogenic Fill Study Area Boundary 
monitoring well data, prefixes of "GW" , “55" , “56" , or "59" have been assigned. Soil borings follow a different convention, with XXXX_AB-C_MMDDYY representing the general format where XXXX corresponds to the name of the drilling or boring contractor, $\mathrm{AB}-\mathrm{C}$ represents the boring name used by the contractor, and MMDDYY represents the month/day/year the boring was finished (if available). If the soil boring completion date was not available, the date indicated on the boring plan or elsewhere within the cited reference was used. This convention of naming soil borings was necessary as numerous borings were frequently given the same identifier. Table 2-1 lists the names of the boring contractors and their corresponding identification prefix.

Table 2-1. Contractor Identification Prefixes for Soil Boring Point Source Data

Identification Prefix
\begin{tabular}{|l|l|}
\hline GA & Geological Associates, Inc. \\
\hline GE & Geotek Engineering, Inc. \\
\hline GM & Geraghty and Miller, Inc. \\
\hline OE & Ogden Environmental and Energy Services Co., Inc. \\
\hline S\&ME & Soil and Material Engineers, Inc. \\
\hline ERCE & ERCE, Inc. \\
\hline EDGe & EDGe Group, Inc. \\
\hline ERC & ERC/EDGe, Inc. \\
\hline SAIC & Science Applications International Corp., Inc. \\
\hline
\end{tabular}

The field name NORTHING refers to the north coordinate for the borehole or well location, measured in feet, and referenced to the Y-12 Plant grid. The field name EASTING corresponds to the east coordinate, also in feet and in the Y-12 Plant grid system.

The field name GNDELEV is the ground elevation at the well or borehole, expressed in feet above mean sea level.

The field name TOWR represents the top of weathered bedrock and is given in feet below the ground surface at which in situ bedrock is first reached. The field name TOFR is the top of fresh bedrock, given in feet below ground surface; it represents the base of appreciable bedrock weathering. However, during one project in 1988, the depth to the top of fresh bedrock was arbitrarily defined by Geological Associates, Inc., as having a blowcount value ( $\mathrm{N}$-value) of greater than 100 (Appendix).

The field name UNCONSOL is the thickness of the unconsolidated interval, measured in feet. It represents the total thickness of the unconsolidated material present at the data point site and may include alluvium, colluvium, residuum, and anthropogenic fill material.

The field name FILLTHK is the thickness of the fill at the data point site in feet; it represents the total thickness of the anthropogenic fill material. In addition, the fill may include earth that has been cut and borrowed from other locations within the plant area. 
The field name FILLC .FID represents a relative confidence factor expressing the confidence the data bas. compiler had in the reported fill thickness (the certainty of it being fill and the certainty of the thickness) as determined from the examination of lithologic and soil boring logs. A value of " 1 " represents absolutely no confidence; a value of " 5 " represents high confidence. This factor was decided after comparing the presumed fill interval as reported in the logs with the defined fill areas identified on the cut and fill maps (Plate 1). If the coordinates of the boring in question did not match with any fill area on the cut and fill maps, the confidence was lower than if there had been a match. In addition, the fill description was considered; if it was accompanied by a descriptor such as "possible fill" or "probable fill" , the confidence was lower than had the descriptor "definite fill" or simply "fill" been indicated. This component of the confidence factor attempted to capture the confidence the boring logger had in the fill interval in hopes of providing a more accurate assessment of the fill at the data point sites.

In order to permit special queries of the types of fill material occurring at various depths below ground surface, additional fields delineating separate fill "layers" were incorporated within the data tables. A more accurate assessment of the fill material, and any hydraulic effects that separate fill layers may exert upon the groundwater in the water table interval may be realized from these fields. However, the fill material was at times described collectively for an entire section of the boring, preventing the identification of individual fill layers and their corresponding fill material. Even so, the recording of the additional information where available was convenient as the logs were being reviewed. The various depth ranges equate to individual fill layers, with each layer having a unique name and description. The field name BOTLYR1 (the bottom of fill layer 1) represents the distance from the ground surface to the bottom of fill layer 1 and is expressed in feet. The field name DESLYR1, indicating the description of fill layer 1, contains a brief description of material comprising the fill layer as reported in the lithologic and soil boring logs. The field name BOTLYR2 (the bottom of fill layer 2) is the distance from the bottom of fill layer 1 to the bottom of fill layer 2, expressed in feet. DESLYR2 is the description of fill layer 2. The remaining fill layers are named and described consecutively in the same manner.

The lowermost geologic formation penetrated by the borehole or well, when given in the logs, is provided in the field name GEOFORMPEN.

The field name FUNCTLAREA is the geographical or operational region within the Y-12 Plant in which the borehole or well is located.

The field name REFERENCE is the reference document from which the information and data were taken. The references consist primarily of geotechnical investigations and related documents for the soil borings and the Subsurface Data Base (Jones et al. 1994) for the well data.

Periodically, brief and general comments concerning the borehole or well data were found to be of interest and were placed within the field name COMMENTS.

At times, the terms "weathered" and "decomposed" shale are used in the fill layer descriptions. A distinction between the two terms is made, where "decomposed shale" refers to blow-count values (N-values) of less than 100 blows per foot. "Weathered shale", being the more competent of the two, refers to $\mathrm{N}$-values of greater than 100 blows per foot. 


\subsection{METHOD OF CONTOURING OF POINT SOURCE DATA}

The fill thickness isopach map was hand-contoured using the available monitoring well and soil boring point source data. The preliminary contouring interpretation was further refined by comparison of the data distribution with the defined cut and fill zone maps, topographic maps, and aerial photographs as discussed below. The completed fill thickness contours were digitized as a GIS layer in order to produce the final map.

\subsection{UTILIZATION OF DEFINED CUT AND FILL ZONE MAPS}

The defined cut and fill zone maps were generated by engineering personnel at the K-25 Site during 1986 . These maps were generated by plotting comparative differences between points on 1942 preconstruction topographic maps and 1979 postconstruction topographic maps. The process provided the areal boundaries that encompass the defined fill zones (Plate 1). Areas outside of the defined fill zones remained either at the same elevation or represent cut areas. The point source data were checked against the defined fill zones; data sites lying within the zones and having confidence factors of 4 and 5 strengthened the evidence for existence of the fill zones. Data sites lying outside of fill zones with the same confidence factors served to suggest that the areal extent of the fill zones could be increased to contain the data sites.

In some regions of the cut and fill zone maps, defined fill zones exist with no available data points. An example of this is the filled area centered approximately at $30,370 \mathrm{~N} ; 51,230 \mathrm{E}$, which encompasses Bear Creek Road (Plate 1). No point source data of either type were determined to exist here, and no consideration could be given to the actual extent of this fill zone. A 5-ft contour is drawn around the area as it is assumed that at least $5 \mathrm{ft}$ of fill would be present where previous road construction has undoubtedly taken place. Many other cut and fill zone areas have no associated data points; they had to be considered using a similar line of reasoning, usually with the assistance of topographic maps and aerial photographs.

\subsection{UTILIZATION OF TOPOGRAPHIC MAPS}

Topographic maps representing both preconstruction and present day topographies were used as tools to provide additional sources of control information during the contouring of the fill thickness data. The preconstruction maps were of 1942 vintage, and the present day topography was represented by 1979 maps.

\subsection{UTILIZATION OF AERIAL PHOTOGRAPHS}

Aerial photographs taken of the Y-12 Plant area prior to initial construction were helpful during the fill thickness contouring process in several areas. They provided the most assistance during contouring of the area of the Y-12 Plant referred to as Spoil Area I, located in the general region of 29,500 N; 52,000 E (Plate 1). Modern aerial photographs were used to show the current topography in the Spoil Area I, New Hope Pond, and Lake Reality areas. The photographs were also frequently used to confirm topographic features such as drainage channels and roads that were shown on the preconstruction topographic maps. 


\subsection{RESULTS, OBSERVATIONS, AND INTERPRETATIONS}

\subsection{MAJOR FILL ZONES WITHIN THE Y-12 PLANT AREA}

The fill zones, as defined by the cut and fill maps and shown on the fill thickness isopach map (Plate 1), occur primarily in areas of the Y-12 Plant where preconstruction surface drainage features were located. These areas represent valleys and topographic lows which were filled and altered to reroute the water flowing toward the UEFPC. The thickness of fill varies from less than $1 \mathrm{ft}$ to as much as $38 \mathrm{ft}$ (Appendix) and probably exceeds this in locations throughout the Y-12 Plant area. Many different types of material have been used as fill: crushed stone and gravel; clayey silt containing cinders; coal fines, bricks, wood, roofing shingles, and other various types of construction material (Appendix). The available fill data are nonuniform and distributed as closely spaced clusters of borings across the entire Y-12 Plant area.

Several major areas of thick fill were identified, many of which were associated with waste management sites. Thick deposits of fill are present in the Rust Spoil Area and the SY-200 Yard sites; with $18 \mathrm{ft}$ of fill observed at boring data point SAIC_SB-34_102093 and $17.5 \mathrm{ft}$ observed at SAIC_SB-08_111693 (Appendix, Plate 1). Fill thickness up to $38 \mathrm{ft}$ is present in the Spoil Area I Site at well data point GW-315 (Appendix, Plate 1); fill is present in the surrounding region as well, although in amounts less than $38 \mathrm{ft}$. Another major area where thick fill occurs is in the vicinity of the S2 Site, with boring data point OE_2-A_011093 just south of a filled channel showing $16.5 \mathrm{ft}$ of fill (Appendix, Plate 1). At the Waste Coolant Processing Area, fill ranges from a few feet to $29 \mathrm{ft}$ in thickness, primarily near the location of a filled stream channel (Plate 1). Along the length of the UEFPC channel, fill is generally less than $10 \mathrm{ft}$, according to the available data (Appendix, Plate 1). Thick fill exists in the Building 9212 vicinity. Well GW-784 penetrates $18.5 \mathrm{ft}$ of fill west of the area, boring data point S\&ME_WC-6_042589 shows $31 \mathrm{ft}$ of fill east of the area, and boring data point GA_103_020689 indicates fill of $25 \mathrm{ft}$ thickness in the southern portion of the area (Appendix, Plate 1). The Ravine Disposal Area also contains several fill deposits. The easternmost zone has $17 \mathrm{ft}$ of fill emplaced (boring data point ERCE_B-4_102491, Appendix, Plate 1); the zone located in the western portion of the Ravine Disposal Area has $18.8 \mathrm{ft}$ (well data point GW-768); and $19.5 \mathrm{ft}$ (boring data point ERCE_VC-4_072490) represents the maximum thickness of fill (Appendix, Plate 1).

\subsection{INTERPRETATION OF FILL ZONES}

\subsubsection{Western Plant Area}

Monitoring well GW-310 at the Rust Spoil Area, with a fill thickness of $14 \mathrm{ft}$ and a confidence factor of 5 (Appendix, Plate 1), indicates that the cut and fill zone near which it is located could be extended to the southeast by several feet. The well is located $20 \mathrm{ft}$ southeast of the zone boundary in a drainage ditch that is not shown on preconstruction topographic maps. The ditch is probably the result of a cut operation as the 1979 topography indicates considerable changes have been made. Accordingly, a 5-ft fill thickness contour is drawn south of this well to recognize it as a useful point. Likewise, the $6 \mathrm{ft}$ of fill ( 5 confidence factor) at well GW-100 would appear to allow the areal extent of the cut and fill zone to be increased toward the north to contain this point. However, no additional supporting data are present as extensive drilling has not occurred in the area. In addition, the topography of the surrounding area has changed relatively little since 1942. Therefore, a 5-ft contour was not drawn to encompass this point. Also, soil borings in the 
vicinity of boring OE_WETF-7_081992, with fill thicknesses ranging from 5 to $10.5 \mathrm{ft}$ and having a high confidence factor, suggest that the cut and fill boundary could be extended to contain these points. A 5-ft contour was drawn to surround the group of boring points, and a 10-ft contour was added to relate these points within the group.

Preconstruction aerial photographs of the Y-12 Plant area were used to help determine the placement of contours in the Spoil Area I region, located in the vicinity of coordinates of 29,500 N; 52,000 E (Plate 1). Here, monitoring wells GW-313, GW-314, GW-315, and GW-316 showed fill thickness ranging from 6 to $38 \mathrm{ft}$. Soil boring SAIC_P-1_100593 is located just east of well GW-315 and has $37.5 \mathrm{ft}$ of fill. There is no doubt that fill operations were performed here in the past, as descriptions of the fill include wood, brick, nails, particle board fragments, and clear plastic (Appendix). However, no zone of fill has previously been defined in this area. The preconstruction photographs allowed the general relief of the area to be studied, although with difficulty due to the relatively small scale of the photographs. Larger scale photos of the same area were available and served to assist in the verification of features determined using the small scale photos, but were of little added value. Gently rolling topography with poorly defined drainage features was observed in the photos; this was verified by examination of the preconstruction topographic maps. When then compared with the modern topography, it appeared that a cut operation had been performed prior to fill emplacement. A 5-ft contour was drawn to envelope the Spoil Area I locality based on the information gathered from the photos, topographic maps, and defined cut and fill zone maps. Similarly, 10 through $35-\mathrm{ft}$ contours were also placed where appropriate. However, more data are required to improve this interpretation and to provide a more accurate assessment of the fill activities that have occurred here.

\subsubsection{UEFPC and Tributary System}

The UEFPC channel was significantly modified during the construction of the Y-12 Plant. The channel was altered in a more linear fashion along the southeastern part of the Y-12 Plant area, and its headwaters were captured and diverted vertically downward by the addition of an underground storm sewer system (HSW 1994; Rothschild et al. 1984). The portion of the creek that was straightened is shown on the southeastern portion of Plate 1. The meandering of the original creek indicated that the region was originally of relatively low relief and gentle slope; this was shown to be true from analysis of the preconstruction aerial photographs and topographic maps. Soil borings GE_B-2_051486 and GE_B-3_051486 indicate the presence of $10 \mathrm{ft}$ and $5 \mathrm{ft}$ of fill, respectively, immediately north of a relatively straight portion of the original creek; thus, a 10-ft contour was drawn about these points. To the east of these points, monitoring wells $\mathrm{GW}-380$, GW-381, and GW-382 penetrate fill thickness ranging from 0.5 to $0.6 \mathrm{ft}$. A moderate confidence factor of 3 was assigned due to the material description and the existence outside a fill zone (Appendix). Due to lack of other data points in the area, these wells were considered in the drawing of a 5-ft contour along the filled creek channel north of their vicinity. To the southwest of boring GE_B-2_051486, soil borings, OE_B-1_081093 and OE_B-2_080693 show fill to be 16.5 and $17.7 \mathrm{ft}$, respectively (Appendix). Although the fill description of these data points contained wood and black sand, they were not considered in the contouring process as they lie well south of UEFPC. The borings penetrate a manmade bench in the vicinity of a sharp switchback turn created during construction of East Patrol Road (Jago, personal communication, 1995).

All of the north-south tributaries/stream channels of UEFPC were either filled or replaced with storm drains during the initial construction of the Y-12 Plant (Rothschild et al. 1984; 
HSW 1994). These filled stream channels are shown on Plate 1 , and their potential impact on the groundwater contamination is discussed in a following section of this report. In some places, data points are located such that a relatively accurate fill thickness could be determined, as is shown by monitoring wells GW-633, GW-108, and GW-109 (Appendix, Plate 1). The fill thicknesses indicated by these data points are, respectively, $8.5,4$, and $5 \mathrm{ft}$. A 5-ft contour is drawn to encircle the filled channel at this site and generally follow its trend until control is taken by other data points. Another filled stream channel with data supporting a reasonably accurate fill thickness occurs south of the junction of three filled channels at approximately $29,900 \mathrm{~N} ; 60,680 \mathrm{E}$ (Plate 1). Soil boring EDGe_B-3_080288 indicates the fill in the channel to be $5 \mathrm{ft}$ in thickness (Appendix). However, no additional data points are available to substantiate this observation; without their presence, control for contouring is lost, and other sources of data and information must be used. An additional filled channel trends northwest to southeast and is centered at approximately $30,300 \mathrm{~N} ; 62,500 \mathrm{E}$, in the Ravine Disposal Area (Plate 1). Here, monitoring well GW-768, with data showing fill to be $18.8 \mathrm{ft}$ near the channel, allows a 15-ft contour to be drawn to contain the point. Control is once again lost due to the absence of additional data points, and other sources must be relied upon for a more accurate extension of contouring in the region of this filled channel.

An example of the application of the topography comparisons is observed at the filled stream channel having its origin at approximately $30,450 \mathrm{~N} ; 58,700 \mathrm{E}$ (Plate 1). The site of the stream channel origin was found to have a present ground elevation of approximately $985 \mathrm{ft}$ and a preconstruction elevation of $975 \mathrm{ft}$. The difference between the two values results in an estimated $10 \mathrm{ft}$ of fill material having been placed in this location. The defined cut and fill zone boundary through which the stream channel passed indicated that the source of the channel was not within a fill zone (Plate 1). The comparison, therefore, suggested that the zone could be extended further to the north than was previously determined. This value served as a control point for contouring, with a 10 -ft contour being brought northward to encircle several soil boring data points with high confidence ranking. These soil borings included S\&ME_B-22_090287, S\&ME_23A_090287, S\&ME_24_090187, S\&ME_25A_090187, S\&ME_26_090187, and S\&ME_27A_083187. The first three points show respective fill thicknesses of 12, 12.5, and $12 \mathrm{ft}$. The latter three showed respective fill thicknesses of 15,5 , and $6 \mathrm{ft}$. All of these points were considered in the drawing of the 10-ft contour as they had high confidence factors. A soil boring data point located a short distance to the north of these, S\&ME_B-15_091587, was not used in the contouring process as it was shown not to lie within a zone of fill.

A filled stream channel with its origin at approximately $31,270 \mathrm{~N} ; 56,990 \mathrm{E}$ was shown on the topographic map to lie within an asymmetrical valley, with the eastern side of the channel having a more gentle slope than the western side. This observation was used to construct a 5-ft contour around the filled channel, with the contour encompassing a wider area away from the channel origin as it approached the west (Plate 1). Two monitoring well data points, GW-784 and GW-785, had respective fill values of 18.5 and $8.5 \mathrm{ft}$, with the greater of the two being closer to the portion of the channel with the greater relief.

The filled channel with its origin at approximately $30,850 \mathrm{~N} ; 62,800 \mathrm{E}$ received around $5 \mathrm{ft}$ of fill at its origin according to the difference in elevation between the preconstruction and postconstruction topography. The origin of this stream is shown to lie outside of a cut and fill zone, allowing not only the addition of a 5-ft contour to be drawn around the channel but the extension of the cut and fill zone boundary toward the north as well. Further to the south, two channels are seen to combine to form a northwest-southeast trending channel. About $10 \mathrm{ft}$ of fill are present at the junction, as the preconstruction elevation was 
near $930 \mathrm{ft}$, whereas the present elevation is close to $940 \mathrm{ft}$. Thus, the comparison resulted in the addition of a control point about which a 10-ft contour was drawn (Plate 1). A 5-ft contour was drawn around the northernmost portion of the channel directly to the west of these points, including the channel origin. Another filled stream channel, with an origin close to $30,650 \mathrm{~N} ; 61,200 \mathrm{E}$ within a cut and fill zone, has approximately $15 \mathrm{ft}$ of fill in place. The elevation of the origin, about $978 \mathrm{ft}$ on the preconstruction map, is given as about $993 \mathrm{ft}$ on the present map, resulting in a $15 \mathrm{ft}$ fill value.

\subsubsection{Eastern Plant Area}

In the region of New Hope Pond and Lake Reality (Plate 1), preconstruction photographs indicated that several minor stream drainages were once present, and that many meanders were located along the section of UEFPC passing through the area. Several roads existed prior to the initial Y-12 Plant construction. Less relief is now present due to episodes of construction, including installation of the plant rail line. Fill was emplaced, probably to build up the low lying areas and create a suitable grade for the railway. The fill at soil boring data point GE_B-1_033187, located within the present Lake Reality (Appendix, Plate 1), indicates a thickness of $11.4 \mathrm{ft}$ of mainly silty clay and organic material. The surrounding data points show a range in fill thickness between 3 and $11.4 \mathrm{ft}$ with similar material descriptions. In view of the high confidence factor, a 10-ft contour was placed through them. A 5-ft contour was drawn around the perimeter of Lake Reality but could not be brought around the entire fill zone due to the thickness of fill at the available data points being less than $5 \mathrm{ft}$. The described fill thickness within Lake Reality represents fill that existed prior to its construction in 1987-1988. This fill is no longer present as the lake was excavated to a depth of around $13 \mathrm{ft}$ (Jago, personal communication, 1995).

\subsection{POTENTIAL IMPACTS ON CONTAMINANT DISTRIBUTION}

Groundwater contaminant plume distributions (HSW 1994; Fig. 3-1 and 3-2) were compared with the defined areal extent of the fill zones to provide insight as to the influences of the fill upon the transport and migration of contaminants in the shallow subsurface (water table interval). Hydraulic influences due to the presence of fill material and buried (filled) drainage channels are observed at several places within the study area. A filled stream channel located between wells GW-105 and GW-505 (Fig. 3-1, Plate 1) is believed to influence the migration of nitrates in this portion of the Y-12 Plant (HSW 1994). The overall trend of the nitrate plume in the water table interval follows the general trend of a buried channel that exists at this point (Fig. 3-1, Plate 1). The channel, prior to being filled during the initial Y-12 Plant construction, served as a tributary of the UEFPC; its existence is well documented on preconstruction topographic maps and aerial photographs. Analytical evidence supporting the control of the fill zone upon nitrate migration between the two wells consists of an observed, rapid decrease in concentration levels from 921 milligrams per liter (mg/L) to $1.1 \mathrm{mg} / \mathrm{L}$ over the approximately $200 \mathrm{ft}$ distance separating the wells (HSW 1994). The channel probably serves as a hydraulic conduit and possesses a high degree of permeability due to the various fill types and the varying degrees of consolidation found within the fill zones (Rothschild et al. 1984; Appendix). The filled channel may allow nitrate and other contaminants to migrate along with meteoric waters from the vicinity of well GW-105 in a generally southeasterly direction toward well GW-633 and ultimately well GW-108. Samples of the latter two wells showed nitrate concentrations of 3,629 and $13,100 \mathrm{mg} / \mathrm{L}$, respectively (HSW 1994). 


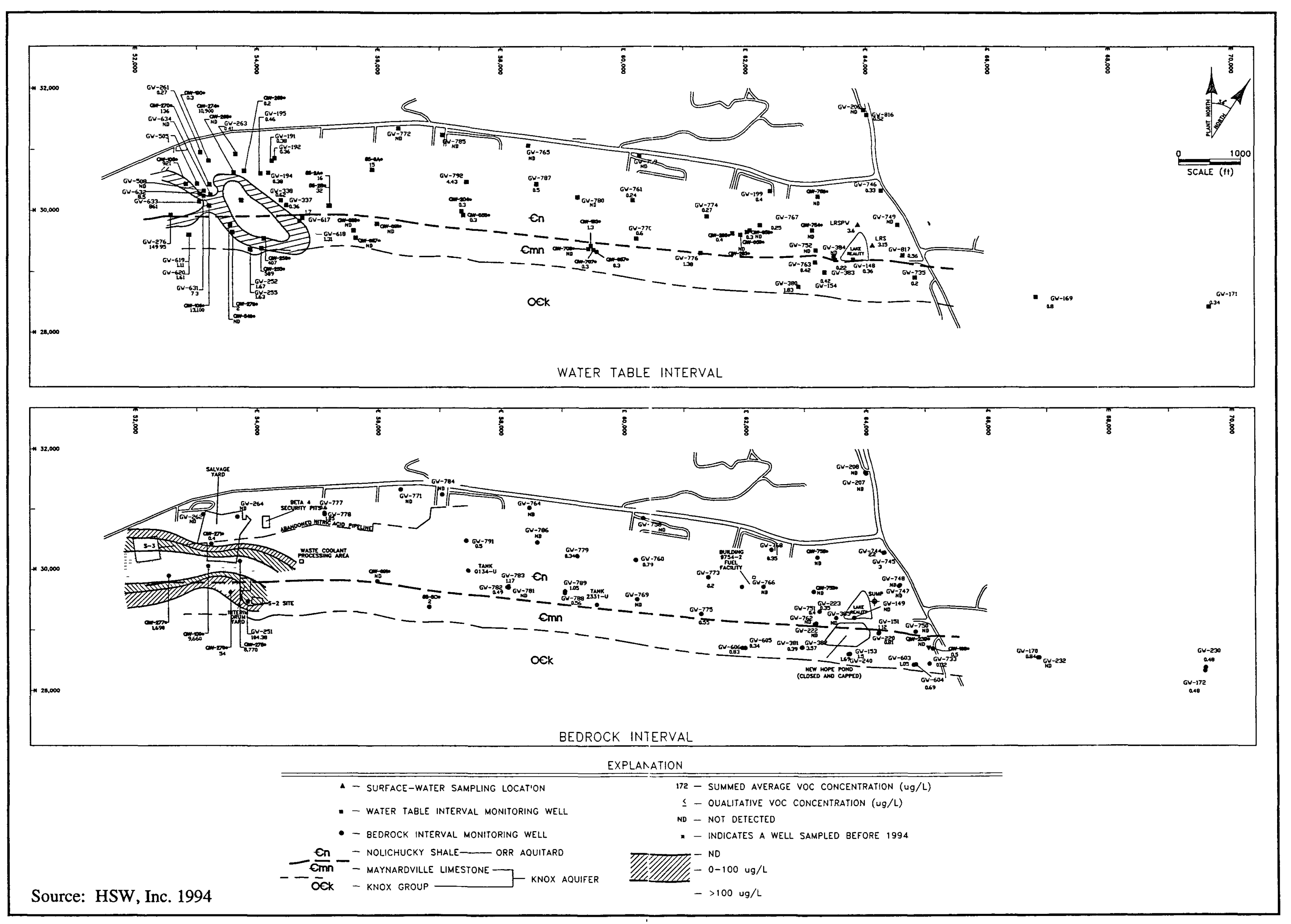

Figure 3-1. Nitrate in Groundwater in the Upper East Fork Poplar Creek Hydrogeologic Regime 


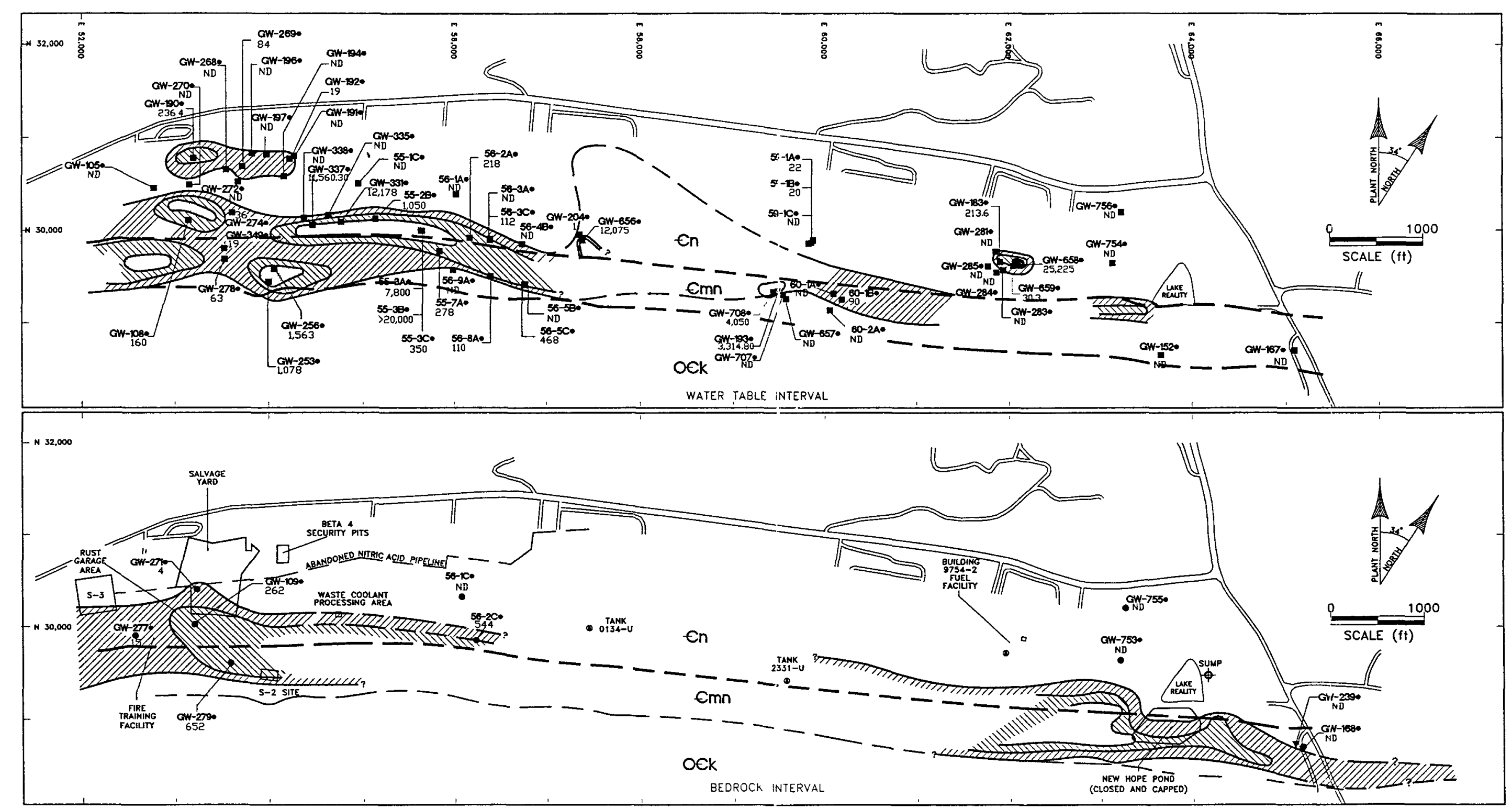

Source: HSW, Inc. 1994

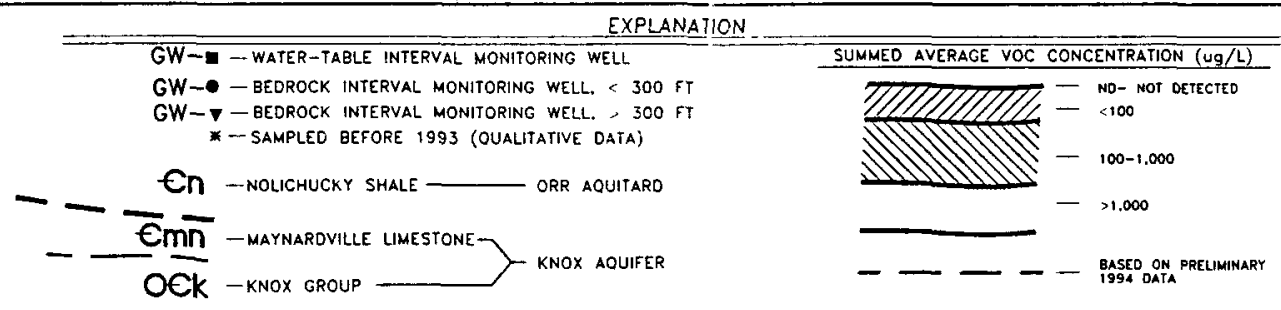

Figure 3-2. VOCs in Groundwater in the Upper East Fork Poplar Creek Hydrogeologic Regime 
Groundwater recharge both along Pine Ridge and downslope away from the ridge may serve to effectively dilute the contaminant concentrations in the northwest part of the plume, west of the stream channel, and allow the plume to be pushed toward the southeast via rapid flow through the fill material.

An apparent influence exists on VOC migration in the water table interval from a filled stream channel lying between wells GW-191 and GW-192, located east of the channel, and wells GW-194 and GW-197, both of which are located west of the channel and are presumably upgradient. Analysis of groundwater samples collected from wells GW-191, GW-194, and GW-197 did not indicate the presence of VOCs in this portion of the VOC contaminant plume; however, well GW-192 samples indicated a concentration of $19 \mathrm{ug} / \mathrm{L}$ (HSW 1994). This well is located approximately $8 \mathrm{ft}$ south of well GW-191 and presumably downgradient. This observation may be indicative of a preferential flow path within the fill material in the adjacent stream channel, permitting VOCs to migrate from an upgradient source.

The location of monitoring well GW-656 does not lie within a previously defined fill zone; however, examination of the lithologic log indicates that $6 \mathrm{ft}$ of fill are present at this site (Appendix). A summed chlorinated solvent concentration level of $12,075 \mathrm{ug} / \mathrm{L}$ was detected in calendar year 1993 in samples collected from the well (HSW 1994). A filled utility trench or other anthropogenic flow path may exist in the area, as groundwater samples from well GW-204, located upgradient and $70 \mathrm{ft}$ to the northwest of well GW-656, indicated only the presence of petroleum hydrocarbons and not chlorinated solvents (HSW 1994). The absence of chlorinated solvents in well GW-204 is indicative of an upgradient source of VOC contamination with a fill trench or channel serving to allow the transport of VOCs toward well GW-656 (HSW 1994). The existence of trench or channel is likely because the well penetrates $6 \mathrm{ft}$ of unconsolidated fill material that could readily serve as a highly permeable pathway for the transport of contaminants. An altemative explanation for the discrepancy in chlorinated solvents levels in the two wells is that an unidentified source exists between the wells (HSW 1994). 


\subsection{SUMMARY AND RECOMMENDATIONS}

The extent of the fill material within the Y-12 Plant area is widespread, with most of the fill being located in the vicinity of former surface drainage features. General comparison of contaminant plume distributions and cut and fill maps suggests that the location of fill zones does influence the direction of contaminant migration. The influence of fill on groundwater flow and contaminant transport will need to be considered in future revisions of the groundwater conceptual model in the Bear Creek Valley portion of the Oak Ridge Reservation.

The observations and interpretations offered in this report have been made considering currently available data. The findings presented must be considered preliminary due to the lack of point source data in many areas. As additional data become available, a more definite and accurate assessment of the findings will be possible. Suggestions and precautions that may help improve future studies of fill within the Y-12 Plant area are as follows:

1. Increase the quantity of point source data by determining the locations of any buried channels and trenches that may be present within the fill zones. Possible sources of this information are construction plans that may indicate subsurface utility trenches and similar buried features. These points may allow the areal extent of the fill zones to be broadened, and may assist in defining additional preferred migration pathways.

2. Recognize the uncertainties that exist when working in the Bear Creek Valley. The stratigraphy of the region is complex, and knowledge of the lithology may help in the interpretation of fill that may be present. As an example, the Maynardville Limestone is soluble and has weathered to produce a bedrock surface of varying relief. The depth to weathered bedrock may, therefore, dramatically change within a small area, with the thickness of the overlying unconsolidated deposits changing as well.

3. Reference the most recently prepared topographic maps for the greatest accuracy of contouring and delineation of topographic features.

4. Conduct a detailed review of contaminant data to refine relationships between source areas and potential migration pathways within fill zones. Signature contaminants may potentially be used to identify filled tributaries that function as preferred flow paths for specific source areas. 


\subsection{REFERENCES}

Geraghty and Miller, Inc. 1990. Comprehensive Groundwater Monitoring Plan for the Oak Ridge Y-12 Plant, Y/SUB/90-00206C/5, for Martin Marietta Energy Services, Inc., Oak Ridge Y-12 Plant.

Hatcher, R. D., Lemiszki, P. J., Dreier, R. B., Ketelle, R. H., Lee, R. R., Leitzke, D. A., McMaster, W. M., Foreman, J. L., and Lee, S. Y. 1992. Status Report on the Geology of the Oak Ridge Reservation, ORNL/TM-12074, Martin Marietta Energy Systems, Inc., Oak Ridge National Laboratory.

HSW 1994. Calendar Year 1993 Groundwater Quality Report for the Upper East Fork Poplar Creek Hydrogeologic Regime, Y-12 Plant, Oak Ridge, Tennessee: 1993 Groundwater Quality Data and Interpretations and Proposed Program Modifications, Y/SUB/94-EAQ10C/2/P2, HSW Environmental Consultants, Inc., for Martin Marietta Energy Systems, Inc., Oak Ridge Y-12 Plant.

IT 1986. Geohydrological Investigation of the Diesel Spill at the Y-12 Plant Service Station, Contract No. 408927.01, IT Corporation for Martin Marietta Energy Systems, Inc., Oak Ridge Y-12 Plant.

Jago, W. K. 1995. Lockheed Martin Energy Systems, Inc., personal communication to G. E. Sutton Jr. concerning fill descriptions of data points within the East Patrol Road portion of the Y-12 Plant, July 1995.

Jones, S. B., Thompson, B. K., and Field, S. M. 1994. Updated Subsurface Data Base for Bear Creek Valley, Chestnut Ridge, and Parts of Bethel Valley on the U.S. Department of Energy Oak Ridge Reservation, Y/TS-881/R2, Martin Marietta Energy Systems, Inc., Oak Ridge Y-12 Plant.

Rothschild, E. R., Turner, R. R., Stow, S. H., Bogle, M. A., Hyder, L. K., Sealand, O. M., and Wyrick, H. J. 1984. Investigation of Subsurface Mercury at the Oak Ridge Y-12 Plant, ORNLTM-9092, Martin Marietta Energy Systems, Inc., Oak Ridge National Laboratory.

Solomon, D. K., Moore, G. K., Toran, L. E., Dreier, R. B., and McMaster, W. M. 1992. Status Report: A hydrologic Framework for the Oak Ridge Reservation, ORNL/TM-12026, Martin Marietta Energy Systems, Inc., Oak Ridge National Laboratory 


\section{APPENDIX}

Tabulation of Monitoring Well and Soil Boring Point Source Data 


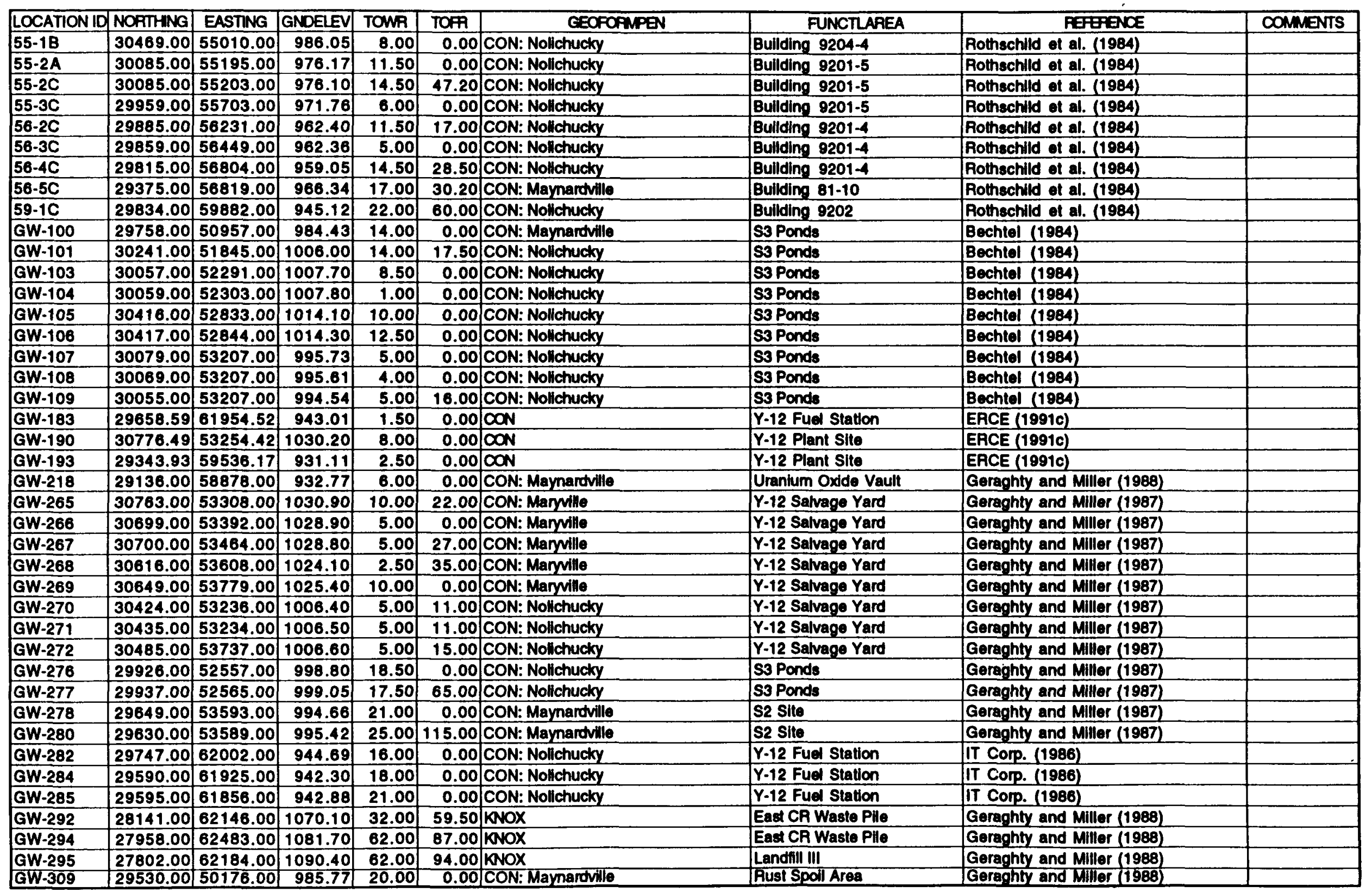




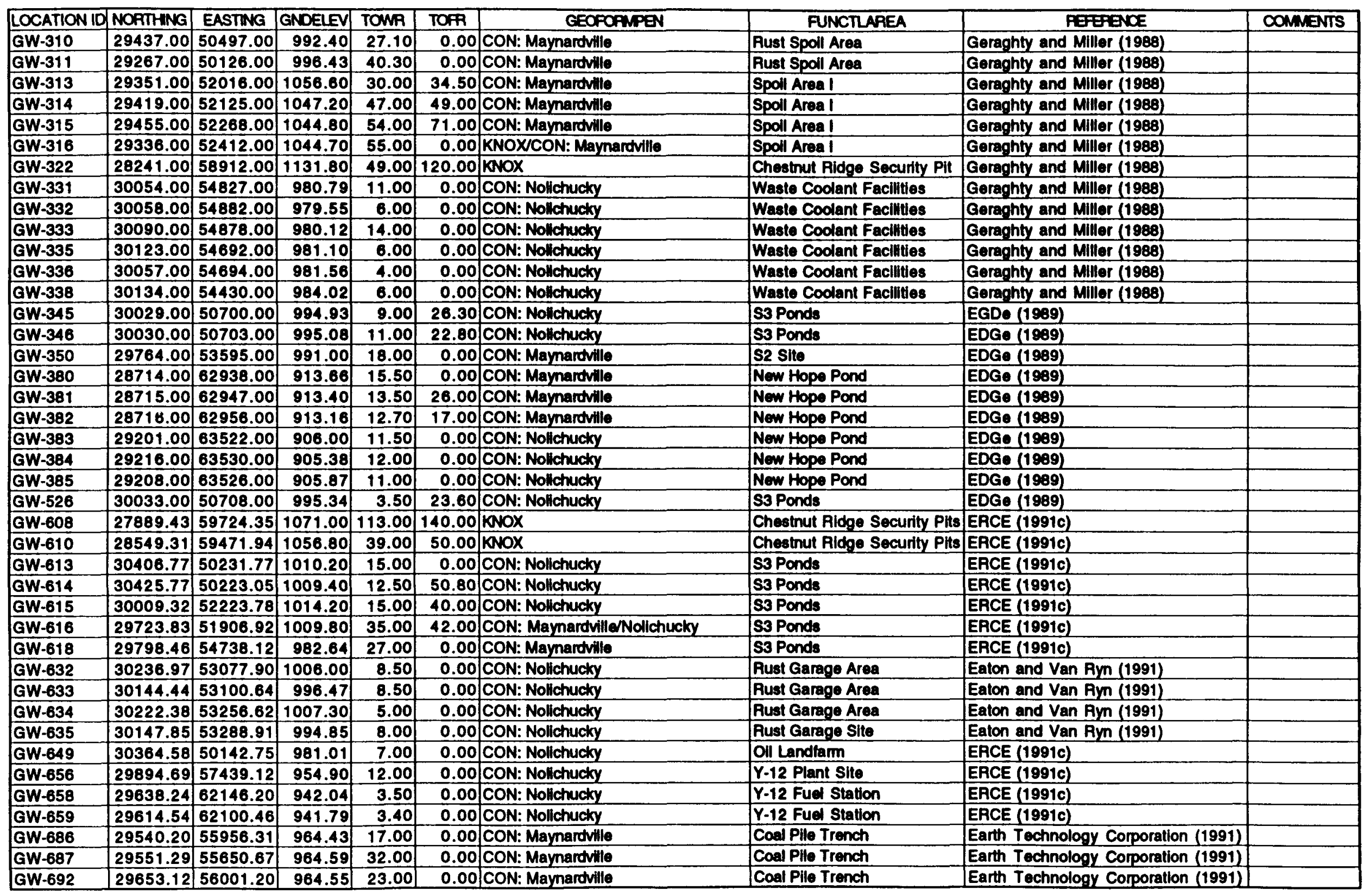




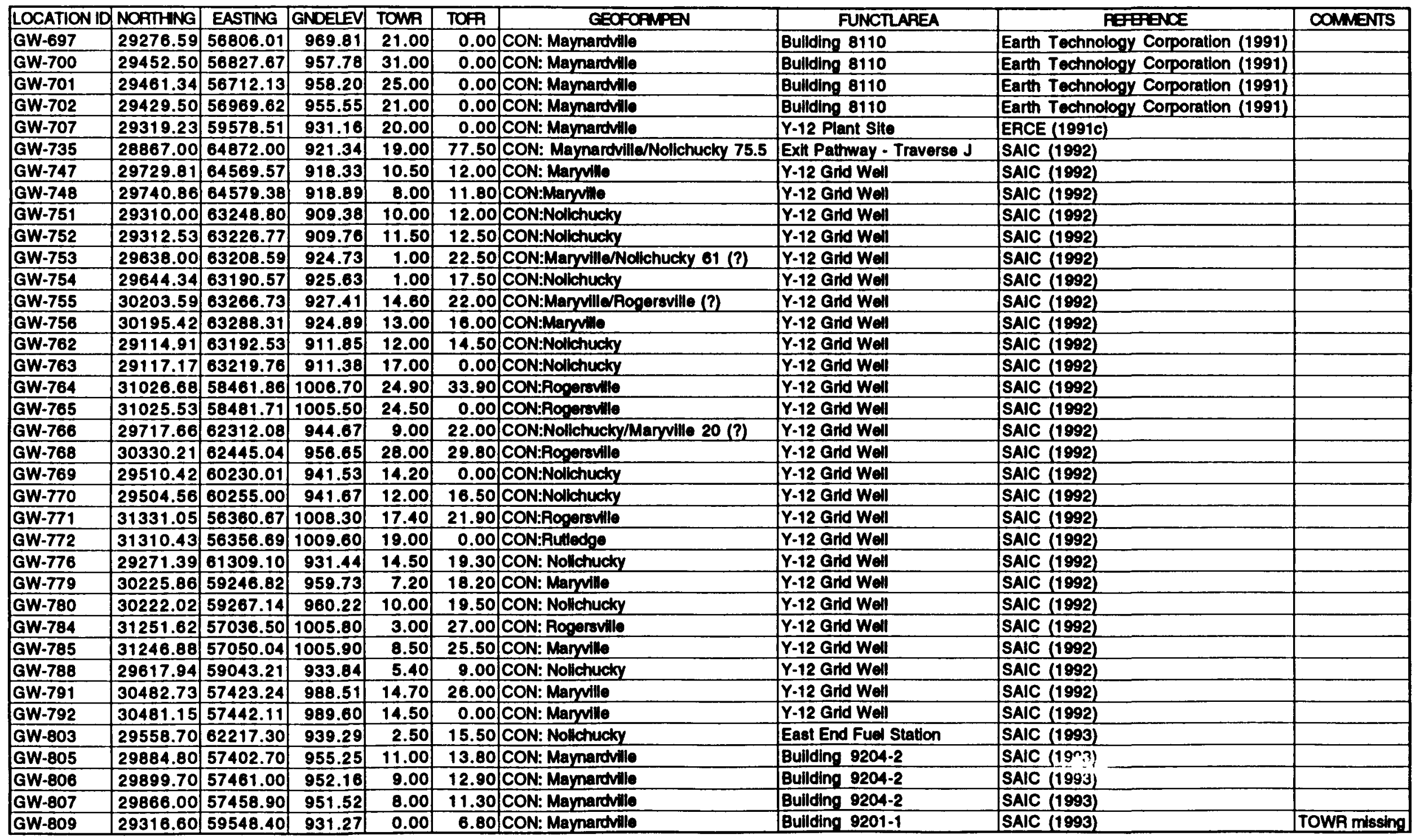

A-3 


\begin{tabular}{|c|c|c|c|c|c|c|c|c|c|}
\hline DOCATIONT & NOONSOI & FLLTHK & FRLCONFD & BOTLYAI & DESYYA1 & TEOIYPE & DESLYPQ & BOIYRO & DESTYAB \\
\hline $55-18$ & 8.00 & 1.50 & \begin{tabular}{|r|}
5 \\
\end{tabular} & 1.50 & Fill, nol described in log (posesibly roed prevel and coll) & & & & \\
\hline $55-2 A$ & 11.50 & 9.50 & 5 & 0.50 & Roed gravel, clay & & & & \\
\hline $55-2 \mathrm{C}$ & 14.50 & 12.00 & 5 & 12.00 & Unconsol. clay, gravel, esphah, compected clay & & & & \\
\hline $55-3 \mathrm{C}$ & 6.00 & 7.00 & 5 & 7.00 & Cloy, chabo/mmestone clast & & & & \\
\hline $56-2 \mathrm{C}$ & 11.50 & 6.00 & 5 & 6.00 & Dolomilik oravil, cosien eand & & & & \\
\hline $50.3 \mathrm{C}$ & 5.00 & 4.50 & 5 & 4.50 & Compact cley, dolomile roed gravel, chale chets & & & & \\
\hline $56-4 C$ & 14.50 & 5.50 & 5. & 5.50 & Compect cloy, dolomile roed graval, thalo clats & & & & \\
\hline $56-5 \mathrm{C}$ & 17.00 & 17.00 & 5 & 17.00 & Compact clay, grevel, asphat, wood, brick, coppoer whre & & & & \\
\hline $50.1 \mathrm{C}$ & 22.00 & 3.50 & 5) & 3.50 & Soll, hard day & & & & \\
\hline GW-100 & 14.00 & 6.00 & 3. & 0.00 & Concrelle, eand, sill & & & & \\
\hline aW-101 & 14.00 & 8.00 & 5) & 0.00 & Sand, elle, pobblos, ciay, led brick, tyroloam & & & & \\
\hline QW-103 & 8.50 & 0.50 & 5 & 0.50 & Cong & & & & \\
\hline GW-104 & 1.00 & 1.00 & 5. & 1.00 & Chyy, graval, eoft fill & & & & \\
\hline aW-105 & 10.00 & 2.50 & 5. & 2.50 & Sim, eand & & & & \\
\hline aW.106 & 12.50 & 3.00 & 5 & 3.00 & Cloy, and, oremel & & & & \\
\hline aW-107 & 8.00 & 5.00 & St & 5.00 & 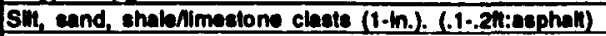 & & & & \\
\hline GW-100 & 4.00 & 4.00 & 3) & 0.50 & Roed bad pravel & 4.00 & Cloy, eand, oravel & & \\
\hline QW.100 & 5.00 & 5.00 & 8 & 0.50 & Raed bed raval & 5.00 & Simy clay, oravol, eand & & \\
\hline OW.103 & 1.50 & 1.50 & 5 & 0.50 & Asphall & 1.50 & Brovel & & \\
\hline GW-100 & 0.00 & 1.50 & st & 1.50 & Oromel & & & & \\
\hline aW.103 & 2.50 & 1.00 & 5) & 0.50 & Asphall & 1.00 & Graved & & \\
\hline GW-218 & 6.00 & 0.00 & 5 & 0.00 & Gravel,clyy & & & & \\
\hline OW-205 & 10.00 & 10.00 & s] & 10.00 & Limestone pravel, clay, weathered thate & & & & \\
\hline QW.206 & 5.00 & 5.00 & 5 & 5.00 & 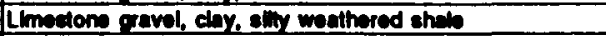 & & & & \\
\hline aW-207 & 5.00 & 5.00 & 5 & 5.00 & Limedione ravel, ell & & & & \\
\hline aW.208 & 2.50 & 2.50 & 5 & 2.50 & Limestone orevel, elli & & & & \\
\hline QW-200 & 10.00 & 10.00 & 5 & 10.00 & Limedtons prevel, dey, sin & & & & \\
\hline GW-270 & 5.00 & 5.00 & 5 & 3.00 & Limedione prevel, dey, elim & & & & \\
\hline aW-271 & 5.00 & 3.00 & 5] & 8.00 & Llmeatone pravel, all & & & & \\
\hline GW-272 & 5.00 & 5.00 & s] & 8.00 & Llmedone pavel, cley, sll & & & & \\
\hline QW.270 & 18.50 & 2.00 & s) & 2.00 & Limestone prevel, ellu, clay & & & & \\
\hline OW-277 & 17.50 & 5.00 & 5) & 5.00 & Limeatone pravel, ath, clay & & & & \\
\hline $0 . W .270$ & 21.00 & 4.00 & 5| & 4.00 & Llinedone gravel, an & & & & \\
\hline GW-200 & 25.00 & 2.50 & 5) & 2.30 & Limectone piavel, eth & & & & \\
\hline GW-202 & 16.00 & 3.00 & 4 & 3.00 & sin, eand, graval & & & & \\
\hline GW-204 & 18.00 & 6.50 & 4 & 6.50 & Sili, clay, grevel, limectono frapmente & & & & \\
\hline OW-285 & 21.00 & 6.50 & 4 & 0.50 & Soll backilli, elli, cloyoy gravel & & & & \\
\hline GW.202 & 32.00 & 4.00 & 5 & 4.00 & Fill (not desecrbed ln log) & & & & \\
\hline GW-204 & 62.00 & 5.00 & 5 & 3.00 & Clay, sill, rock trapments & & & & \\
\hline GW.205 & 62.00 & 5.00 & 5 & 5.00 & Clay, elli, sand, germel, chert claets & & & & \\
\hline 6W-309 & 20.00 & 4.00 & 5 & 4.00 & Cloy eand grevel & & & & \\
\hline GW-310 & 27.10 & 14.00 & 5 & 14.00 & Cloy, eand, grevel & & & & \\
\hline GW-311 & 40.30 & 4.00 & s. & 4.00 & Clory, eand gravol & & & & \\
\hline GW-313 & 30.00 & 14.00 & 5 & 14.00 & Gravel, eand & & & & \\
\hline GW-314 & 47.00 & 27.00 & 5 & 27.00 & Clay, eand, limeatone gravel, wood, shingles, motal & & & & \\
\hline GW-315 & 54.00 & 38.00 & 5 & 36.00 & Clay, orevel, thy-esh, wood, plastlc, brick & & & & \\
\hline GW-316 & 55.00 & 6.00 & s. & 6.00 & Gravel eand, day & & & & \\
\hline GW.322 & 49.00 & 2.00 & 5 & 2.00 & Gravel, sill, organic matter & & & & \\
\hline GW-331 & 11.00 & 4.00 & 5 & 4.00 & Cloy end, pravel & & & & \\
\hline GW-332 & 6.00 & 4.00 & S| & 4.00 & Cloy eand, gravel & & & & \\
\hline OW-333 & 14.00 & 7.00 & 5 & 7.00 & Cloy eand, oravel & & & & \\
\hline GW-335 & 6.00 & 4.00 & 5 & 4.00 & Cley eand, gravel & & & & \\
\hline GW.336 & 4.00 & 4.00 & 5 & 4.00 & Clay eand, gravel & & & & \\
\hline OW-330 & 6.00 & 2.00 & 5 & 2.00 & Clay, silh, sand & & & & \\
\hline
\end{tabular}


Table A2. Monitoring Well Point Source Data Fill Characteristics (Continued)

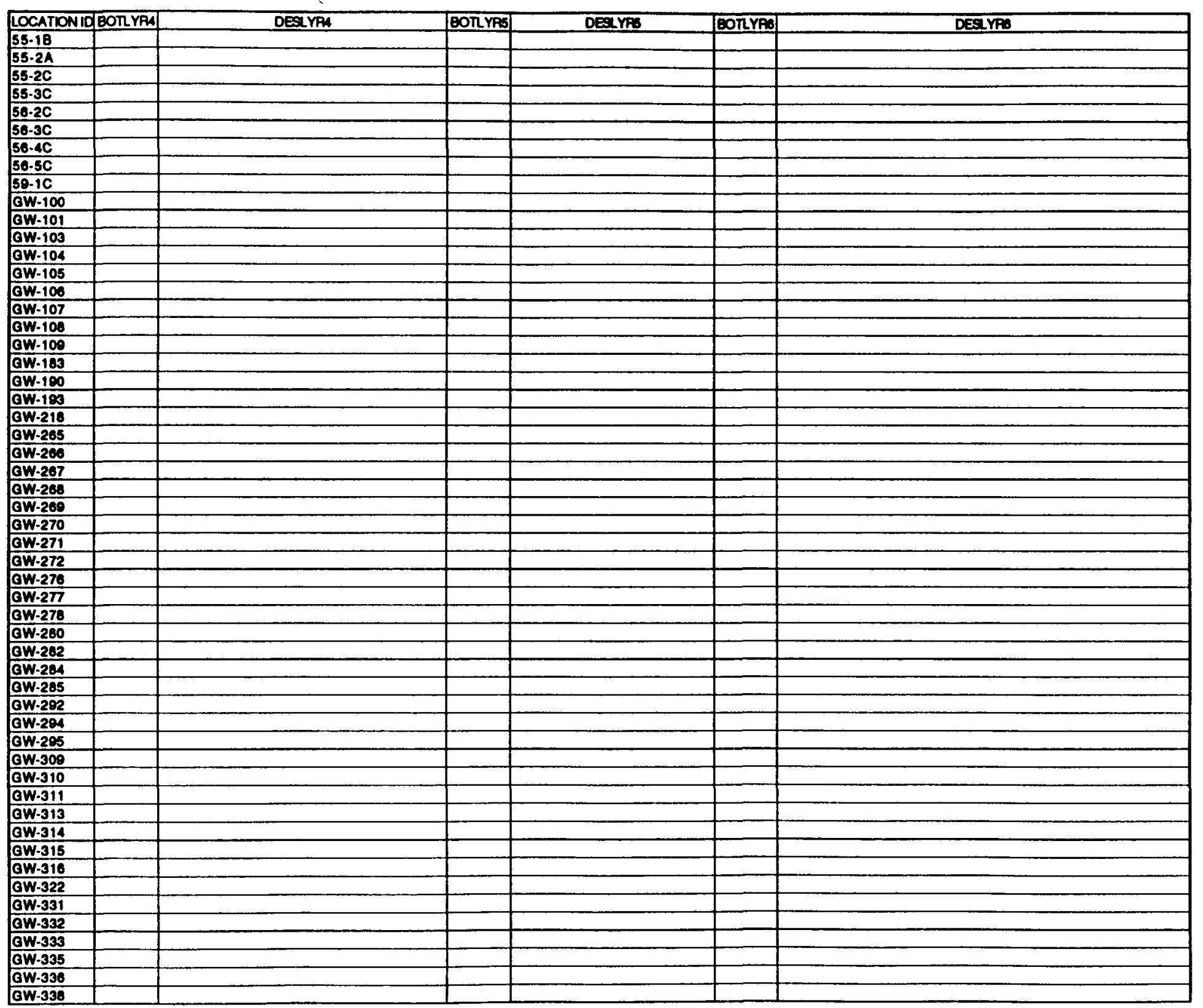




\begin{tabular}{|c|c|c|c|c|c|c|c|c|c|}
\hline LOCATIO & consal & FLLTKK & FLLONFD & BOIYAII & DESYYAI & BOŇYAR & DESYPR & BOn & DESYYPB \\
\hline GW-345 & 9.00 & 0.50 & 4 & 0.50 & Gravel & & & & \\
\hline GW-346 & 91.00 & 1.00 & 4 & 1.00 & Gravel & & & & \\
\hline GW-350 & 18.00 & 0.50 & 5 & 0.50 & Gravel & & & & \\
\hline QW-380 & 15.50 & 0.00 & 3 & 0.00 & arnvel pad and topsoll & & & & \\
\hline GW-361 & 13.50 & 0.50 & 3 & 0.50 & Gravel and lopsoll & & & & \\
\hline QW.302 & 12.70 & 0.50 & 3 & 0.50 & Gravel and topeolf & & & & \\
\hline $0 W-303$ & 11.50 & 5.40 & 5 & 0.00 & Gravel pad & 1.50 & Clay, grase, rooks & 5.40 & Clay, gravel, red brick fragmements \\
\hline QW-384 & 12.00 & 0.00 & 5 & 0.20 & Graval pad & & & & \\
\hline GW-305 & 11.00 & 2.00 & 5 & 2.00 & Gravel ped and clay soll & & & & \\
\hline QW-526 & 3.50 & 0.50 & 4 & 0.50 & Graved & & & & \\
\hline OW.600 & 113.00 & 1.00 & 4 & 1.00 & Gravel pad & & & & \\
\hline GW.610 & 30.00 & 2.00 & 4 & 2.00 & Gravel, roud bed clay & & & & \\
\hline QW-613 & 15.00 & 0.60 & 4 & 0.00 & Grevel pad & & & & \\
\hline GW-614 & 12.50 & 0.50 & 4 & 0.50 & Grovel pad & & & & \\
\hline OW-615 & 15.00 & 13.50 & 5 & 4.00 & Soll, bricks, bouldere, metal, olc. & 13.50 & Cloy, ill materlal & & \\
\hline QW-616 & 35.00 & 10.00 & 5 & 3.00 & Graved, cloy, dobris, llimedione boulder & 10.00 & Cloy, (t) malental & & \\
\hline GW.618 & 27.00 & 1.00 & s] & 1.00 & Gravel & & & & \\
\hline GW.632 & 0.50 & 3.00 & 5 & 3.00 & Limeatone pravel & & & & \\
\hline GW.633 & 0.50 & 8.50 & 5 & 0.50 & Clayey gravel (1-70mm), wood frapmente & & & & \\
\hline GW.634 & 5.00 & 5.00 & 5 & 5.00 & Claper pravel & & & & \\
\hline GW-635 & 0.00 & 5.00 & 5 & 5.00 & Clayer pravel & 0.00 & Allumal valloy fill (cloyey elli, lock dests) & & \\
\hline GW-649 & 7.00 & 0.50 & 4 & 0.50 & Cnuhed rock ped & & & & \\
\hline GW.050 & 12.00 & 0.00 & 5 & 1.30 & Concrete & 3.50 & Cruathed wons, all & 5.00 & Flum day \\
\hline GW. 650 & 3.50 & 0.00 & 5 & 0.30 & Aephallic concrete & 0.00 & Grovel & & \\
\hline OW.650 & 3.40 & 1.40 & 5 & 0.40 & Alphallic concrete & 1.40 & ananel & & \\
\hline aW-606 & 17.00 & 15.00 & 5 & 5.00 & Grove & 10.00 & $\cos y$ & 15.00 & Clay, graval \\
\hline QW.697 & 32.00 & 3.00 & 5 & 3.00 & Conl, gravel & & & & \\
\hline OW.602 & 23.00 & 0.00 & 5 & 0.50 & Aephat: N.B.: SEE NOTE ON BOREHOLE WNLD: & 0.00 & NOTE Concrelo plpe Q of BGS, ath from GW-692 & & \\
\hline QW.607 & 21.00 & 0.50 & 5 & 0.50 & Concrato & & & & \\
\hline OW.700 & 31.00 & 11.50 & 5 & 1.00 & Oraml, eand & 4.00 & Giaved, clay & 10.50 & Sility to pebblllterous cloy \\
\hline aW.701 & 25.00 & 12.00 & 5 & 12.00 & 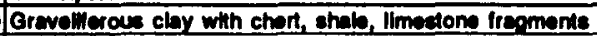 & & & & \\
\hline GW-702 & 21.00 & 7.00 & 5 & 2.00 & Gravel, roed bed cloy & 7.00 & Pobbellierous clay, culvert at m.BQS & & \\
\hline aW.707 & 20.00 & 20.00 & $\mathbf{5}$ & 1.00 & Asphait & 4.00 & Creosoled timber & 20.00 & Poesdible concriote \\
\hline QW-735 & 10.00 & 6.00 & 3 & 0.00 & Subeollilil & & & & \\
\hline OW.747 & 10.50 & 4.00 & 5 & 0.80 & Soll, aravel, coal & 4.00 & Shab, caal fragments & & \\
\hline 6W.740 & 8.00 & 0.50 & 5 & 0.50 & Soll, perved, can & & & & \\
\hline GW-751 & 10.00 & 3.00 & 5 & 3.00 & Loamy coll, canise brlck frapmome, gravel & & & & \\
\hline GW.752 & 11.50 & 1.50 & 5 & 1.50 & Shale cleats, coares gravel, larpo brick Irepments & & & & \\
\hline GW-753 & 1.00 & 1.00 & 5 & 1.00 & Clevey soll, weathored chale clacts, gravel roed fill & & & & \\
\hline GW.754 & 1.00 & 1.00 & 5 & 1.00 & Soll, gravel tragmente & & & & \\
\hline aW-755 & 14.60 & 6.50 & s & 3.50 & Gravel, chab clacts & 0.50 & Wood, shale fragments & & \\
\hline QW.756 & 13.00 & 3.50 & 5 & 0.50 & Compactod dilt road gravol & 3.50 & Gravel, thaib frapments & & \\
\hline OW.762 & 12.00 & 7.50 & 5 & 1.00 & Asphall & 2.00 & 1-105-h. Immostone appregale, soll fill & 3.50 & Silly clay Iill \\
\hline GW.703 & 17.00 & 5.00 & 5 & 0.50 & Aaphalf & 2.00 & Limestone gravel & 4.00 & Gievel, coal lines, sand \\
\hline GW-704 & 24.00 & 10.20 & 5 & 10.80 & Sol, fill material, graval & & & & \\
\hline GW.705 & 24.50 & 16.00 & 5 & 16.00 & Clayoy coll, fill malorlal, gravel & & & & \\
\hline GW-766 & 0.00 & 6.50 & 5 & 0.50 & Soll & 2.00 & Chyey soll the, grevel, red clay plposilo trapments & 0.50 & Clayey soll, till matorial \\
\hline GW.768 & 28.00 & 18.00 & 5 & 0.50 & Grovel roed bases & 18.80 & Notural residum & & \\
\hline GW-780 & 14.20 & 0.00 & 5 & 2.00 & Ralload bellase, Ilmestone gravel (2-10-3in.) & 8.00 & Clay lith wh shato & & \\
\hline GW. 770 & 12.00 & 12.00 & 5 & 4.00 & Rallirond bece and sub-base, limeetione gravel & 12.00 & Compacted aloy IIII & & \\
\hline aW-771 & 17.40 & 7.50 & 5 & 5.00 & Loemy soll, fill material, gravel & 7.50 & Clayoy coll, fill malertal & & \\
\hline GW. 72 & 10.00 & 10.00 & 5 & 1.50 & Gravel fill mixed with topsoill & 10.00 & Clay fill with residual silny shate & & \\
\hline GW. 770 & 14.50 & 5.70 & 3 & 0.60 & Asphalt & 1.20 & Limeatone aporegate (1-10-3in.), soll in fillinges & & \\
\hline GW.779 & 7.20 & 2.50 & 5 & 2.20 & Hard coll, gravel lragments & 2.50 & Conres gravol bed & & \\
\hline
\end{tabular}


Table A2. Monitoring Well Point Source Data Fill Characteristics (Continued)

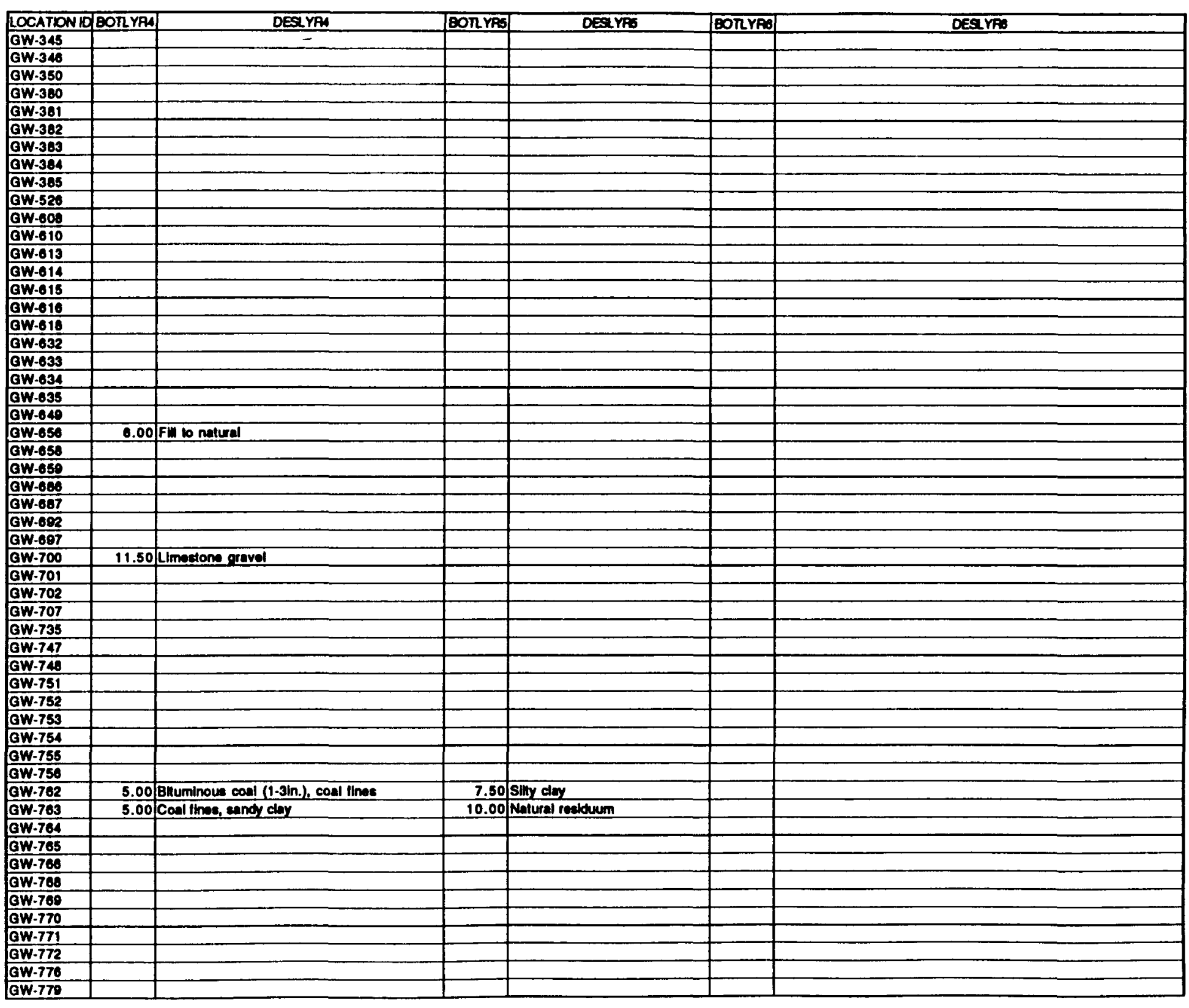


Table A2. Monitoring Well Point Source Data Fill Characteristics (Continued)

\begin{tabular}{|c|c|c|c|c|c|c|c|c|c|}
\hline LOCATION I & Inconsal & FLLTKK & FHLONFD & BOTLYAI & DESYYA1 & BOTYYA & DESYYR & BOTLYAT & DESYYPS \\
\hline GW.780 & 10.00 & 7.20 & 5 & 1.50 & Soll, gravel $(1-10-30 \mathrm{~cm})$ & 3.00 & Soll, gravel (chaib, limectono) & 7.20 & Fill of chale, limectione clacts \\
\hline GW.784 & 3.00 & 18.50 & 5 & 0.00 & Asphall & 3.00 & Clayey itu, gravel & 5.00 & Woathered rock in \\
\hline GW-765 & 8.50 & 8.50 & 5 & 0.00 & Asphall & 1.10 & Sandetelity coll, gravel & 4.20 & Graved (chalofilmestono), loam \\
\hline GW.786 & 5.40 & 2.00 & 5 & 2.00 & Coane ravel (2h).), soll fill & & & & \\
\hline GW.781 & 14.70 & 14.70 & 5 & 1.50 & Soll, organic colritus & 2.50 & Clayey eoll & 10.00 & Clay fill, rock, bouldere, oravil, thaile \\
\hline GW.792 & 14.50 & 4.00 & 5 & 1.00 & Soll & 2.00 & Cloyey fili, gravel, red clay brlckalle & 4.60 & Gravelly ill material \\
\hline GW.803 & 2.50 & 2.50 & s. & 2.50 & Fill clay wharpe anqular limestone lierments & & & & \\
\hline GW-805 & 11.00 & 2.50 & 5 & 0.50 & Asphalt & 2.50 & Clay w/anoular limestone, brick lragments & & \\
\hline GW.800 & 0.00 & 3.00 & 5 & 0.50 & Asphall & 3.00 & Cructier nun Iimestone gravel & & \\
\hline GW.807 & 0.00 & 4.00 & St & 4.00 & Fil clay wharpe anqular timestone fremente & & & & \\
\hline GW-800 & 0.80 & 6.20 & 5 & 0.5 & Asphall & 1.0 & Clay wilmectone irsomente, asphen frasm & 8.2 & Clay walmectone liseomente \\
\hline
\end{tabular}


Table A2. Monitoring Well Point Source Data Fill Characteristics (Continued)

\begin{tabular}{|c|c|c|c|c|c|c|}
\hline \multicolumn{2}{|c|}{ LOCATIONIDBOOYYRA } & \multirow[t]{2}{*}{ DESYYA } & \multirow[t]{2}{*}{ BOTLYA5 } & \multirow[t]{2}{*}{ DESTYF } & \multirow[t]{2}{*}{ BOITYA6 } & \multirow[t]{2}{*}{ DESYYAB } \\
\hline GW.780 & & & & & & \\
\hline GW-704 & 11.10 & Clayey IIII, coarse graval (2ln.), shale claste & 12.40 & Clayoy soll III, wasthered shaib & 10.50 & Wood (roots of branches), construction material (roolling paper) \\
\hline GW.785 & 0.50 & Crumbly clay, large fill fragments ( $(1 \ln )$. & & & & \\
\hline \multicolumn{7}{|l|}{ GW-780 } \\
\hline GW.791 & 14.70 & Clayey fll, rock, gravel, red clay Ille/brick & & & & \\
\hline \multicolumn{7}{|l|}{ GW.792 } \\
\hline \multicolumn{7}{|l|}{ OW.803 } \\
\hline \multicolumn{7}{|l|}{ GW-805 } \\
\hline \multicolumn{7}{|l|}{ OW-806 } \\
\hline GW-807 & & & F & & & \\
\hline GW.809 & & & & & & \\
\hline
\end{tabular}




\begin{tabular}{|c|c|c|c|c|c|c|c|c|c|}
\hline LOCATION ID & NOPTHING & \begin{tabular}{|l|} 
EASTING \\
\end{tabular} & GNDELEV & \begin{tabular}{|l|} 
TOWA \\
\end{tabular} & TOFA & GEOFOFMPEN & FUNCTLAREA & PFEANCE & DOMMENIS \\
\hline SAIC_SB-03_092193 & 29402.10 & 49991.90 & 992.70 & 36.90 & 0.00 & & RUST SPOLL AREA & SAIC (1994) & BCV OU 2 RI Appendix A \\
\hline SAIC_SB-04_092293 & 29417.60 & 50218.90 & 990.30 & 10.90 & 0.00 & & RUST SPOLL AREA & SAIC (1994) & BCV OU 2 AI Appendix A \\
\hline SAIC_SB-0B_111693 & 29681.50 & 51452.30 & 1004.10 & 18.00 & 0.00 & & RLUST SPOIL AREA & SAIC (1994) & BCV OU 2 RI Appendix A \\
\hline SAIC_SB-14_112993 & 29665.90 & 51476.50 & 1004.40 & 21.10 & 0.00 & & RUST SPPOL AAEA & SAIC (1994) & BCV OU 2 RI Appendlix A \\
\hline SAIC_SB-1B_111893 & 29652.00 & 51501.90 & 1004.10 & 12.00 & 0.00 & & ALST SPOIL_AAEA & SAIC (1994) & BCV OU 2 RI Appendix A \\
\hline SAIC_SB-21_101893 & 29557.60 & 51107.50 & 998.90 & 12.30 & 0.00 & & RUST SPOIL AREA & SAIC (1994) & BCV OU 2 RI Appendix A \\
\hline SAIC_SB-22_101193 & 29566.90 & 51130.10 & 998.70 & 10.60 & 0.00 & & RUST SPOIL AREA & SAIC (1994) & BCV OU 2 AI Appendix A \\
\hline SAIC_SB.44_101593 & 29505.30 & 51125.80 & 998.90 & 14.00 & 0.00 & & RUST SPOK AREA & SAIC (1994) & BCV OU 2 AI Appendix A \\
\hline SAIC_SB-45_101493 & 29500.50 & 51098.10 & 999.10 & 10.20 & 0.00 & & RUST SPOIL AREA & SAIC (1994) & BCV OU 2 AI Appendix A \\
\hline SAIC_SB-47_120293 & 29562.40 & 51497.70 & 1004.80 & 11.00 & 0.00 & & RUST SPOL_AREA & SAIC (1994) & BCV OU 2 RI Appendix A \\
\hline SAIC_P-1_100593 & 29443.20 & 52324.60 & 1044.60 & 63.80 & 0.00 & & RUST SPOL AAEA & SAIC (1994) & BCV OU 2 RI Appendix A \\
\hline ERCE_VC-1_072490 & $30287.00 \mid$ & 62871.00 & 942.10 & 12.00 & 0.00 & CON: shale & NEWHOPE CEMETEAY & ERCE (1990a) & \\
\hline ERCE_VC-2_072490 & 30282.00 & 62904.00 & 941.70 & 20.00 & 0.00 & CON: shale & NEW HOPE CEMETEPY & ERCE (1990a) & \\
\hline ERCE_VC-3_072490 & 30237.00 & 62861.00 & 940.50 & 17.50 & 0.00 & CON: shab & NEW HOPE CEMETERY & ERCE (1990a) & \\
\hline ERCE_VC-10_072490 & 30151.00 & 62890.00 & 935.70 & 15.00 & 0.00 & CON: shale & NEWHOPE CEMETERY & ERCE (1990a) & \\
\hline ERCE_VC-11_072490 & 30142.00 & 62934.00 & 935.10 & 19.50 & 0.00 & CON: shab & NEWHOPE CEMETERY & ERCE (1990a) & \\
\hline ERCE_VC-12_072490 & 30128.00 & 62995.00 & 932.70 & 20.00 & 0.00 & CON: shale & NEWHOPE CEMETERY & EACE (1990a) & \\
\hline OE_EE-2_120992 & 30294.00 & 63540.00 & 920.50 & 15.00 & 0.00 & OON & EAST END SANTARY SEWER & OGDEN (1992d) & \\
\hline OE_EE-3_120892 & 30230.00 & 63587.00 & 911.20 & 15.00 & 0.00 & OON & EAST END SANTARY SEWER & OGDEN (1992d) & \\
\hline OE_EE-7_120992 & 29913.00 & $63816.00 \mid$ & 907.00 & 14.00 & 0.00 & OON & EAST END SANTARY SEWER & OGDEN (1992d) & \\
\hline OE_EE-8_120992 & 29851.00 & \begin{tabular}{|l|}
63858.00 \\
\end{tabular} & 903.10 & 9.50 & 0.00 & DON & EAST END SANTARY SEWER & OOGDEN (1992d) & \\
\hline OE_EE-9_120992 & 29768.00 & \begin{tabular}{|l|}
63913.00 \\
\end{tabular} & 899.90 & 9.50 & 0.00 & OON & EAST END SANTAAY SEWER & OGDEN (1992d) & \\
\hline OE PS-5 052992 & $30563.00 \mid$ & 61616.00 & 969.90 & 13.00 & 0.00 & & EZA SWITCHYARD & OGDEN (1992b) & \\
\hline OE_PS-12_052992 & 30540.00 & 61245.00 & 994.80 & 11.50 & 0.00 & & EZZASWITCHYARD & OGDEN (1992b) & \\
\hline OE PS-13 052992 & \begin{tabular}{|l|}
30529.00 \\
\end{tabular} & $61316.00 \mid$ & 994.80 & 8.50 & 0.00 & & EIZA SWITCHYARD & OGDEN (1992b) & \\
\hline OE_PS-14_052892 & 30518.00 & 61387.00 & 994.40 & 20.50 & 0.00 & & EZZA SWTTCHYARD & OGDEN (1992b) & \\
\hline OE_PS.15 052892 & $|30511.00|$ & 61433.00 & 994.30 & 25.50 & 0.00 & & ELZA SWITCHYARD & OGDEN (1992b) & \\
\hline OE_PS.16_052992 & 30493.00 & 61544.00 & 992.20 & 26.00 & 0.00 & & EIZA SWITCHYYARD & OGDEN (1992b) & \\
\hline ERCE_PSO-1_092290 & 30359.50 & $59190.00 \mid$ & 973.00 & 8.00 & 0.00 & & Y-12 PLANT SUPAT./BLDG. 9115 & EHCE (1990d) & \\
\hline
\end{tabular}

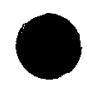


Table A3. Soil Borings Selected for Point Source Data (Continued)

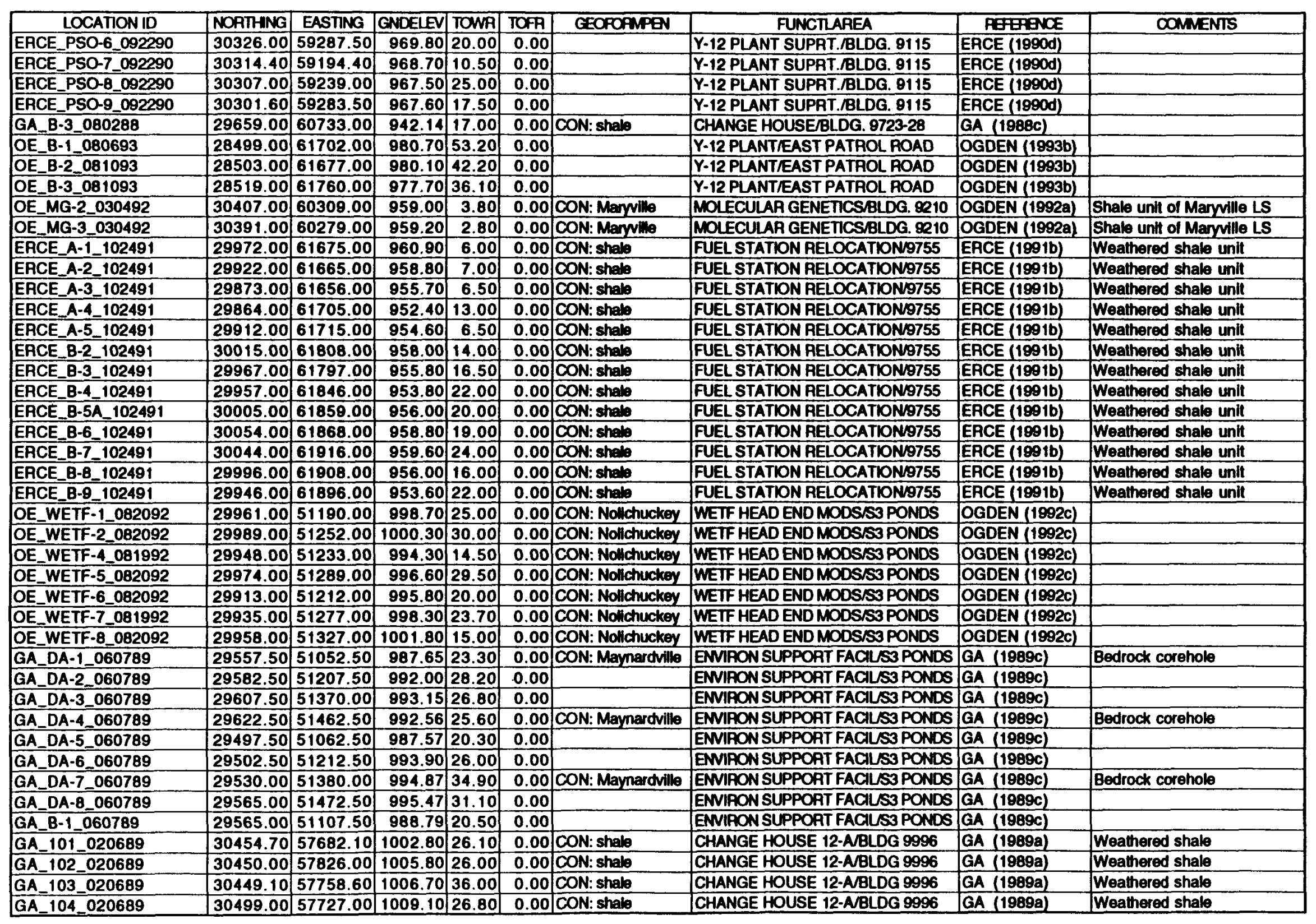




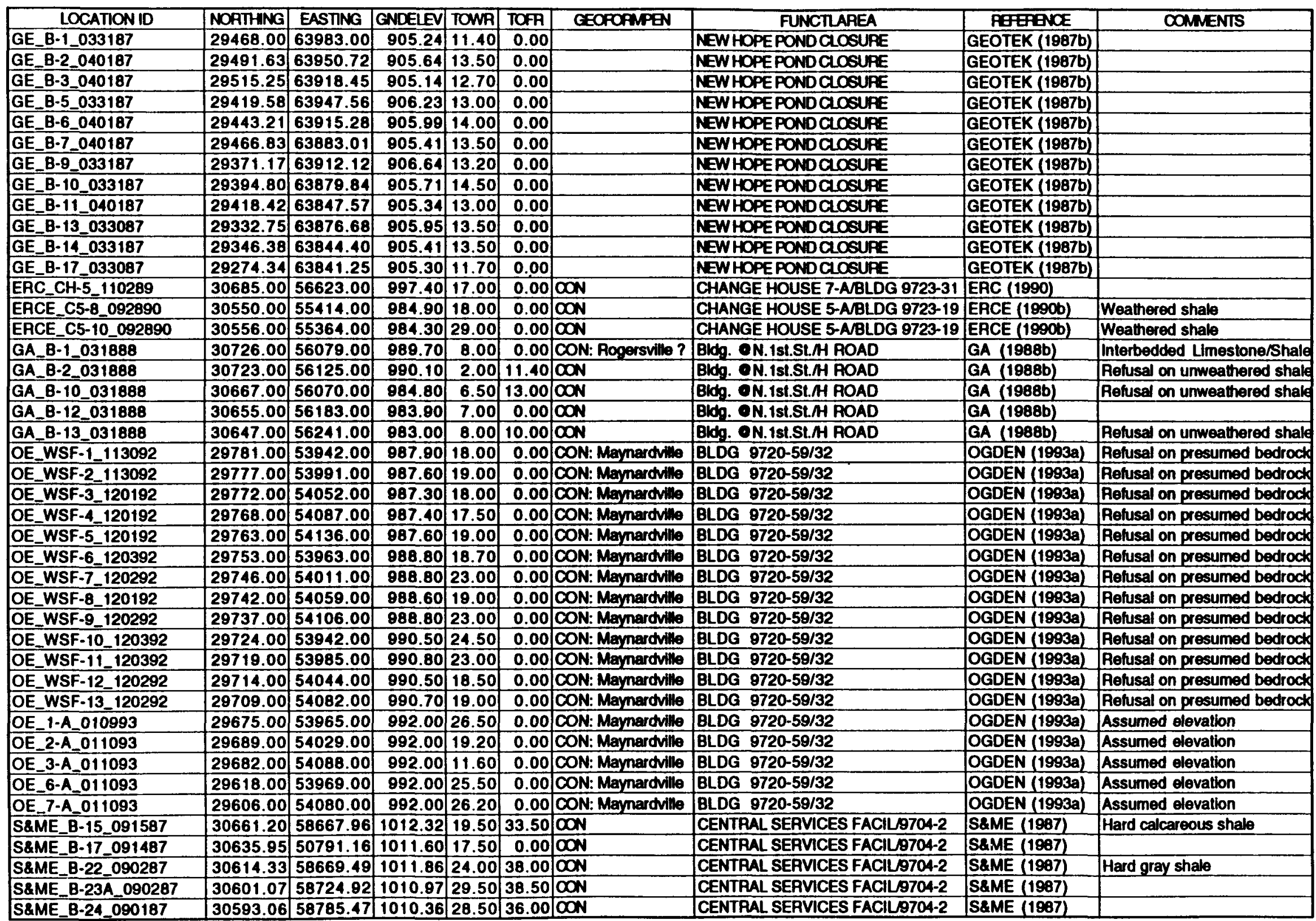


Table A3. Soil Borings Selected for Point Source Data (Continued)

\begin{tabular}{|c|c|c|c|c|c|c|c|c|c|}
\hline LOCATION ID & NOATHING & EASTING & GNDELEV & TOWR & TOFA & GEOPOPMPEN & FUNCTLAREA & PEERGaE & COMMENTS \\
\hline S\&ME_B-25A_090187 & 30584.02 & 58842.95 & 1009.65 & 15.00 & 35.50 & OON & CENTRAL SEAVICES FACIL $9704-2$ & S\&ME (1987) & \\
\hline S\&ME_B-26_090187 & 30576.33 & 58903.06 & 1008.45 & 15.00 & 39.80 & OON & CENTRAL SERVICES FACIL9704-2 & S\&ME (1987) & \\
\hline S\&ME_B-27A_083187 & 30567.09 & 58961.60 & 1006.02 & 25.00 & 37.00 & $\infty$ & CENTRAL SERVICES FACIL9704-2 & S\&ME (1987) & \\
\hline GE_B-3_121886 & 29563.00 & 56919.30 & 954.97 & 11.10 & 0.00 & & SODIUM HYPOCHLOR/BLD 9422-10 & GEOTEK (1987a) & \\
\hline GE_TB-2_\$12984 & 30778.26 & 55891.68 & 1013.15 & 20.25 & 35.70 & & BLDG 9103 ADDITION & GEOTEK (1985) & \\
\hline GE_TB-3_120784 & 30782.75 & 55862.57 & 1013.49 & 16.25 & 22.00 & & BLDG 9103 ADOITION & GEOTEK (1985) & \\
\hline GE_TB-9_113084 & 30686.44 & 55883.93 & 989.29 & 4.00 & 21.50 & & BLDG 9103 ADDITION & GEOTEK (1985) & \\
\hline GA_B-1_112487 & 29565.35 & 51107.16 & 988.79 & 12.00 & 21.50 & & EMMIRON SUPPOAT FACIUTY & GA (1988a) & \\
\hline ERCE_ESF-11_082991 & 29333.00 & 51277.00 & 1003.80 & 27.10 & 0.00 & & ENVIRON SUPPOAT FACIUTY SITE 2 & EACE (1991a) & \\
\hline EACE_ESF-15_082991 & 29351.00 & 51490.00 & 1006.60 & 24.20 & 0.00 & & ENVRON SUPPOAT FACIUTY SITE 2 & EACE (1991a) & \\
\hline ERCE_ESF-16_082991 & 29360.00 & 51544.00 & 1008.00 & 35.50 & 0.00 & & ENVIAON SUPPOAT FACIUTY SITE 2 & EACE (1991a) & \\
\hline GE_B-2_051486 & 28780.50 & 62306.30 & 921.10 & 10.90 & 0.00 & & TRUCK SCALE & GEOTEK (1986) & \\
\hline GE_B-3_051486 & 28773.00 & 62345.60 & 920.90 & 12.50 & 0.00 & & TRUCK SCALE & GEOTEK (1986) & \\
\hline GA_CN-1_021589 & 30377.00 & 59719.00 & 983.00 & 21.20 & 0.00 & $\infty \mathbf{N}$ & Y-12 OAOICN BUILDING/9106 AREA & GA (1989b) & \\
\hline GA_CN-2_021589 & 30374.00 & 59773.00 & 982.10 & 19.00 & 0.00 & $\Phi \mathbf{O N}$ & Y-12 OROICN BUILDING/9106 AREA & GA $(1989 b)$ & \\
\hline GA_CN-3_021589 & 30371.00 & 58832.00 & 981.50 & 21.70 & 0.00 & $\infty \mathbf{O N}$ & Y-12 OROICN BUILDING/9106 AREA & GA (1989b) & \\
\hline GA_CN-4_021589 & 30351.00 & 59694.00 & 979.80 & 17.20 & 0.00 & $\infty$ & Y-12 OROICN BUILDING/9106 AREA & GA (1989b) & \\
\hline GA_CN-5_021589 & 30347.00 & 58800.00 & 977.60 & 22.30 & 0.00 & $\bar{\infty}$ & Y-12 OROICN BUILDING9106 AREA & $G A(1989 b)$ & \\
\hline GA_CN-6_021589 & 30333.00 & 59746.00 & 976.60 & 16.30 & 0.00 & 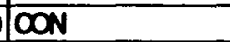 & Y-12 OROICN BUILDING/9106 AREA & GA $(1989 b)$ & \\
\hline GA_CN-7_021589 & 30319.00 & 59832.00 & 972.70 & 18.10 & 0.00 & $\bar{\infty}$ & Y-12 OAOICN BUILDING/9106 AREA & GA (1989b) & \\
\hline GA_CN-8_021589 & 30306.00 & 59796.00 & 973.60 & 17.80 & 0.00 & $\overline{O N}$ & Y-12 OROICN BUILDING/9106 AREA & GA (1989b) & \\
\hline GA_CN-10_021589 & 30265.00 & 59729.00 & 967.80 & 14.60 & 0.00 & $\bar{\infty}$ & Y-12 OROICN BUILDING/9106 AREA & GA (1989b) & \\
\hline GA_CN-11_021589 & 30261.00 & 59768.00 & 967.40 & 13.70 & 0.00 & $\infty$ & Y-12 OROICN BUILDING/9106 AREA & GA (1988b) & \\
\hline GA_CN-17_021589 & 30423.00 & 59710.00 & 988.70 & 24.50 & 0.00 & $\overline{C O N}$ & Y-12 OROICN BUILDING/9106 AREA & GA (1989b) & \\
\hline GA_CN-18_021589 & 30409.00 & 59790.00 & 988.00 & 24.70 & 0.00 & $\bar{\infty}$ & Y-12 OROICN BUILDING/9106 AREA & GA (1989b) & \\
\hline GA_CN-19_021589 & 30405.00 & 58841.00 & 988.30 & 24.80 & 0.00 & $\overline{C O N}$ & Y-12 OAOICN BUILDING/9106 AREA & GA (1989b) & \\
\hline S\&ME_WC-2-B_042689 & 31143.50 & 57943.50 & 1010.21 & 28.00 & 34.50 & & WASTE COOLANT/9409-23 & S\&ME (1989b) & Calcareous shale \\
\hline S\&ME_WC-3-B_050389 & 31121.80 & 57958.10 & 1010.55 & 35.00 & 38.50 & & WASTE COOLANT/9409-23 & S\&ME (1989b) & Calcareous shale \\
\hline S\&ME_WC-5_042689 & $31+31.40$ & 57961.40 & 1010.39 & 30.00 & 36.00 & & WASTE COOLANT/9409:23 & S\&ME (1989b) & \\
\hline S\&ME_WC-6_042589 & 31133.00 & 57990.80 & 1010.33 & 31.00 & 35.00 & & WASTE COOLANT/9409-23 & S\&ME (1989b) & \\
\hline S\&ME_FH-1_030889 & 30280.00 & 57538.00 & 958.30 & 3.00 & 6.00 & & Y-12 FIREHALL97 10-2 & S\&ME (1989a) & Shale w/ limestone lenses \\
\hline ERCE_IP-1_091990 & 29003.00 & 54107.02 & 1058.61 & 53.01 & 0.00 & MOX & LOSTATKC PAESS BUILDING & ERCE (1990C) & \\
\hline ERCE_IP-5_091990 & 28976.00 & 54097.50 & 1060.55 & 27.35 & 0.00 & anox & ISOSTATKC PAESS BUILDING & EACE (1990c) & \\
\hline ERCE_IP-11_091990 & 28948.00 & 54128.00 & 1064.25 & 60.05 & 0.00 & LOX & ISOSTATKC PRESS BUILDING & EACE (1990c) & \\
\hline
\end{tabular}




\begin{tabular}{|c|c|c|c|c|c|c|c|}
\hline LOCATIONID & UNCONSOL & FILLTHK & FILLCONFID & BOTLYRI & DESLYA1 & BOTLYR2 & DESAYPE \\
\hline SAIC_SB-01_091693 & 18.00 & 10.00 & 5 & 6.00 & Clay w/chert Iragments & 10.00 & Clay w/ concrete and chert \\
\hline SAIC_SB-03_092193 & 36.90 & 30.00 & 5 & 1.50 & Topsoll fill w/ cruahed gravel & 6.00 & Clay w/ organics, chert \\
\hline SAIC_SB-04_092293 & 10.90 & 8.00 & 5 & 0.75 & Cruahed gravel & 8.00 & Clay, weathered rock frags, brick trags, plant detritus, black organics \\
\hline SAIC_SB-0B_111693 & 18.00 & 17.50 & 5 & 3.00 & No sample & 8.00 & Clay, shale/cherv/limentone fragments \\
\hline SAIC_SB-11_102693 & 11.30 & 11.30 & 5 & 3.00 & No sample & 9.50 & Clay with chertlimeatone fragments \\
\hline SAIC_SB-14_112993 & 21.10 & 11.00 & 5 & 3.00 & No samplo & 9.00 & Clay, chertimsvshale trags, plant dolritus, mercury \\
\hline SAIC_SB-18_111893 & 12.00 & 12.00 & 5 & 3.00 & No sample & 5.00 & Clay, Imsvehert tragments \\
\hline SAIC_SB-21_101893 & 12.30 & 10.50 & 4 & 3.00 & No sample & 8.00 & Clay, crusher run, Imat/chert tragmenis \\
\hline SAIC_SB-22_101193 & 10.60 & 10.60 & 5 & 3.00 & No sample & 10.00 & Clay, chervshale tragments, organics, plant detrilus, concrete \\
\hline SAIC_SB-26_101893 & 14.30 & 12.50 & 5 & 3.00 & No sample & 3.25 & Crusher run gravel \\
\hline SAIC_SB-33_102593 & 12.50 & 12.50 & 5 & 3.00 & No sample & 9.50 & Clay, Imst/chervshale tragments \\
\hline SAIC_SB-34_102093 & 18.00 & 18.00 & 5 & 3.00 & No samplo & 9.50 & Clay, chorVimavishale frage \\
\hline SAIC_SB-44_101593 & 14.00 & 14.00 & $\mathbf{5}$ & 3.00 & No ample & 7.50 & Clay, kimestone, chert \\
\hline SAIC_SB-45_101493 & 10.20 & 10.20 & 5 & 3.00 & No sample & 7.50 & Clay, cherUlmat fragments \\
\hline SAIC_SB-47_120293 & 11.00 & 11.00 & 4 & 3.00 & No samplo & 7.00 & Clay, cheV/shale/mat Irags \\
\hline SAIC_P.1_100593 & 63.80 & 37.50 & 5 & 9.00 & Clay, Imst/shale/chort frage & 10.00 & Clay, Imstshale/chertwood Iragmente \\
\hline EACE_VC-1_072490 & 12.00 & 10.00 & 5 & 5.50 & Sit, Clay, rock frags & 10.00 & Silty, Cley, shale lrage \\
\hline ERCE_VC-2_072490 & 20.00 & 15.00 & 5 & 15.00 & Clayey ailt w/crushed stone & & \\
\hline ERCE_VC-3_072490 & 17.50 & 17.50 & 5 & 5.50 & Clavey sill, crushed stone & 10.50 & Clayey Silt, woalthered shale \\
\hline ERCE_VC-4_072490 & 19.50 & 19.50 & 5 & 5.50 & Clayey sill, crushed stone & 10.50 & Cleyey Sill, weathered shale trags \\
\hline ERCE_VC-5_072490 & 12.00 & 12.00 & 5 & 5.50 & Clayey all, rock fragments & 12.00 & Clayey Sin, weatherod shalo \\
\hline ERCE_VC-6_072490 & 17.50 & 15.00 & 5 & 10.50 & Clayey sill, rock fragmente & 15.00 & Clayey silt, thate \\
\hline ERCE_VC-7_072490 & 18.00 & 14.50 & 5 & 5.00 & Clayey slli, crushed sione & 9.50 & Clayey Silh, weathered shale \\
\hline ERCE_VC-8_072490 & 18.50 & 14.00 & 5 & 5.50 & Clayey silt, crushed stone & 10.50 & Sill, thale fragments \\
\hline ERCE_VC-9_072490 & 20.50 & 13.50 & 5 & 5.00 & gilt, crushod stone & 8.00 & Sill, weathered shale, crushed stons \\
\hline ERCE_VC-10_072490 & 15.00 & 13.00 & 5 & 3.00 & sill, crushed stone, roole & 5.50 & Silh, chert frags, rools \\
\hline EACE_VC-11_072490 & 19.50 & 11.50 & 5 & 5.00 & silt, crushod atone, rools & 7.50 & Sill, crushed stone \\
\hline ERCE_VC-12_072490 & 20.00 & 12.00 & 5 & 3.00 & sill, crushod atone, chert & 10.00 & Silt, rools, shale lrage \\
\hline OE_EE-2_120992 & 15.00 & 2.50 & 5 & 2.50 & lopsoll, Clay, shale claste & & \\
\hline OE_EE-3_120892 & 15.00 & 2.50 & 5 & 2.50 & lopsoli, docomposed shate & & \\
\hline OE_EE-7_120992 & 14.00 & 2.50 & 5 & 2.50 & Clay whwoa. shale frage & & \\
\hline OE_EE-B_120992 & 9.50 & 2.50 & 5 & 2.50 & Clay w/ woa. shale frags & & \\
\hline$O E \_E E-9 \_120992$ & 9.50 & 2.50 & 5 & 2.50 & Clay w/ wea. shab frags & & \\
\hline OE_PS-5_052992 & 13.00 & 8.00 & 5 & 8.00 & Clayey sith w/rock frage & & \\
\hline OE_PS-12_052992 & 11.50 & 11.50 & 5 & 3.50 & Silt w/rock fragments & 6.00 & Clay with rock fragments \\
\hline OE PS-13_052992 & 8.50 & 6.00 & 5 & 6.00 & Gravely clay w/rock Iraga, roofs & & \\
\hline OE_PS-14_052892 & 20.50 & 12.00 & 5 & 6.00 & Sill w/rock Irags, roots & 12.00 & Clay w/rock fragments \\
\hline OE_PS-15_052892 & 25.50 & 13.50 & 5 & -3.50 & No sample & 13.50 & Clay with rock fragments \\
\hline OE_PS-16_052992 & 26.00 & 24.00 & 5 & 15.50 & Clay with rools, rock fragments & 24.00 & Clay with rock fragments \\
\hline ERCE_PSO-1_092290 & 8.00 & 8.00 & 5 & 8.00 & Sill with shale Iragmente & & \\
\hline ERCE_PSO-3_092290 & 25.00 & 21.00 & 5 & 5.00 & Silt with shale & 10.00 & Sitt with shale, small wood fragments \\
\hline ERCE_PSO-4_092290 & 22.00 & 22.00 & 5 & 7.00 & Sill with shale/brick fragments & 17.00 & Silt with organice, wood, shale lragments \\
\hline ERCE_PSO-5_092290 & 25.00 & 20.00 & 5 & 15.00 & Sill with shate/brick fragmenta & 20.00 & Silt with shale tragments \\
\hline ERCE_PSO-6_092290 & 20.00 & 20.00 & 5 & 12.00 & Silt, limestone/shale tragments & 17.00 & Silt with grass, roots \\
\hline ERCE_PS0.7_092290 & 10.50 & 3.00 & 5 & 3.00 & Sill with rock Iragmonle & & \\
\hline EACE_PSO-8_092290 & 25.00 & 21.50 & 5 & 6.50 & Sill with shale fragmente & 11.50 & Silt with shale/wood tragments \\
\hline ERCE_PSO-9_092290 & 17.50 & 17.50 & 5 & 6.50 & Sill with shale & 17.50 & Sill with wood/shale iragmenis (probable rock at 17.5 BGS) \\
\hline GA_B-3_0802B8 & 17.50 & 5.00 & 5 & 5.00 & Clayey silt & & \\
\hline$O E, 8-1,080693$ & 53.20 & 16.50 & 5 & 1.00 & Asphalt, crushed stone & 3.00 & Crushed stone, silt, clay, rock/wood fragments \\
\hline OE 8.2081093 & 42.20 & 17.70 & 5 & 2.00 & Topsoil, crushed stone, clay, wood & 7.50 & Cley, weathered shale tregments, wood chips \\
\hline
\end{tabular}


Table A4. Soil Boring Point Source Data Fill Characteristics (Continued)

\begin{tabular}{|c|c|c|c|c|}
\hline LOCATION ID & BOILYA & DESLYYB & BOTLYA4 & DESLYRA \\
\hline \multicolumn{5}{|l|}{ SAIC_SB-01_091693 } \\
\hline SAIC_SB-03_092193 & 15.50 & Clay, black sand, large brick frapmenls, mortar, copper wire & 30.50 & Clay, brick hagmenis, shaio clasts, organics \\
\hline \multicolumn{5}{|l|}{ SAIC_SB-04_092293 } \\
\hline SAIC_SB-08_111693 & 13.00 & Clay, shale/limestone frags, brick trags, plant detritus & 17.50 & Clay, shale/limesione Irags, wood frags, nail \\
\hline SAIC_SB-11_102693 & 11.30 & Clay, brick frags, limentone/chale trags, plant detritus & & \\
\hline SAIC_SB-14_112993 & 11.00 & Clay, plant detrilus, naile, mercury, imstrehalo tragments & & \\
\hline SAIC_SB-18_111893 & 9.50 & Clay w/50\% shals, plant detritus, wood, brick hage, nall & 11.00 & Clay, $30 \%$ shale \\
\hline SAIC_SB-21_101893 & 9.00 & Clay, shale/imstchert frage, asphalt, molal tragmente & 9.50 & Clay, $10 \%$ chert \\
\hline SAIC_SB-22_101193 & 10.50 & Clay, chent, shale, limestone Iregmente & 11.50 & Clay, plant detritus, black organics, weathered shalo \\
\hline \multicolumn{5}{|l|}{ SAIC_SB-26_101893 } \\
\hline SAIC_SB-33_102593 & 12.50 & Clay, $75 \%$ Imst trags, asphatt frage, molal shavinges & & \\
\hline SAIC_SB-34_102093 & 11.00 & Clay, $70 \%$ Imsl lrags, shale, brick & 13.00 & Clay, shale/chert/mst70\% rock frags, asphail \\
\hline SAIC_SB-44_101593 & 9.00 & Clay, Imsv/shalo/chert frags, large brick fragments & 12.50 & Clay, shalo, possiblo calcareous mortar \\
\hline SAIC_SB-45_101493 & 10.20 & Clay, Imsvchert Irags, brick, poseible mortar & & \\
\hline SAIC_SB.47_120293 & 9.00 & Limesione fragments and crushed limeatone powder & 11.00 & Clay, wood trags, shalofmst frags \\
\hline SAIC_P-1_100593 & 17.00 & Clay, wood, chent, shale, limestone, bricks & 18.00 & Clay, limestone Iragmente \\
\hline \multicolumn{5}{|l|}{ ERCE_VC-1_072490 } \\
\hline \multicolumn{5}{|l|}{ ERCE_VC-2_072490 } \\
\hline ERCE_VC-3_072490 & 17.50 & Clayey Silt, roote & & \\
\hline ERCE_VC-4_072490 & 15.00 & Silt, thale frags, rools & 19.50 & Silt, shale trags \\
\hline \multicolumn{5}{|l|}{ ERCE_VC-5_072490 } \\
\hline \multicolumn{5}{|l|}{ ERCE_VC-6_072490 } \\
\hline ERCE_VC.7.072490 & 14.50 & Sitt, weathered shale & & \\
\hline EACE_VC-8_072490 & 14.00 & Silt, shale fragments & & \\
\hline ERCE_VC-9_072490 & 10.50 & Weathered shate & 13.50 & Clayey sill, chert/shalo Iragments \\
\hline ERCE_VC-10_072490 & 13.00 & Silt, shalo frage & & \\
\hline ERCE_VC-11_072490 & 11.50 & Sit, weathered shale & & \\
\hline EACE_VC-12_072490 & 12.00 & Silt, woathered shale & & \\
\hline \multicolumn{5}{|l|}{ OE_EE-2_120992 } \\
\hline \multicolumn{5}{|l|}{ OE_EE-3_120892 } \\
\hline \multicolumn{5}{|l|}{ OE_EE-7_120992 } \\
\hline \multirow{2}{*}{\multicolumn{5}{|c|}{ OE_EE-B_120992 }} \\
\hline \multirow{2}{*}{\multicolumn{5}{|c|}{$\begin{array}{l}\text { OE_EE-9_120992 } \\
\text { OE_PS-5_052992 }\end{array}$}} \\
\hline & & & & \\
\hline OE_PS-12_052992 & 11.50 & Probable fill material & & \\
\hline \multicolumn{5}{|l|}{ OE_PS-13_052992 } \\
\hline \multicolumn{5}{|l|}{ OE_PS-14_052892 } \\
\hline \multicolumn{5}{|l|}{ OE_PS-15_052892 } \\
\hline \multicolumn{5}{|l|}{ OE_PS-16_052992 } \\
\hline \multicolumn{5}{|l|}{ ERCE_PSO_1_092290 } \\
\hline ERCE_PSO-3_092290 & 17.00 & Silt with shale & 21.00 & Silty clay \\
\hline EACE_PSO-4_092290 & 22.00 & Silt with roots, shale fragments & & \\
\hline \multicolumn{5}{|l|}{ ERCE_PSO-5_092290 } \\
\hline EACE_PSO-6_092290 & 20.00 & Silt & & \\
\hline \multicolumn{5}{|l|}{ ERCE_PSO-7_092290 } \\
\hline ERCE_PSO-8_092290 & 16.50 & Silt with shale fragments & 21.50 & Sill with wood/shale Iragmenls \\
\hline \multicolumn{5}{|l|}{ ERCE_PSO-9_092290 } \\
\hline \multicolumn{5}{|l|}{ GA_B-3_08028B } \\
\hline OE_B-1_080693 & 4.50 & Clay, rock fragments & 6.50 & Crushed stone, silt \\
\hline OE_B-2_0B1093 & 9.90 & Black sand & 15.40 & Clay with rools, rock tragments \\
\hline
\end{tabular}


Table A4. Soil Boring Point Source Data Fill Characteristics (Continued)

\begin{tabular}{|c|c|c|c|c|}
\hline \multirow{2}{*}{\begin{tabular}{|c|} 
LOCATION ID \\
SAIC_SB-01_091693 \\
\end{tabular}} & BOTYYA5 & DESLYAS & BOTLYR6 & DESLYPB \\
\hline & & & & \\
\hline \multirow{2}{*}{\multicolumn{5}{|c|}{ 34.00 Clay, black organics, chert lrags }} \\
\hline & & & & \\
\hline \multirow{2}{*}{\multicolumn{5}{|c|}{$\begin{array}{l}\text { SAIC_SB-0B_111693 } \\
\text { SAIC_SB-11_102693 }\end{array}$}} \\
\hline & & & & \\
\hline \multicolumn{5}{|l|}{ SAIC_SB-14_112993 } \\
\hline SAIC_SB-18_111893 & 12.00 & Clay, 20\% shale, wood, concrete w/quartz pebbles & & \\
\hline SAIC_SB-21_101893 & 10.50 & Clay. Imstshala/chert frags, apparent asboatos libers & & \\
\hline SAIC_SB-22_101193 & 12.50 & Clay with asphall, chert fragments & & \\
\hline \multicolumn{5}{|l|}{ SAIC_SB-26_101893 } \\
\hline \multicolumn{5}{|l|}{ SAIC_SB-33_102593 } \\
\hline SAIC_SB-34_102093 & 14.50 & Clay, shalo/cherthmsVrock frags, mortar, asphalt, wood trags & 15.00 & Clay, shalo, Imst lirags \\
\hline SAIC_SB-44_101593 & 14.00 & Clay, chorllimat lrags, brick, concrete, wood & & \\
\hline \multicolumn{5}{|l|}{ SAIC_SB-45_101493 } \\
\hline \multicolumn{5}{|l|}{ SAIC_SB-47_120293 } \\
\hline SAIC_P-1_100593 & 21.50 & Limestone, sparse wood fragments & 26.00 & Clay, woodimst/ahale Irags, nall \\
\hline \multicolumn{5}{|l|}{ EACE_VC-1_072490 } \\
\hline \multirow{2}{*}{\multicolumn{5}{|c|}{\begin{tabular}{|l|} 
ERCE_VC-2_072490 \\
ERCE_VC-3 072490
\end{tabular}}} \\
\hline ERCE_VC-3_072490 & & & & \\
\hline \multicolumn{5}{|l|}{ ERCE_VC-4_072490 } \\
\hline \multicolumn{5}{|l|}{ EACE_VC-5_072490 } \\
\hline \multicolumn{5}{|l|}{ ERCE_VC-6_072490 } \\
\hline \multicolumn{5}{|l|}{ ERCE_VC-7_072490 } \\
\hline \multicolumn{5}{|l|}{ EACE_VC-8_072490 } \\
\hline \multirow{2}{*}{\multicolumn{5}{|c|}{$\begin{array}{l}\text { EACE_VC-9.072490 } \\
\text { EACE VC-10 } 072490\end{array}$}} \\
\hline \multirow{2}{*}{\multicolumn{5}{|c|}{$\begin{array}{l}\text { ERCE_VC-10_072490 } \\
\text { ERCE_VC-11_072490 }\end{array}$}} \\
\hline & & & & \\
\hline \multicolumn{5}{|l|}{ EACE_VC-12_072490 } \\
\hline \multicolumn{5}{|l|}{ OE_EE-2_120992 } \\
\hline \multicolumn{5}{|l|}{ OE_EE-3_120892 } \\
\hline \multicolumn{5}{|l|}{ OE_EE-7_120992 } \\
\hline OE_EE-8_120992 & & & & \\
\hline OE_EE-9_120992 & & & & \\
\hline OE_PS-5_052992 & & & & \\
\hline OE_PS-12_052992 & & & & \\
\hline OE_PS-13_052992 & & & & \\
\hline OE_PS-14_052892 & & & & \\
\hline OE_PS-15_052892 & & & & \\
\hline OE_PS.16_052992 & & & & \\
\hline ERCE_PSO-1_092290 & & & & \\
\hline ERCE_PSO-3_092290 & & & & \\
\hline ERCE PSO-4_092290 & & & & \\
\hline EACE_PSO-5_092290 & & & & \\
\hline ERCE_PSO-6_092290 & & & & \\
\hline EACE PSO-7_092290 & & & & \\
\hline ERCE_PSO-8_092290 & & & & \\
\hline EACE_PSO-9_092290 & & & & \\
\hline GA_B-3_080288 & & & & \\
\hline OE_B-1_080693 & 8.50 & Black sand & 15.00 & Black sand w/rock fragments \\
\hline OE B-2 081093 & 15.50 & Sendstone fragments & 16.40 & Clay with rock fragments \\
\hline
\end{tabular}


Table A4. Soil Boring Point Source Data Fill Characteristics (Continued)

\begin{tabular}{|c|c|c|c|c|c|c|}
\hline LOCATIONID & BOTLYA7 & DESLYR7 & BOTLYRE & DESLYRA & BOTLYF9 & DESLYPO \\
\hline \multicolumn{7}{|l|}{ SAIC_SB-01_091693 } \\
\hline \multirow{2}{*}{\multicolumn{7}{|c|}{ SAIC_SB-03_092193 }} \\
\hline & & & & & & \\
\hline \multicolumn{7}{|l|}{ SAIC_SB-08_111693 } \\
\hline \multicolumn{7}{|l|}{ SAIG_SB-11_102693 } \\
\hline \multirow{2}{*}{\multicolumn{7}{|c|}{\begin{tabular}{|l|} 
SAIC_SB-14_112993 \\
SAIC_SB-18_111893
\end{tabular}}} \\
\hline & & & & & & \\
\hline \multicolumn{7}{|l|}{ SAIC_SB-21_101893 } \\
\hline \multicolumn{7}{|l|}{ SAIC_SB-22_101193 } \\
\hline \multicolumn{7}{|l|}{ SAIC_SB-26_101893 } \\
\hline \multicolumn{7}{|l|}{ SAIC_SB-33_102593 } \\
\hline SAIC_SB-34_102093 & 17.00 & Clay, shale, Imst irags, apparent roofing shinglo & 18.00 & Clay, shmmst Iregs, plant detritus, brick Irags, black shaib & & \\
\hline \multicolumn{7}{|l|}{ SAIC_SB-44_101593 } \\
\hline \multicolumn{7}{|l|}{ SAIC_SB-45_101493 } \\
\hline \multicolumn{7}{|l|}{ SAIC_SB-47_120293 } \\
\hline SAIC_P-1_100593 & 32.50 & Clay, brick, particle boerd frags, concrele, molal frags & 37.50 & Clay, limesione, two (2) pieces clear plastic, wood trags & & \\
\hline \multicolumn{7}{|l|}{ ERCE_VC-1_072490 } \\
\hline \multicolumn{7}{|l|}{ ERCE_VC-2_072490 } \\
\hline \multirow{2}{*}{\multicolumn{7}{|c|}{$\begin{array}{l}\text { EACE_VC-3_072490 } \\
\text { EACEVVC-4 } 072490\end{array}$}} \\
\hline \multirow{2}{*}{\multicolumn{7}{|c|}{$\begin{array}{l}\text { ERCE_VC-4_072490 } \\
\text { EACE_VC-5_072490 }\end{array}$}} \\
\hline & & & & & & \\
\hline \multirow{2}{*}{\multicolumn{7}{|c|}{$\begin{array}{l}\text { EACE_VC-6_072490 } \\
\text { ERCE VC-7 072490 }\end{array}$}} \\
\hline \multirow{2}{*}{\multicolumn{7}{|c|}{$\begin{array}{l}\text { ERCE_VC-7_072490 } \\
\text { ERCE_VC-8_072490 }\end{array}$}} \\
\hline \multicolumn{2}{|l|}{ ERCE_VC-8_072490 } & & & & & \\
\hline ERCE_VC-9_072490 & & & & & & \\
\hline ERCE_VC-10_072490 & & & & & & \\
\hline ERCE_VC-11_072490 & & & & & & \\
\hline EACE_VC.12_072490 & & & & & & \\
\hline OE_EE-2_120992 & & & & & & \\
\hline OE_EE-3_120892 & & & & & & \\
\hline OE_EE.7_120992 & & & & & & \\
\hline OE_EE-8_120992 & & & & & & \\
\hline OE_EE-9_120992 & & & & & & \\
\hline OE_PS.5_052992 & & & & & & \\
\hline OE_PS-12_052992 & & & & & & \\
\hline OE_PS-13_052992 & & & & & & \\
\hline OE_PS-14_052892 & & & & & & \\
\hline OE_PS-15_052892 & & & & & & \\
\hline OE_PS.16_052992 & & & & & & \\
\hline ERCE_PSO-1_092290 & & & & & & \\
\hline ERCE_PSO-3_092290 & & & & & & \\
\hline ERCE_PSO-4_092290 & & & & & & \\
\hline ERCE PSO-5 092290 & & & & & & \\
\hline ERCE_PSO-6_092290 & & & & & & \\
\hline ERCE_PSO-7_092290 & & & & & & \\
\hline ERCE_PSO-8_092290 & & & & & & \\
\hline ERCE_PSO-9_092290 & & & & & & \\
\hline GA_B-3_080288 & & & & & & \\
\hline$O E, B \cdot 1 \ldots 080693$ & 16.50 & Clay with chert & & & & \\
\hline OE_B-2_081093 & 17.00 & Black sand & 17.20 & Clay with rock fragments & 17.70 & Black sand \\
\hline
\end{tabular}




\begin{tabular}{|c|c|c|c|c|c|c|c|}
\hline LOCATIONID & Unconsal & FILITHK & FILLCONFID & BOTLYA1 & DESLYR1 & BBOTLYA2 & DESLYPQ \\
\hline OE_B-3_081093 & 36.10 & 19.00 & 5 & 1.00 & Asphall, crushed sione & 3.00 & Crushed stono, clay, rock fragmente \\
\hline$\overline{O E} \_M G-2 \_030492$ & 3.80 & 2.50 & 5 & 2.50 & Topsoil, sill, rools, wear thate frags, cruahed slone & & \\
\hline OE_MG-3_030492 & 2.80 & 2.50 & 5 & 2.50 & Topsoll, silt, rools, woe. shate traps, crushed slone & & \\
\hline ERCE_A-1_102491 & 6.00 & 2.00 & 5 & 2.00 & Topsoli, sill, thalehimestone fragments & & \\
\hline ERCE_A-2_102491 & 7.00 & 2.00 & 5 & 2.00 & Topsoll, sill, shalenimestone fragments & & \\
\hline ERCE_A-3_102491 & 6.50 & 2.00 & 5 & 2.00 & Topsoil, sill, shale/limesione fragments & & \\
\hline ERCE_A.4_102491 & 13.00 & 11.00 & 5 & 11.00 & Topsoil, silt, crushed stone, shale Iragments & & \\
\hline ERCE_A-5_102491 & 6.50 & 1.00 & 5 & 1.00 & Topsoil, elli, limestone frapments & & \\
\hline ERCE_B-2_102491 & 14.00 & 3.00 & 5 & 2.00 & Asphalt, crushed stone & 3.00 & Sith, shale Iragments \\
\hline ERCE_B-3_102491 & 16.50 & 16.50 & 5 & 1.50 & Asphalt, crushed atone & 10.50 & Sili, shale Iragments \\
\hline EACE_B-4_102491 & 22.00 & 17.00 & 5 & 2.00 & Crushed stone & 13.00 & Sith with woathered strale \\
\hline EACE_B-5A_102491 & 20.00 & 14.50 & 5 & 1.50 & Crushed atone & 14.50 & Sit, shalo Iragments \\
\hline ERCE_B-6_102491 & 19.00 & 14.00 & 5 & 2.00 & Crushed atone & 14.00 & Silt, shait fragments, roote \\
\hline EACE 8-7 102491 & 24.00 & 14.50 & 5 & 2.50 & Crushed stone & 14.50 & Sit, shale Iragments \\
\hline ERCE_B-8_102481 & 16.00 & 16.00 & 5 & 2.50 & Crushed atone & 11.00 & Sili, shale fragments \\
\hline ERCE_8-9_102491 & 22.00 & 14.00 & 5 & 2.00 & Crushed stone & 8.00 & Silt, shale/imestone fragments \\
\hline OE_WETF-1_082092 & 25.00 & 12.50 & 5 & 3.00 & Crushed stone, sand, cley, rock fragments & 5.00 & Clayey sand, rock Iragments, weathered thale Iragments \\
\hline OE_WETF-2_082092 & 30.00 & 8.50 & 5 & 2.50 & Topsoll, clay, rock/brick Iragments, roots & 4.00 & Decomposed shale, weathered shats fragments \\
\hline OE_WETF-4_081992 & 14.50 & 5.00 & 5 & 2.50 & Clay, rock fregmonls & 5.00 & Clay, rock tragments, rools \\
\hline OE_WETF-5_082092 & 29.50 & 9.00 & 5 & 5.00 & Clay, rock frapmenls, rools, orass & 7.50 & Clay, rock fragments, roote, grase, wood \\
\hline OE_WETF-8_082092 & 20.00 & 12.50 & 5 & 3.00 & Clay, rock fragments, crushed stone & 5.00 & Clayey gravel \\
\hline OE_WETF.7_081992 & 23.70 & 10.50 & 5 & 7.50 & Clayey sand, rock frapments, cruahed stone, rools & 10.50 & Sandy clay, rock Iragments, wood \\
\hline OE_WETF-8_082092 & 15.00 & 10.00 & 5 & 1.10 & Asphall, crushed atone & 10.00 & Clay, rock tragments, etraw \\
\hline GA_DA-1_060789 & 23.30 & 11.00 & 5 & 3.50 & Silt w/cinders, limestone/shale fragments & 6.50 & Silty clay w/ llmesione frapments \\
\hline GA_DA-2_0607B9 & 28.20 & 12.50 & 5 & 12.50 & Silfy clay w/ehaleflimedione tragmente & & \\
\hline GA_DA-3_060789 & 26.80 & 11.00 & 5 & 5.50 & Clayey eith w/shalo fragments & 11.00 & Silty clay w/limesione/chale tragments. vegotation traces \\
\hline GA_DA-4_060789 & 25.60 & 10.00 & 5 & 8.00 & Silty clay w/shale/imeatone tragmenls & 10.00 & Shale/wood tragmente w/clay \\
\hline GA_DA-5_060789 & 20.30 & 10.50 & 5 & 3.00 & Decomposed shate wilmestone fragments & 7.00 & Clay with dap \\
\hline GA_DA-6_060789 & 26.00 & 12.50 & 5 & 5.00 & Decomposed thate, clayer silt & 7.50 & Silty clay with shalo frepments \\
\hline GA_DA-7_060789 & 34.90 & 10.00 & 5 & 3.00 & Decomposed thate with clay & 10.00 & Sility clay with shale/chert tragments \\
\hline GA_DA-8_060789 & 31.10 & 9.00 & 5 & 9.00 & Silty clay w/limestone/shale/chert Irags, vegolation & & \\
\hline GA_B-1_060789 & 20.50 & 11.50 & 5 & 3.50 & Topsoil, silty clay with rock frapments & 8.50 & Silly clay with rock fragments, organic material \\
\hline GA_101_020689 & 26.10 & 15.50 & 5 & 2.00 & Topsoll, crushed stone & 7.00 & Clayey silt with rock fragments \\
\hline GA_102_020689 & 26.00 & 16.50 & 5 & 2.00 & Topsoll, crushod atone, allt & 15.50 & Silty clay with weathered chale fragments \\
\hline GA_103_020689 & 36.00 & 25.00 & 5 & 4.00 & Silty clay with weathered rock fragments & 13.50 & Silty clay with rock fragments \\
\hline GA_104_020689 & 26.80 & 18.50 & 5 & 8.00 & Clayey silt with rock/shale tragments & 12.50 & Silty clay \\
\hline GE_B.1_033187 & 11.40 & 11.40 & 5 & 2.00 & Organic matorial & 10.00 & Silly clay with chert fragments, organic silt \\
\hline GE_B-2_040187 & 13.50 & 9.00 & 5 & 5.00 & Clay with chert fragments, organic sill & 7.50 & Silty clay \\
\hline GE_B-3_040187 & 12.70 & 6.00 & 5 & 6.00 & Sily clay with chert fragments & & \\
\hline GE_B.5_033187 & 13.00 & 7.00 & 5 & 7.00 & Silty clay with weathered shale, chert, organics & & \\
\hline GE_B-6_040187 & 14.00 & 5.00 & 5 & 5.00 & Silty clay with weathered shale, chen, asphalt trags & & \\
\hline GE_B.7_040187 & 13.50 & 3.00 & 5 & 3.00 & Silty clay with chert, topsoil & & \\
\hline GE_B-9_033187 & 13.20 & 9.50 & 5 & 5.00 & Silty clay with weathered shale, rools & 8.00 & Clay with chert \\
\hline GE_B-10_033187 & 14.50 & 10.00 & 5 & 4.00 & Silty clay with woalhered shale & 10.00 & Silty clay with chert \\
\hline GE_B.11_040187 & 13.00 & 7.50 & 5 & 7.50 & Silty clay with chert, roots & & \\
\hline GE_B-13_033087 & 13.50 & 3.00 & 5 & 3.00 & Organic material with silly clay, chen, topsoil & & \\
\hline GE_B-14_033187 & 13.50 & 9.50 & 5 & 4.00 & Clay with chert & 7.00 & Silly clay with chert \\
\hline GE_B-17_033087 & 11.70 & 4.00 & 5 & 4.00 & Silty clay, chert, organic malerial & & \\
\hline EAC_CH-5_110289 & 17.00 & 4.50 & 4 & 4.50 & Probable fill of sandy sill with chen Iragments & & \\
\hline ERCE_C5-8_092890 & 18.00 & 18.00 & 4 & 5.00 & Concrete, crushed slone & 18.00 & Shale Iragments \\
\hline
\end{tabular}


Table A4. Soil Boring Point Source Data Fill Characteristics (Continued)

\begin{tabular}{|c|c|c|c|c|}
\hline LOCATION ID & BOTLYYR & DESLYRS & BOTLYA4 & DESEYRA \\
\hline OE_B-3_081093 & 6.50 & Clay, rock tragments & 18.10 & Black sand, rock Iragmente \\
\hline \multirow{2}{*}{\multicolumn{5}{|c|}{ OE_MG-2_030492 }} \\
\hline \multicolumn{4}{|l|}{ OE_MG-3_030492 } & \\
\hline \multicolumn{5}{|l|}{ ERCE_A-1_102491 } \\
\hline \multicolumn{5}{|l|}{ ERCE_A-2_102491 } \\
\hline \multicolumn{5}{|l|}{ ERCE_A-3_102491 } \\
\hline \multicolumn{5}{|l|}{ ERCE_A-4_102491 } \\
\hline \multicolumn{5}{|l|}{ ERCE_A-5_102491 } \\
\hline \multicolumn{5}{|l|}{ EACE_B-2_102491 } \\
\hline ERCE_B-3_102491 & 16.50 & Silt & & \\
\hline EACE_B-4_102491 & 17.00 & Silt with rools & & \\
\hline \multicolumn{5}{|l|}{ ERCE_B-5A_102491 } \\
\hline \multicolumn{5}{|l|}{ ERCE_B-6_102491 } \\
\hline \multicolumn{5}{|l|}{ ERCE_B-7_102491 } \\
\hline ERCE_B-8_102491 & 16.00 & Weathered shale, large gravel & & \\
\hline ERCE_B-9,102491 & 14.00 & Silh, weathered thale & & \\
\hline OE_WETF-1_082092 & 12.50 & Clay, rock Iragments & & \\
\hline OE_WETF-2_082092 & 8.50 & Cruetred slone & & \\
\hline \multicolumn{5}{|l|}{ OE_WETF-4_081892 } \\
\hline OE_WETF-5_002092 & 9.00 & Clay, rock frapments, rools, orass, weathered shale & & \\
\hline OE_WETF-6_082092 & 10.00 & Clay, rock frapments & 12.50 & Sandy clay, rock frapmente, wood \\
\hline \multicolumn{5}{|l|}{ OE_WETF-7_081892 } \\
\hline \multicolumn{5}{|l|}{ OE WETF-8_082092 } \\
\hline GA_DA-1_060789 & 9.00 & Decomposed shale, limestone, cindere w/clayey silf & 11.00 & Silly clay w/shale fregments \\
\hline \multicolumn{5}{|l|}{ GA_DA-2_060789 } \\
\hline \multicolumn{5}{|l|}{ GA_DA-3_060789 } \\
\hline \multicolumn{5}{|l|}{ GA_DA-4_060789 } \\
\hline GA_DA-5_060789 & 9.50 & Silly clay whimestone/wood tragments & 10.50 & Clayey silt with ashes \\
\hline GA_DA-6_060789 & 11.00 & Decomposed shale, clayey silt with limestons fragments & 12.50 & Concrete Iragments \\
\hline \multicolumn{5}{|l|}{ GA_DA-7_060789 } \\
\hline \multicolumn{5}{|l|}{ GA_DA-8_060789 } \\
\hline GA_B-1_060789 & 11.50 & Silty clay with weathered shale fragments & & \\
\hline GA_101_020689 & 13.00 & Silty clay with rock tragmenta & 15.50 & Silty clay with wood/rock Iragments \\
\hline GA_102_020689 & 16.50 & Silty clay with organic material & & \\
\hline GA_103_020689 & 20.50 & Silty cley with rock fragmenls, organic material & 25.00 & Silly clay with rock fragments, wood \\
\hline GA_104_020689 & 18.50 & Silty clay with crushod sione fragments & & \\
\hline GE_B-1_033187 & 11.40 & Silty clay with weathered shale, small roots & & \\
\hline GE_B-2_040187 & 9.00 & Silty clay with small roots & & \\
\hline \multicolumn{5}{|l|}{ GE_B-3_040187 } \\
\hline \multicolumn{5}{|l|}{ GE_B-5_033187 } \\
\hline GE_B-6_040187 & & & & \\
\hline GE_B-7_040187 & & & & \\
\hline GE_B-9_033187 & 9.50 & Silty clay with chert & & \\
\hline GE_B-10_033187 & & & & \\
\hline GE_B-11_040187 & & & & \\
\hline GE_B-13_033087 & & & & \\
\hline GE_B-14_033187 & 9.50 & Silty clay with weathered shale & & \\
\hline GE_B.17_033087 & & & & \\
\hline ERC_CH-5_110289 & & & & \\
\hline ERCE_C5-8_092890 & & & & \\
\hline
\end{tabular}


Table A4. Soil Boring Point Source Data Fill Characteristics (Continued)

\begin{tabular}{|c|c|c|c|c|}
\hline LOCATION ID & BOIYYR5 & DESLYA5 & BOTLYF6 & DESLYF6 \\
\hline OE_8-3_081093 & 19.00 & Clay, rock Iragments & & \\
\hline \multicolumn{5}{|l|}{ OE_MG-2_030492 } \\
\hline \multicolumn{5}{|l|}{ OE_MG-3_030492 } \\
\hline \multicolumn{5}{|l|}{ ERCE_A-1_102491 } \\
\hline \multirow{2}{*}{\multicolumn{5}{|c|}{\begin{tabular}{|l} 
ERCE_A-2_102491 \\
ERCE A-3 102491
\end{tabular}}} \\
\hline \multirow{2}{*}{\multicolumn{5}{|c|}{$\frac{\text { ERCE_A-3_102491 }}{\text { ERCE_A-4_102491 }}$}} \\
\hline & & & & \\
\hline \multicolumn{5}{|l|}{ ERCE A-5_102491 } \\
\hline \multirow{2}{*}{\multicolumn{5}{|c|}{ ERCE_B-2_102491 }} \\
\hline & & & & ERCE B-3_102491 \\
\hline \multicolumn{5}{|l|}{ ERCE_B-4_102491 } \\
\hline \multirow{2}{*}{\multicolumn{5}{|c|}{ ERCE_B-5A_102491 }} \\
\hline & & & & \\
\hline \multicolumn{3}{|l|}{$\begin{array}{l}\text { ERCE_B-6_102491 } \\
\text { ERCE_B-7_102491 }\end{array}$} & & \\
\hline \multicolumn{5}{|l|}{ EACE_B-B_102491 } \\
\hline \multirow{2}{*}{\multicolumn{5}{|c|}{ EACE_B-9_102491 }} \\
\hline \multirow{2}{*}{\multicolumn{2}{|c|}{$\begin{array}{l}\text { OE_WETF-1_082092 } \\
\text { OE WETF-2 } 082092\end{array}$}} & & & \\
\hline & & & & \\
\hline \multicolumn{5}{|l|}{ OE_WETF-4_081992 } \\
\hline \multicolumn{5}{|l|}{ OE_WETF-5_082092 } \\
\hline \multicolumn{5}{|l|}{ OE_WETF-6_082092 } \\
\hline \multicolumn{5}{|l|}{ OE_WETF-7_081992 } \\
\hline \multirow{2}{*}{\multicolumn{5}{|c|}{ OE_WETF-8_082092 }} \\
\hline \multirow{2}{*}{\multicolumn{5}{|c|}{$\frac{\text { GA_DA-1_060789 }}{\text { GA_DA-2_060789 }}$}} \\
\hline & & & & \\
\hline \multicolumn{5}{|l|}{ GA_DA-3_060789 } \\
\hline GA_DA-4_060789 & & & & \\
\hline GA_DA-5 060789 & & & & \\
\hline QA_DA-6_060789 & & & & \\
\hline GA_DA-7_060789 & & & & \\
\hline GA_DA-8_060789 & & & & \\
\hline GA_B-1_060789 & & & & \\
\hline GA_101_020689 & & & & \\
\hline GA_102_020689 & & & & \\
\hline QA_103_020689 & & & & \\
\hline GA_104_020689 & & & & \\
\hline GE_8-1_033187 & & & & \\
\hline GE_B-2_040187 & & & & \\
\hline$\overline{G E} B-3 \_040187$ & & & & \\
\hline GE B-5_033187 & & & & \\
\hline GE_B-6_040187 & & & & \\
\hline GE_B-7_040187 & & & & \\
\hline GE_B-9_0331B7 & & & & \\
\hline GE_B-10_033187 & & & & \\
\hline GE_B-11_040187 & & & & \\
\hline GE_B-13_033087 & & & & \\
\hline GE_B-14_033187 & & & & \\
\hline GE_B.17_033087 & & & & \\
\hline EAC_CH-5_110289 & & & & \\
\hline ERCE_C5-8_092890 & & & & \\
\hline
\end{tabular}


Table A4. Soil Boring Point Source Data Fill Characteristics (Continued)

\begin{tabular}{|c|c|c|c|c|c|c|}
\hline LOCATIONID & BOTLYAT & DESLYA7 & BOTLYR & DESLYRB & BOTLYPO & DESLYPO \\
\hline \multirow{2}{*}{\multicolumn{7}{|c|}{ OE_B-3_081093 }} \\
\hline \multicolumn{6}{|l|}{ OE_MG-2,030492 } & \\
\hline \multicolumn{7}{|l|}{ OE_MG-3_030492 } \\
\hline \multirow{2}{*}{\multicolumn{7}{|c|}{\begin{tabular}{|l|} 
ERCE_A-1_102491 \\
EACE_A-2_102491
\end{tabular}}} \\
\hline & & & & & & \\
\hline \multicolumn{7}{|l|}{ EACE_A.3_102491 } \\
\hline \multicolumn{7}{|l|}{ ERCE_A-4_102491 } \\
\hline \multirow{2}{*}{\multicolumn{7}{|c|}{\begin{tabular}{|l|} 
ERCE_A-5_102491 \\
ERCE_B-2_102491
\end{tabular}}} \\
\hline \multirow{2}{*}{\multicolumn{7}{|c|}{\begin{tabular}{|l|} 
ERCE_B-2_102491 \\
ERCE_B-3_102491
\end{tabular}}} \\
\hline & & & & & & \\
\hline \multicolumn{7}{|l|}{ ERCE_B-4_102491 } \\
\hline \multicolumn{7}{|l|}{ EACE_B-5A_102491 } \\
\hline \multicolumn{7}{|l|}{ EACE_B-6_102491 } \\
\hline \multirow{2}{*}{\multicolumn{7}{|c|}{\begin{tabular}{|l|} 
EACE_B-7_102491 \\
EACE_B-8 102491
\end{tabular}}} \\
\hline \multirow{2}{*}{\multicolumn{7}{|c|}{$\frac{\text { EACE_B-8_102491 }}{\text { ERCE_B-9_102491 }}$}} \\
\hline & & & & & & \\
\hline \multicolumn{7}{|l|}{ OE_WETF-1_082092 } \\
\hline \multirow{2}{*}{\multicolumn{7}{|c|}{$\begin{array}{l}\text { OE_WETF-2_082082 } \\
\text { OE WETF-4 } 081992\end{array}$}} \\
\hline \multirow{2}{*}{\multicolumn{7}{|c|}{ OE_WETF-4_081992 }} \\
\hline \multirow{2}{*}{\multicolumn{3}{|c|}{$\frac{\text { OE_WETF-5_082082 }}{\text { OE_WETF-6_082082 }}$}} & & & & \\
\hline & & & & & & \\
\hline \multicolumn{7}{|l|}{ OE_WETF.7_081992 } \\
\hline \multicolumn{7}{|l|}{ OE_WETF-0_082082 } \\
\hline \multicolumn{7}{|l|}{ GA_DA-1_060789 } \\
\hline GA_DA-2_060789 & & & & & & \\
\hline GA_DA-3_060789 & & & & & & \\
\hline QA_DA-4_060789 & & & & & & \\
\hline GA_DA-5_060789 & & & & & & \\
\hline GA_DA-6_060789 & & & & & & \\
\hline GA_DA-7_060789 & & & & & & \\
\hline GA_DA-8_060789 & & & & & & \\
\hline GA_B-1_060789 & & & & & & \\
\hline GA.101_0206B9 & & & & & & \\
\hline GA_102_020689 & & & & & & \\
\hline QA_103_020689 & & & & & & \\
\hline QA_104_020689 & & & & & & \\
\hline GE_B-1_033187 & & & & & & \\
\hline GE_B-2_040187 & & & & & & \\
\hline GE_B-3_040187 & & & & & & \\
\hline GE_B-5_033187 & & & & & & \\
\hline GE_B-6_040187 & & & & & & \\
\hline GE_B-7_040187 & & & & & & \\
\hline GE_B-9_033187 & & & & & & \\
\hline GE_B-10 033187 & & & & & & \\
\hline GE_B-11_040187 & & & & & & \\
\hline GE B-13.033087 & & & & & & \\
\hline GE_B-14_033187 & & & & & & \\
\hline GE_B-17_033087 & & & & & & \\
\hline ERC_CH.5_110289 & & & & & & \\
\hline ERCE_C5-8_092890 & & & & & & \\
\hline
\end{tabular}


Table A4. Soil Boring Point Source Data Fill Characteristics (Continued)

\begin{tabular}{|c|c|c|c|c|c|c|c|}
\hline LOCATIONID & Junconsol & FILLTHK & FILLCONFID & BOILYA1 & DESEYA1 & BOTLYRR & DESLYRE \\
\hline ERCE_C5-9_092890 & 18.00 & 18.00 & 4 & 4.00 & Concrete, crushed stone & 18.00 & Shale tragments \\
\hline ERCE_C5-10_092890 & 29.00 & 29.00 & 4 & 6.00 & Silt with shab Iragments & 17.00 & Silty clay with shale fragments \\
\hline GA_B-1_0318B8 & 8.00 & 8.00 & 5 & 8.00 & Clay with gravel, wood frapments, black organics & & \\
\hline QA_B-2_031888 & 2.00 & 2.00 & 5 & 2.00 & Clay ind weathered shalo with gravel & & \\
\hline GA_B-10_031888 & 6.50 & 6.50 & 5 & 6.50 & Clay with wood/rock/coal/shale tragments & & \\
\hline GA_B-12_031888 & 7.00 & 7.00 & 5 & 7.00 & Silty clay with gravel, wood trapmente & & \\
\hline GA_B-13_0318B8 & 8.00 & 8.00 & 5 & 5.00 & Silty clay with shale fragments & 6.00 & Silty clay with weathered shale, mall roots \\
\hline OE_WSF-1_113092 & 18.00 & 10.00 & 5 & 1.50 & Asphalt, crushed stone & 5.00 & Clay with weathered shale/imestone tragments \\
\hline OE_WSF-2_113092 & 19.00 & 11.00 & 5 & 1.50 & Asphalt, crushed slono & 6.50 & Silty clay with weathered shale/limestone Iragments \\
\hline OE_WSF-3 120192 & 18.00 & 10.00 & 5 & 1.50 & Asphalt, crushed stone & 4.00 & Weathered clayoy shalo \\
\hline OE_WSF-4_120192 & 17.50 & B.50 & 5 & 1.50 & Asphalt, crushed slone & 6.50 & Weathered dayey shale \\
\hline OE_WSF-5_120192 & 19.00 & 11.00 & 5 & 1.50 & Aaphalt, cruahed stone & 4.00 & Woathered clayey shale \\
\hline OE_WSF-6_120392 & 18.70 & 13.00 & 5 & 1.50 & Crushod stono, clay & 2.50 & Cby \\
\hline OE_WSF.7_120292 & 23.00 & 11.50 & 5 & 3.00 & Crushod stone with clay & 10.00 & Silty clay with rock/shale fragments \\
\hline OE_WSF-8_120192 & 19.00 & 13.00 & 5 & 1.50 & Grushed atone with clay, brick tragmente & 7.50 & Silty clay with weathored shale \\
\hline OE WSF-9_120292 & 23.00 & 14.00 & 5 & 2.50 & Crushed sione, clay & 7.00 & Silty clay with rock fragments, woathered shale, crushod stone \\
\hline OE_WSF-10_120392 & 24.50 & 15.00 & 5 & 2.50 & Silty clay, crushed stone, wire pieces & 5.00 & Crushed stone with clay \\
\hline OE_WSF-11_120392 & 23.00 & 11.50 & 5 & 2.50 & Silty clay, crushed slone & 5.00 & Weathered shale, clay, crushed sione \\
\hline OE WSF-12_120292 & 18.50 & 15.00 & 5 & 2.50 & Silty clay, cruahod stone, coal, woathered shale & 5.00 & Crughed stone, clay, brick irapments \\
\hline OE_WSF-13_120292 & 18.00 & 13.50 & 5 & 5.00 & Gruahed atone, clay, woathered shele & 13.50 & Silty clay with weathered shale tragments \\
\hline OE_1-A_010993 & 26.50 & 13.00 & 5 & 0.40 & Concreve & 3.00 & Cruahed stone \\
\hline OE_2.A_011093 & 19.20 & 16.50 & 5 & 0.50 & Concrete & 6.10 & Crushed stone \\
\hline OE_3-A_011093 & 11.60 & 10.00 & 5 & 0.50 & Concreto & 1.00 & NOSSMPLE \\
\hline OE_6-A_011093 & 25.50 & 7.00 & 5 & 0.50 & Concrete & 1.50 & Cruahed stone \\
\hline $0 E_{-} 7-A_{-} 011093$ & 26.20 & 8.50 & s. & 0.50 & Concrete & 2.00 & Crushed stone \\
\hline S8ME_B-15_091587 & 18.50 & 5.00 & 4 & 0.20 & Grase, roots, topsoll & 5.00 & Possible fill of sandy clayey silt or highly weathered shale \\
\hline S8ME_B-17_091487 & 17.50 & 6.00 & 3 & 1.00 & Concrole, gravol & 6.00 & Possible fill of sandy clayey sitt \\
\hline S8ME_B-22_090287 & 24.00 & 12.00 & 4 & 1.00 & Asphaltic concrote, gravel base & 7.00 & Clayey sill with shale/limestone fragments \\
\hline S8ME_B-23A_0902B7 & 29.50 & 12.50 & 5 & 1.00 & Asphallic concrete, gravel base & 12.50 & Sandy clayey ollt with shale/limestone tragments \\
\hline SEME_B-24_090187 & 28.50 & 12.00 & 5 & 1.00 & Asphaltic concrete, gravel base & 12.00 & Sandy clayey silf with shalo tragments \\
\hline S\&ME_B-25A_090187 & 15.00 & 15.00 & 5 & 1.00 & Asphaltic concrete, gravel base & 15.00 & Sandy clayey silt \\
\hline S\&ME_B-26_090187 & 15.00 & 5.00 & 5 & 1.00 & Asphaltic concrete, pravel base & 5.00 & Sandy clayey sin with chale fragmenls \\
\hline S\&ME_B.27A_083187 & 25.00 & 6.00 & 4 & 1.00 & Asphaltic concrete, gravel base & 6.00 & Possible sandy clayey silf fill \\
\hline GE_B-3_121886 & 11.10 & 6.50 & 4 & 0.50 & Gravel & 6.50 & Clay with silt, weathered shalo, limestone gravel \\
\hline GE_TB-2_112984 & 20.25 & 18.00 & 3 & 4.75 & Topeoil, clayey silt with wealhered shate & 7.75 & Clayey sill with chort \\
\hline GE_TB-3_120784 & 16.25 & 15.00 & 3 & 0.50 & Asphaltic concrele, limestone gravel & 4.75 & Clayey all with weathored shalo \\
\hline GE_TB-9_113084 & 4.00 & 4.00 & 3 & 0.60 & Topsoll & 4.00 & Clayoy silt wilh woathered shale, organic material \\
\hline GA_B-1_112487 & 12.00 & 12.00 & a) & 8.50 & Topsoil, silty clay with rock Iragments, some organics & 12.00 & Silty clay, weathered shale \\
\hline EACE_ESF-11_082991 & 27.10 & 5.00 & 5 & 5.00 & Silty clay with rock fragments, rools & & \\
\hline ERCE_ESF.15_082991 & 24.20 & 5.00 & 4) & 5.00 & Possible fill of silly clay w/chert frags, black specks & & \\
\hline EACE_ESF-16_082991 & 35.50 & 5.00 & 5 & 5.00 & Silly clay with crushed slone, chert lragmenls & & \\
\hline GE_B-2_051486 & 10.90 & 10.00 & 5 & 1.00 & Concrele, gravol & 5.00 & Silt with clay \\
\hline GE_B-3_051486 & 12.50 & 9.00 & 5 & 1.00 & Concrele, gravel & 5.00 & Clay with sill and shale \\
\hline GA_CN-1_021589 & 21.20 & 2.00 & 5 & 2.00 & Topsoil, clayey sill with rock tragments & & \\
\hline GA_CN-2_021589 & 19.00 & 2.00 & 5 & 2.00 & Topsoll, clayey silt with rock fregments & & \\
\hline GA_CN-3_021589 & 21.70 & 2.00 & 5 & 2.00 & Topsoll, clayey silt with rock tragmente & & \\
\hline GA_CN-4_021589 & 17.20 & 5.00 & 5 & 5.00 & Topsoll, clayey silt with rock fragmente & & \\
\hline GA_CN-5_021589 & 22.30 & 2.00 & 5 & 2.00 & Topsoil, clayey silt with rock fragments & & \\
\hline GA_CN-6_021589 & 16.30 & 7.00 & 5 & 7.00 & Topsoli, clayey sith with shaie fragments & & \\
\hline GA_CN-7_021589 & 18.10 & 2.00 & 5 & 2.00 & Topsoll, silty clay with rock Iragments & & \\
\hline
\end{tabular}


Table A4. Soil Boring Point Source Data Fill Characteristics (Continued)

\begin{tabular}{|c|c|c|c|c|}
\hline LOCATIONID & BOTLYRO & DESLYRS & BOTLYRA & DESLYAM \\
\hline \multicolumn{5}{|l|}{ EACE_C5-9_092890 } \\
\hline ERCE_C5-10_092890 & 26.00 & Shale tragments & 29.00 & Silt with shale fragmente \\
\hline \multicolumn{5}{|l|}{ GA_B-1_031880 } \\
\hline \multicolumn{5}{|l|}{ GA_B-2_031888 } \\
\hline \multicolumn{5}{|l|}{ GA_B-10_031888 } \\
\hline \multicolumn{5}{|l|}{ GA_B.12_031888 } \\
\hline QA_B-13_031888 & 8.00 & Rock fragments grading lo weathered shale Iregments & & \\
\hline OE_WSF-1_113092 & 10.00 & Clayey weathered shaie & & \\
\hline OE_WSF-2_113092 & 8.00 & Weathered shale & 11.00 & Silty clay with rock tragments \\
\hline OE_WSF.3_120192 & 10.00 & Sitty clay with weathered shale trapments & & \\
\hline OE_WSF.4_120192 & 8.50 & Silty clay with rock fragments & & \\
\hline OE_WSF-5_120192 & 6.50 & Silty clay with weathered shalo fragments & 9.00 & Weathered clayey shalo \\
\hline OE_WSF-6_120392 & 5.00 & Woathered clayey shale with limeatione fragmenls & 10.00 & Weathered clayoy shale \\
\hline OE_WSF.7_120292 & 11.50 & Weathered clayey shale with roots & & \\
\hline OE_WSF-8_120192 & 10.00 & Woathered clayey shate & 13.00 & Silly clay with rools \\
\hline OE_WSF-9_120292 & 10.00 & Weathored clayey ahale & 14.00 & Silty clay with weathered shalo tragments \\
\hline OE_WSF-10_120392 & 7.00 & NOSAMPLE & 15.00 & Silty clay with weathered shalo tragments \\
\hline OE_WSF-11_120392 & 7.50 & Clay with crushed stone, weathered shale & 11.50 & Silty clay with weathered shale \\
\hline OE_WSF-12_120292 & 10.00 & Suly clay, wealthered shale, crushod stone, wire ploce & 15.00 & Silly clay with woathored thalo \\
\hline \multicolumn{5}{|l|}{ OE_WSF-13_120292 } \\
\hline OE_1-A_010993 & 5.50 & Crushed stone, clay & 10.50 & Clayey silt, shale frapments, rock tragments \\
\hline OE_2-A_011093 & 8.50 & Cleyey all with wire, rock fraoments & 9.10 & Rock Irapments \\
\hline OE_3-A_011093 & 3.50 & Crushed stone & 5.00 & Glayey all with shale \\
\hline OE_6-A_011093 & 3.00 & Woathered shalo, clayey silt & 5.00 & Clayoy silt \\
\hline$O E_{-7-A} \quad 011093$ & 3.50 & Decomposed shate & 4.50 & Weathered shale, silty clay \\
\hline \multicolumn{5}{|l|}{ S\&ME_B-15_091587 } \\
\hline \multicolumn{5}{|l|}{ S\&ME_B-17_091487 } \\
\hline S8ME_B-22_090287 & 12.00 & Probable fill of sandy clayey ailf & & \\
\hline \multicolumn{5}{|l|}{ S\&ME_B-23A_090287 } \\
\hline \multicolumn{5}{|l|}{ S\&ME_B-24_090187 } \\
\hline \multicolumn{5}{|l|}{ S8ME_B-25A_090187 } \\
\hline \multicolumn{5}{|l|}{ S8ME_B-26_090187 } \\
\hline \multicolumn{5}{|l|}{ SEME_B-27A_063187 } \\
\hline \multicolumn{5}{|l|}{ GE $8-3,121886$} \\
\hline GE_TB-2_112984 & 10.00 & Silty clay with organic material & 18.00 & Clayey ailt with woathered shalo, organic material \\
\hline GE_TB-3_120784 & 10.00 & Clayey sill with weathered shale & 15.00 & Silty clay with weathered shate, organic material \\
\hline \multicolumn{5}{|l|}{ GE_TB-9_113084 } \\
\hline \multicolumn{5}{|l|}{ GA_B-1_112487 } \\
\hline \multicolumn{5}{|l|}{ ERCE_ESF-11_082991 } \\
\hline \multicolumn{5}{|l|}{ ERCE_ESF-15_082991 } \\
\hline \multicolumn{5}{|l|}{ EACE_ESF-16_082991 } \\
\hline GE_B-2_051486 & 8.00 & Clay with sill and chert & 10.00 & Clay with silt, wood, weathered shale \\
\hline GE $8-3,051486$ & 7.50 & Clay with silt & 9.00 & Clay with silt, organic material \\
\hline \multicolumn{5}{|l|}{ GA_CN-1_021589 } \\
\hline \multicolumn{5}{|l|}{ GA_CN-2_021589 } \\
\hline GACN-3.021589 & & & & \\
\hline GA_CN-4_021589 & & & & \\
\hline GA_CN-5 021589 & & & & \\
\hline GA_CN-6_021589 & & & & \\
\hline GA_CN-7 021589 & & & & \\
\hline
\end{tabular}


Table A4. Soil Boring Point Source Data Fill Characteristics (Continued)

\begin{tabular}{|c|c|c|c|c|}
\hline LOCATIONID & BOTLYAS & DESLYA5 & BOTLYA6 & DESLYPB \\
\hline \multicolumn{5}{|l|}{ ERCE_C5-9_092890 } \\
\hline \multicolumn{5}{|c|}{ ERCE_C5-10_092890 } \\
\hline \multirow{2}{*}{\multicolumn{5}{|c|}{ GA_B-1_0318B8 }} \\
\hline & \multicolumn{4}{|c|}{ GA_B-2_0318BB } \\
\hline \multicolumn{5}{|l|}{ GA_B-10_0318B8 } \\
\hline \multirow{2}{*}{\multicolumn{5}{|c|}{ GA_B-12_031888 }} \\
\hline \multicolumn{2}{|l|}{ GA_B-13_03188B } & & & \\
\hline \multicolumn{5}{|l|}{ OE_WSF-1_113092 } \\
\hline \multicolumn{5}{|l|}{ OE_WSF-2_113092 } \\
\hline \multicolumn{5}{|l|}{ OE_WSF-3_120192 } \\
\hline \multicolumn{5}{|l|}{ OE_WSF-4_120192 } \\
\hline OE_WSF-5_120192 & 11.00 & Silty clay with rock and weathered shale tragments & & \\
\hline OE_WSF-6_120392 & 13.00 & Silty clay with weathered shale and rock fragmente & & \\
\hline \multicolumn{5}{|l|}{ OE_WSF.7_120292 } \\
\hline \multicolumn{5}{|l|}{ OE_WSF-8__120192 } \\
\hline \multicolumn{5}{|l|}{ OE_WSF-9_120292 } \\
\hline \multicolumn{5}{|c|}{ OE_WSF-10_120392 } \\
\hline \multicolumn{5}{|l|}{ OE_WSF-11_120392 } \\
\hline \multicolumn{5}{|c|}{ OE_WSF-12_120292 } \\
\hline \multicolumn{5}{|c|}{ OE_WSF-13_120292 } \\
\hline$\overline{O E}_{-} 1-A_{-} 010993$ & 12.50 & Silty clay with rock/shale Iragments, roots & 13.00 & Clayey silt, topsoil $013-14$ \\
\hline OE_2-A_011093 & 10.00 & Sandy silt & 15.50 & Silly clay with rock/brick fregments, wood \\
\hline OE_3-A_011093 & 8.50 & Sandy silty clay with shale tragments & 10.00 & Clayey silt, weathered shale tragments \\
\hline OE_6-A_011093 & 7.00 & Silty clay with rock tragments & & \\
\hline OE_7-A_011093 & 5.50 & Clay with weathered shalo fragments & 8.50 & Silly clay with shale frapments \\
\hline \multicolumn{5}{|l|}{ S\&ME_B-15_091587 } \\
\hline \multicolumn{5}{|l|}{ S\&ME_B-17_091487 } \\
\hline \multicolumn{5}{|l|}{ S\&ME_B-22_090287 } \\
\hline SBME_B.23A_0902 & & & & \\
\hline SEME_B-24_09018 & & & & \\
\hline SAME_B-25A_0901 & & & & \\
\hline S\&ME_B-26_09018 & & & & \\
\hline S8ME_B-27A_083 & & & & \\
\hline GE_B-3_121886 & & & & \\
\hline GE_TB-2_112984 & & & & \\
\hline GE_TB-3_120784 & & & & \\
\hline GE_TB-9_113084 & & & & \\
\hline GA_B-1_112487 & & & & \\
\hline EACE_ESF-11_082 & & & & \\
\hline ERCE_ESF-15_082 & & & & \\
\hline EACE_ESF-16_082 & & & & \\
\hline GE_B-2_051486 & & & & \\
\hline GE_B-3_051486 & & & & \\
\hline GA_CN-1_021589 & & & & \\
\hline GA_CN-2_021589 & & & & \\
\hline GA_CN-3_021589 & & & & \\
\hline GA_CN-4_021589 & & & & \\
\hline GA_CN-5_021589 & & & & \\
\hline GA_CN-6_021589 & & & & \\
\hline GA_CN-7_021589 & & & & \\
\hline
\end{tabular}




\section{Table A4. Soil Boring Point Source Data Fill Characteristics (Continued)}

\begin{tabular}{|c|c|c|c|c|c|c|}
\hline LOCATIONID & BOTLYR7 & DESLYA7 & TBOTLYPA & DESLYPP & BOTLYA9 & DESLYA9 \\
\hline \multicolumn{7}{|l|}{ ERCE_C5-9_092890 } \\
\hline \multicolumn{7}{|c|}{ ERCE_C5-10_092890 } \\
\hline \multirow{2}{*}{\multicolumn{7}{|c|}{\begin{tabular}{|l|} 
GA_B-1_031888 \\
$G A \_B-2 \_031888$
\end{tabular}}} \\
\hline & & & & & & \\
\hline \multicolumn{7}{|l|}{ GA_B-10_031888 } \\
\hline \multicolumn{7}{|l|}{ GA_B-12_031888 } \\
\hline \multirow{2}{*}{\multicolumn{7}{|c|}{ GA_B-13_031888 }} \\
\hline \multicolumn{3}{|l|}{ OE_WSF-1_113092 } & & & & \\
\hline \multicolumn{7}{|l|}{ OE_WSF-2_113092 } \\
\hline \multirow{2}{*}{\multicolumn{7}{|c|}{$\frac{\text { OE_WSF-3_120192 }}{\text { OE_WSF-4 120192 }}$}} \\
\hline \multirow{2}{*}{\multicolumn{7}{|c|}{$\frac{\text { OE_WSF-4_120192 }}{\text { OE_WSF-5_120192 }}$}} \\
\hline & & & & & & \\
\hline \multicolumn{7}{|l|}{ OE_WSF-6_120392 } \\
\hline \multicolumn{7}{|l|}{ OE_WSF.7_120292 } \\
\hline \multicolumn{7}{|l|}{ OE_WSF-8_120192 } \\
\hline \multicolumn{7}{|l|}{ OE_WSF.9_120292 } \\
\hline \multirow{2}{*}{\multicolumn{7}{|c|}{ OE_WSF-10_120392 }} \\
\hline \multirow{2}{*}{\multicolumn{7}{|c|}{ OE_WSF-11_120392 }} \\
\hline \multicolumn{2}{|c|}{ OE_WSF-12_120292 } & & & & & \\
\hline \multirow{2}{*}{\multicolumn{7}{|c|}{ OE_WSF-13_12029? }} \\
\hline & & & & & & \\
\hline$\overline{O E_{-} 2-A_{-} 011093}$ & 16.50 & Silly clay with rock fragmenis & & & & \\
\hline \multicolumn{7}{|l|}{ OE_3.A_011093 } \\
\hline OE_6-A_011093 & & & & & & \\
\hline OE_7.A_011093 & & & & & & \\
\hline S\&ME_B-15_0915t & & & & & & \\
\hline S8ME_B-17_0914 & & & & & & \\
\hline S\&ME_B-22_0002 & & & & & & \\
\hline S\&ME_B-23A_090 & & & & & & \\
\hline S\&ME_B-24_09011 & & & & & & \\
\hline S8ME_8-25A_090 & & & & & & \\
\hline S8ME_B-26_09011 & & & & & & \\
\hline S\&ME_B-27A_083 & & & & & & \\
\hline GE_B-3_121886 & & & & & & \\
\hline GE_TB-2_112984 & & & & & & \\
\hline GE_TB-3_120784 & & & & & & \\
\hline GE_TB-9_113084 & & & & & & \\
\hline GA_B-1_112487 & & & & & & \\
\hline ERCE_ESF-11_082 & & & & & & \\
\hline ERCE_ESF-15_082 & & & & & & \\
\hline ERCE_ESF-16_082 & & & & & & \\
\hline GE_B-2_051486 & & & & & & \\
\hline GE_B-3_051486 & & & & & & \\
\hline GA_CN-1_021589 & & & & & & \\
\hline GA_CN-2_021589 & & & & & & \\
\hline GA_CN-3_021589 & & & & & & \\
\hline GA_CN-4_021589 & & & & & & \\
\hline GA_CN.5 021589 & & & & & & \\
\hline GA_CN-6_021589 & & & & & & \\
\hline GA_CN-7_021589 & & & & & & \\
\hline
\end{tabular}


Table A4. Soil Boring Point Source Data Fill Characteristics (Continued)

\begin{tabular}{|c|c|c|c|c|c|c|c|}
\hline LOCATIONID & IUNCONsa & FILLTHK & FLLCONFID & BOTYR1 & DESLYA1 & TBOTLYR & DESLYRE \\
\hline GA_CN-8_021589 & 17.80 & 2.00 & 5 & 2.00 & Topsoil, clayey silt with rock frogments & & \\
\hline GA_CN-10_021589 & 14.60 & 2.00 & 5 & 2.00 & Topsoll, clayey silt with rock fregmenta & & \\
\hline GA_CN-11_021589 & 13.70 & 1.50 & 5 & 1.50 & Topsoil, clayey silt with rock fragments & & \\
\hline GA_CN-17_021589 & 24.50 & 6.50 & 5 & 6.50 & Topsoil, clayoy sith with rock fragments & & \\
\hline GA_CN-18_021589 & 24.70 & 1.00 & 5 & 1.00 & Topsoll, clayoy all with rock tragments & & \\
\hline GA_CN-19_021589 & 24.80 & 1.50 & 5 & 1.50 & Topsoll, silty clay with shalo fragments & & \\
\hline S\&ME_WC-2-B_042689 & 28.00 & 28.00 & 4 & 2.50 & Gravel & 7.50 & Clay with shale Iragments \\
\hline SQME_WC-3-B_050389 & 35.00 & 30.00 & 4 & 0.70 & Gravel & 8.00 & Clay with shaib fragmente, and \\
\hline SBME_WC-5_042689 & 30.00 & 27.00 & 4 & 0.60 & Gravel & 12.00 & Clay with shale Iragments \\
\hline S\&ME,WC-6_042589 & 31.00 & 31.00 & 4 & 0.50 & Gravel & 31.00 & Fill to possible alluvial silty clay with rock Iragments \\
\hline S\&ME_FH-1_030889 & 3.00 & 3.00 & 5 & 0.50 & Concrete & 3.00 & Shale/limestone tragments \\
\hline ERCE_IP-1_091990 & 53.01 & 6.00 & 3 & 6.00 & Silt with rock tragments & & \\
\hline EACE IP.5_091990 & 27.35 & 5.00 & 3 & 5.00 & Silt with shaldrock tragments & & \\
\hline ERCE_IP-11_091990 & 60.05 & 7.50 & 3 & 7.50 & Sill with chert Iragmente & & \\
\hline
\end{tabular}


Table A4. Soil Boring Point Source Data Fill Characteristics (Continued)

\begin{tabular}{|c|c|c|c|c|}
\hline LOCATIONID & BOTYYA & DESLYPB & BOTLYA4 & DESLYRA \\
\hline \multicolumn{5}{|l|}{ GA_CN-8_021589 } \\
\hline \multicolumn{5}{|l|}{ QA_CN-10_021589 } \\
\hline \multicolumn{5}{|l|}{ GA_CN-11_021589 } \\
\hline \multirow{2}{*}{\multicolumn{5}{|c|}{ GA_CN-17_021589 }} \\
\hline & & & & \\
\hline \multicolumn{5}{|l|}{ GA_CN-19_021589 } \\
\hline SSME_WC-2-B_042689 & 10.00 & Silty clay with rock fragments & 18.00 & Clayey sand with shale tragments \\
\hline S\&ME_WC-3-B_050389 & 12.50 & Sandy clay with shale fragments & 18.00 & Clayey end with thale fragrments \\
\hline S\&ME_WC-5_042689 & 27.00 & Fill to possible allimial sandy clay with rock fragmente & & \\
\hline \multirow{2}{*}{\multicolumn{5}{|c|}{$\frac{\text { SEME_WC-6_042589 }}{\text { S\&ME_FH-1 } 030889}$}} \\
\hline & & & & \\
\hline \multicolumn{5}{|l|}{ ERCE_IP.1_091990 } \\
\hline \multicolumn{5}{|l|}{ ERCE_IP.5_091890 } \\
\hline EACE_IP.11_091990 & & & & \\
\hline
\end{tabular}


Table A4. Soil Boring Point Source Data Fill Characteristics (Continued)

\begin{tabular}{|c|c|c|c|c|}
\hline LOCATIONID & BOTLYR5 & DESLYRS & BOTLYA6 & DESLYP6 \\
\hline \multicolumn{5}{|l|}{ GA_CN-8_0215B9 } \\
\hline \multirow{2}{*}{\multicolumn{5}{|c|}{$\overline{G A}=\overline{C N}-10 \_021589$}} \\
\hline GA_CN-11_0215B8 & & & & \\
\hline \multicolumn{5}{|l|}{ GA_CN-17_021589 } \\
\hline \multicolumn{5}{|l|}{ QA_CN-18_021589 } \\
\hline \multicolumn{5}{|l|}{ GA_CN-19_021589 } \\
\hline SAME_WC-2-B_042689 & 20.00 & Sndy clay with rock Iragments, woody orpanics & 28.00 & Fill or alluvial silly clay w/shale tragmente \\
\hline S8ME_WC-3-B_050389 & 20.00 & Fill or alluvial sandy clay with rock Iragmente & 30.00 & Fill or alluviol silty clay \\
\hline \multicolumn{5}{|l|}{ SAME_WC-5_042689 } \\
\hline \multicolumn{5}{|l|}{ SQME_WC-6_042589 } \\
\hline \multirow{2}{*}{\multicolumn{5}{|c|}{ S\&ME_FH-1_030889 }} \\
\hline & & & & EACE_IP-1_091990 \\
\hline EACE_IP.5_091990 & & & & \\
\hline ERCE_IP.11_091990 & & & & \\
\hline
\end{tabular}


Table A4. Soil Boring Point Source Data Fill Characteristics (Continued)

\begin{tabular}{|c|c|c|c|c|c|c|}
\hline LOCATIONID & BOTLYA7 & DESLYA7 & BOIYYPB & DESLYPB & BOTYYAO & DESLYA9 \\
\hline \multicolumn{7}{|l|}{ GA_CN-B_021589 } \\
\hline \multicolumn{7}{|l|}{ GA_CN-10_021589 } \\
\hline \multirow{2}{*}{\multicolumn{7}{|c|}{$\begin{array}{l}\mathrm{GA} C \mathrm{CN}-11=021589 \\
\mathrm{GA} C \mathrm{CN}-17=021589\end{array}$}} \\
\hline \multirow{2}{*}{\multicolumn{7}{|c|}{\begin{tabular}{|l|}
$A A-C N-17=021589$ \\
$A A-C N-18+021589$
\end{tabular}}} \\
\hline & & & & & & \\
\hline \multicolumn{7}{|l|}{ GA_CN-19_021589 } \\
\hline \multicolumn{7}{|l|}{ SSME_WC-2-B_042689 } \\
\hline \multicolumn{7}{|c|}{ SQME_WC-3-B_050389 } \\
\hline \multicolumn{7}{|l|}{ S\&ME_WC-5_042689 } \\
\hline \multirow{2}{*}{\multicolumn{7}{|c|}{$\begin{array}{l}\text { SaME_WC-6_042589 } \\
\text { S8ME_FH-1 030889 }\end{array}$}} \\
\hline S\&ME_FH-1_030889 & & & & & & \\
\hline \multicolumn{7}{|l|}{ ERCE_IP-1_091890 } \\
\hline ERCE_IP-5 091990 & & & & & & \\
\hline EACE_IP.11_091890 & & & & & & \\
\hline
\end{tabular}




\section{DATA SOURCES}

Bechtel 1984. Geologic Data on Twenty Monitoring Wells Installed in Bear Creek Valley In September and October, 1984, Y/SUB/84B-47974C/12, Bechtel National Corp., for Martin Marietta Energy Systems, Inc., Oak Ridge Y-12 Plant.

Eaton, J. M. and Van Ryn, F.R. 1991. Site Investigation Report for Underground Storage Tanks 1219-U, 1222-U, 2068-U, and 2082-U at the Rust Garage Facility, Oak Ridge Y-12 Plant, Oak Ridge, Tennessee, Y/SUB/91B-TJ997C/3, Martin Marietta Energy Systems, Inc., Oak Ridge Y-12 Plant.

Earth Technology Corporation. 1991. RCRA Facility Investigation for the Group 2 Sites at Oak Ridge Y-12 Plant, Tennessee, Site Characterization Summary (Draft Report), Contract No. 22B-99785C, for Martin Marietta Energy Systems, Inc., Oak Ridge Y-12 Plant.

EDGe 1989. 1988 Monitor-Well Installations at the Oak Ridge Y-12 Plant, Oak Ridge, Tennessee, Y/SUB/89B-99005V/2, EDGe Group, Inc., for Martin Marietta Energy Systems, Inc., Oak Ridge Y-12 Plant.

ERC 1990. Geotechnical Study for the Proposed FCAP Changehouse 7-A, Y-12 Plant, Oak Ridge, Tennessee, ERC/EDGe File No. C129, MMES Purchase Order No. EB-332, ERC/EDGe, Inc., for Martin Marietta Energy Systems, Inc., Oak Ridge Y-12 Plant.

ERCE 1990a. Proposed Visitor Control Center, Y-12 Plant, Oak Ridge, Tennessee, ERCE File No. 90-J408, MMES Purchase Order No. EB-363, ERCE, Inc., for Martin Marietta Energy Systems, Inc., Oak Ridge Y-12 Plant.

ERCE 1990b. Proposed FCAP 89 Changehouse 5-A, Y-12 Plant, Oak Ridge, Tennessee, ERCE File No. J392, MMES Purchase Order No. EB-353, ERCE, Inc., for Martin Marietta Energy Systems, Inc., Oak Ridge Y-12 Plant.

ERCE 1990c. Proposed Isostatic Press Building, Y-12 Plant, Oak Ridge, Tennessee, ERCE File No. J393, MMES Purchase Order No. EB-355, ERCE, Inc., for Martin Marietta Energy Systems, Inc., Oak Ridge Y-12 Plant.

ERCE 1990d. Proposed Plant Support Office Building, Y-12 Plant, Oak Ridge, Tennessee, ERCE File No. 90-J394, MMES Purchase Order No. EB-352, ERCE, Inc., for Martin Marietta Energy Systems, Inc., Oak Ridge Y-12 Plant.

ERCE 1991a. Interim Geotechnical Study for the Proposed Environmental Support Facility, Site \#2, Y-12 Plant, Oak Ridge, Tennessee, MMES Purchase Order No. 88B-99977V, Rel. C-11, ERCE, Inc., for Martin Marietta Energy Systems, Inc., Oak Ridge Y-12 Plant.

ERCE 1991b. Geotechnical Study for the Proposed Fueling Station Relocation at the Y-12 Plant, Oak Ridge, Tennessee, ERCE File No. C290, ERCE, Inc., for Martin Marietta Energy Systems, Inc., Oak Ridge Y-12 Plant. 
ERCE 1991c. Calendar Years 1989 and 1990 Monitoring Well Installation Program, Y-12 Plant, Oak Ridge, Tennessee, Y/TS-760, ERCE, Inc., for Martin Marietta Energy Systems, Inc., Oak Ridge Y-12 Plant.

GA 1988a. Geotechnical Study for the Proposed Environmental Support Facility, Y-12 Plant, Oak Ridge, Tennessee, GA File No. 87-0618K, MMES Purchase Order No. EB-274, Geological Associates Division, EDGe Group, Inc., for Martin Marietta Energy Systems, Inc., Oak Ridge Y-12 Plant.

GA 1988b. Proposed FCAP Building, North First Street at "H" Road, Y-12 Plant, Oak Ridge, Tennessee, GA File No. 87-0369K, MMES Purchase Order No. EB-264, Geological Associates Division, EDGe Group, Inc., for Martin Marietta Energy Systems, Inc., Oak Ridge Y-12 Plant.

GA 1988c. Changehouse and Medical Staging Depot, Y-12 Plant, Oak Ridge, Tennessee, GA File No. 88-X654, MMES Purchase Order No. EB-275, Geological Associates Division, EDGe Group, Inc., for Martin Marietta Energy Systems, Inc., Oak Ridge Y-12 Plant.

GA 1989a. Slope Study for the Proposed Changehouse 12-A, Y-12 Plant, Oak Ridge, Tennessee, EDGE File No. 88-X683, MMES Purchase Order No. EB-288, Geological Associates Division, EDGe Group, Inc., for Martin Marietta Energy Systems, Inc., Oak Ridge Y-12 Plant.

GA 1989b. Proposed OROICN Buildings at the Y-12 and K-25 Plants, MMES, Inc., GA File No. 88-X896, MMES Purchase Order No. EB-305, Geological Associates Division, EDGe Group, Inc., for Martin Marietta Energy Systems, Inc., Oak Ridge Y-12 Plant.

GA 1989c. Supplemental Geotechnical Study for the Proposed Environmental Support Facility, Y-12 Plant, Oak Ridge, Tennessee, ERCE File No. B429 and 87-0618K, MMES Purchase Order No. EB-317, Geological Associates Division, EDGe Group, Inc., for Martin Marietta Energy Systems, Inc., Oak Ridge Y-12 Plant.

GEOTEK 1985. Geotechnical Investigation for the Proposed Addition to the South Side of Building 9103, Y-12 Plant, Oak Ridge, Tennessee, Geotek Project No. 83-1370, MMES Purchase Order No. 86B-47970V Rel. Y-26, Geotek Engineering, Inc., for Martin Marietta Energy Systems, Inc., Oak Ridge Y-12 Plant.

GEOTEK 1986. Geotechnical Investigation for the Proposed Truck Scale, Y-12 Plant, Oak Ridge, Tennessee, Geotek Project No. 83-1370, MMES Purchase Order No. 86B-47970V Rel. Y-89, Geotek Engineering, Inc., for Martin Marietta Energy Systems, Inc., Oak Ridge Y-12 Plant.

GEOTEK 1987a. Geotechnical Investigation for the Proposed Sodium Hypochlorite Station, Y-12 Plant, Oak Ridge, Tennessee, MMES Purchase Order No. 86B-47970V Rel. J-33, Geotek Engineering, Inc., for Martin Marietta Energy Systems, Inc., Oak Ridge Y-12 Plant. 
GEOTEK 1987b. Geotechnical Investigation for the Proposed New Containment Pond for Closure of New Hope Pond, Y-12 Plant, Oak Ridge, Tennessee, Geotek Project No. 83-1370, MMES Purchase Order No. 86B-47970V Rel. J-45, Geotek Engineering, Inc., for Martin Marietta Energy Systems, Inc., Oak Ridge Y-12 Plant.

Geraghty and Miller 1987. Installation of Monitor Wells at the Salvage Yard and Burial Grounds Area of the Y-12 Plant, Y/SUB/86B-00206C/3, Geraghty and Miller, Inc., for Martin Marietta Energy Systems, Inc., Oak Ridge Y-12 Plant.

Geraghty and Miller 1988. Monitor Well Documentation Report for the 1987 Drilling Program at the Y-12 Plant, Y/SUB/87B-00206C/20, Geraghty and Miller, Inc., for Martin Marietta Energy Systems, Inc., Oak Ridge Y-12 Plant.

IT Corporation 1986. Geohydrological Investigation of the Diesel Spill at the Y-12 Plant Service Station, IT Corporation Contract No. 408927.01, for Martin Marietta Energy Systems, Inc., Oak Ridge Y-12 Plant.

OGDEN 1992a. Interim Geotechnical Study for the Proposed Molecular Genetics Laboratory Expansion, Y-12 Plant, Oak Ridge,Tennessee, MMES Purchase Order No. 88B-99977V, Rel. C-23, Ogden Environmental and Energy Services, Inc., for Martin Marietta Energy Systems, Inc., Oak Ridge Y-12 Plant.

OGDEN 1992b. FCAP 1991 Renovate Power Supply System Upgrade Project, Y-12 Plant, Oak Ridge, Tennessee, Ogden File No. 0-4267-0041, Ogden Environmental and Energy Services, Inc., for Martin Marietta Energy Systems, Inc., Oak Ridge Y-12 Plant.

OGDEN 1992c. WETF Head End Modifications, Y-12 Plant, Oak Ridge, Tennessee, Ogden File No. 0-4267-0045, MMES Purchase Order No. 88B-99977V, Rel. C-42, Ogden Environmental and Energy Services, Inc., for Martin Marietta Energy Systems, Inc., Oak Ridge Y-12 Plant.

OGDEN 1992d. Geotechnical Study for the Proposed East End Sanitary Sewer Monitoring Station, Y-12 Plant, Oak Ridge, Tennessee, Ogden File No. 0-4267-0054, MMES Purchase Order No. 88B-99977V, Rel. C-51, Ogden Environmental and Energy Services, Inc., for Martin Marietta Energy Systems, Inc., Oak Ridge Y-12 Plant.

OGDEN 1993a. Geotechnical Study for the Proposed Classified Waste Storage Facility 9720-59 and 9720-32, Y-12 Plant, Oak Ridge, Tennessee, Ogden File No. 0-4267-0053/0057, MMES Purchase Order No. 88B-99977V Rel. C-50/002, Ogden Environmental and Energy Services, Inc., for Martin Marietta Energy Systems, Inc., Oak Ridge Y-12 Plant.

OGDEN 1993b. Subsurface Investigation and Environmental Sampling Ammonium Nitrate Study, Y-12 Plant, Oak Ridge, Tennessee, Ogden File No. 0-4267-0074, MMES Purchase Order No. 88B-99977, Rel. C-70, Ogden Environmental and Energy Services, Inc., for Martin Marietta Energy Systems, Inc., Oak Ridge Y-12 Plant. 
Rothschild, E. R., Turner, R. R., Stow, S. H., Bogle, M. A., Hyder, L. K., Sealand, O. M., and Wyrick, H. J. 1984. Investigation of Subsurface Mercury at the Oak Ridge Y-12 Plant, ORNL/TM-9092, Martin Marietta

Energy Systems, Inc., Oak Ridge National Laboratory.

S\&ME 1987. Report of Subsurface Investigation for the Proposed Central Services Facility, Y-12 Plant, Oak Ridge, Tennessee, S\&ME Job No. 1401-87-108-A, Soil and Material Engineers, Inc., for Martin Marietta Energy Systems, Inc., Oak Ridge Y-12 Plant.

S\&ME 1989a. Report of Subsurface Investigation for the Fire Protection Upgrade, Y-12 Fire Hall Improvement, Y-12 Plant, Oak Ridge, Tennessee, S\&ME Job No. 1401-89-049-A, Soil and Material Engineers, Inc., for Martin Marietta Energy Systems, Inc., Oak Ridge Y-12 Plant.

S\&ME 1989b. Report of Subsurface Investigation for the Waste Coolant Centralized Collection Facility at Y-12, Oak Ridge, Tennessee, S\&ME Job

No. 1401-89-048-A, Soil and Material Engineers, Inc., for Martin Marietta Energy Systems, Inc., Oak Ridge Y-12 Plant.

SAIC 1992. Fiscal Year 1992 Monitoring Well Installation Program, Y-12 Plant, Oak Ridge, Tennessee, Y/SUB/92-99928c(Y11)/2, Science Applications International Corporation for Martin Marietta Energy Systems, Inc., Oak Ridge Y-12 Plant.

SAIC 1993. Fiscal Year 1993 Monitoring Well Installation Program, Y-12 Plant, Oak Ridge, Tennessee, Y/SUB/93-99928c(Y22)/1, Science Applications International Corporation for Martin Marietta Energy Systems, Inc., Oak Ridge Y-12 Plant.

SAIC 1994. Remedial Investigation Report on Bear Creek Valley Operable Unit 2 (Rust Spoil Area, Spoil Area 1, and SY-200 Yard) at the Oak Ridge, Y-12 Plant, Oak Ridge, Tennessee, Vol. 2: Appendixes, DOE/OR/01-1273/V2\&D1, Y/ER-182/V1\&D1, Science Applications International Corporation for Martin Marietta Energy Systems, Inc., Oak Ridge Y-12 Plant. 


\section{DISTRIBUTION}

DEPARTMENT OF ENERGY

P. A. Hoffmann

L. M. Sparks

HEALTH. SAEETY. ENVIRONMENT. AND

ACCOUNTABILITY ORGANIZATION

W. K. Jago

S. B. Jones

L. O. Vaughan

File-GWPP-RC (4)

ENVIRONMENTALRESTORATION PROGRAM

H. L. King

C. S. Walker

D. B. Watson

TDEC/DOE-O

Robert Benfield (3)
UNIVERSITY OF TENNESSEE. KNOXVILLE

B. W. McMaster

ENVIRONMENTAL SCIENCES DIVISION

R. B. Dreier

D. D. Huff

C. T. Rightmire

QRISE

S. M. Field

G. E. Sutton, Jr. (4)

AJA TECHNICAL SERVICES

J. R. Walker

SAIC

W. P. Kegley/D. Moss

CDMFEDERAL PROGRAMS

M. Leslie/C. Lutz

A. K. Lee/DOE-OSTI (2)

Y-12 Central Files 